\title{
AVALIAÇÕES CLÍNICA E MICROBIOLÓGICA DE DISPOSITIVO DE LIBERAÇÃO LENTA DE CLOREXIDINA EM PACIENTES COM PERIODONTITE CRÔNICA
}

\section{FÁBIO LUÍS MOURA LIMA}

Dissertação apresentada à Faculdade de Odontologia de Bauru, da Universidade de São Paulo, como parte dos requisitos para obtenção do título de Mestre em Odontologia, área de Periodontia.

(Edição Revisada)

BAURU

2002 


\section{AVALIAÇÕES CLÍNICA E MICROBIOLÓGICA DE DISPOSITIVO DE LIBERAÇÃO LENTA DE CLOREXIDINA EM PACIENTES COM PERIODONTITE CRÔNICA}

\section{FÁBIO LUÍS MOURA LIMA}

Dissertação apresentada à Faculdade de Odontologia de Bauru, da Universidade de São Paulo, como parte dos requisitos para obtenção do título de Mestre em Odontologia, área de Periodontia.

(Edição Revisada)

Orientador:

Prof. Dr. Sérgio Aparecido Torres

Co-orientador:

Prof. Dr. Sebastião Luiz Aguiar Greghi 
Lima, Fábio Luis Moura

L628 a Avaliações clínica e microbiológica de dispositivo de liberação lenta de clorexidina em pacientes com periodontite crônica / Fábio Luis Moura Lima.

Bauru; 2002.

121p. : il. ; $30 \mathrm{~cm}$.

Dissertação (Mestrado) -- Faculdade de Odontologia de Bauru, USP.

Orientador: Prof. Dr. Sérgio Aparecido Torres

Co-orientador: Prof.Dr. Sebastião Luiz Aguiar Greghi

Autorizo, exclusivamente para fins acadêmicos e científicos, a reprodução total ou
parcial desta dissertação, por processos fotocopiadores e outros meios eletrônicos.
Bauru, 03 de outubro de 2002
Assinatura:




\section{FÁBIO LUIS MOURA LIMA}

11 de maio de 1972

Quixadá-CE

Filiação

1991-1994

1995-1996

1997-1998

1999-2002

Associações
Nascimento

Manoel Pereira Lima

Maria do Socorro Moura Lima

Curso de Graduação em Odontologia pela Universidade Federal do Ceará

Curso de Especialização em Endodontia pela Universidade Federal do Ceará

Curso de Especialização em Periodontia pela Universidade de Santo Amaro, São Paulo-SP

Curso de Pós-graduação em Periodontia, em nível de Mestrado pela Faculdade de Odontologia de Bauru, Universidade de São Paulo

ABO - Associação Brasileira de Odontologia Secção Ceará

SOBRAPE - Sociedade Brasileira de Periodontologia 
A Deus, por tudo que sou e pela força que me faz seguir em frente;

Aos meus pais, Moacir e Moura, que compreenderam os momentos de ausência, me estimulando, sempre com amor, para que eu pudesse atingir esta conquista.

\section{Dedico este trabatho!}




\section{AGRADECIMENTOS ESPECIAIS}

Aos meus pais, Moacir e Moura, pelo amor, pela atenção e renuncia dispensados, conduzindo-me no caminho do dever, da verdade e da honra.

Aos meus irmãos, Márcio e Júlio e minha cunhada Denise pelo constante estímulo dispendido para minha educação e formação.

Aos meus sobrinhos, que mesmo com inocência, mas com carinho, me transmitiram forças para que eu pudesse atingir esse objetivo.

\section{Todo mew amor e gratidão!}


Ao meu orientador, Prof. Dr. Sérgio Aparecido Torres, pelos ensinamentos transmitidos e por dedicar seu tempo a este trabalho, sempre com objetividade e clareza de opinião.

Ao Professor e Co-orientador, Dr. Sebastião Luiz Aguiar Greghi, pela presteza e simpatia dedicadas a mim nos ensinamentos sobre Periodontia, por ter me orientado na realização deste trabalho, assim como pelo excelente clima de amizade e pela maneira acolhedora com que fui sempre tratado.

\section{Minha sincera gratidão!}


Estendo minha eterna gratidão

Aos Prof. Dr. Euloir Passanezi, pelos ensinamentos transmitidos durante o curso, pelas portas abertas, pelo carinho, pela amizade e confiança dispensada.

Ao Prof. Dr. Deoclécio Nahás (in memoriam) pelos ensinamentos valiosos para a minha formação e crescimento profissional.

Ao Prof. Dr. Wilson Roberto Sendyk, pelo modo cordial e gentil com que sempre me tratou, por seu apoio, estímulo e incentivo que sempre foram constantes e presentes e que além de mestre, é sem dúvida um grande amigo. 


\section{AGRADECIMENTOS}

À Prof.Dra. Odila, pelo carinho, carisma, simpatia, amizade e por ter aberto todas as portas da Disciplina de Microbiologia o que facilitou muito a realização deste trabalho;

Ao Prof. Dr. Alberto Consolaro por todo o aprendizado que sem dúvida contribuiu para meu engrandecimento profissional;

À Prof. Dra. Denise e Prof. Dra. Vanessa por terem me recebido sempre com carinho e simpatia na Disciplina de Patologia;

Ao Prof. Dr. José Roberto Pereira Lauris pela realização da análise estatística e por ter sido sempre cordial em todos os momentos que foi solicitado;

Aos colegas do curso de mestrado, Marinelle, Elonice, Ana Claudia, Flávio, Caio, Luciana, Renata, Leonardo, Fábio Valverde, Patrícia e Pedro pelos bons momentos que tivemos juntos e pela convivência enriquecedora;

Aos funcionários da Disciplina de Periodontia, Ivânia, Neusa, Edilaine e Marcos pelo auxílio e convívio agradável;

Aos funcionários da Disciplina de Microbiologia, André, Dalva e Osnir pela atenção, pelo carinho e pela ajuda.

Aos funcionários da Disciplina de Patologia, Bernadete , Cristina , Fátima e Valdir, pela disponibilidade e pela atenção;

Meu carinho e muito obrigado! 


\section{AGRADECIMENTOS}

Às minhas amigas Marinelle, Elonice e Maria do Carmo que com suas palavras de incentivo muitas vezes ajudaram a superar as carências familiares e dificuldades encontradas no decorrer deste curso, pela solidariedade que sempre nos uniu e pela valiosa amizade;

À minha amiga Ivânia pelo apoio, compreensão e incentivo em seguir sempre de cabeça erguida, driblando todas as dificuldades por mim encontradas durante o período que passei em Bauru;

Ao meu amigo André que me ajudou em muito na realização da parte experimental deste trabalho;

À Dalvinha, pessoa de um imenso coração, que nunca mediu esforço em ajudar-me, obrigado pela atenção,apreço e imenso carinho;

Aos amigos Aline, José Francisco e Serginho, por terem mostrado o sentido de uma verdadeira amizade ;

À Jussara e sua filhinha Júlia, pelo apoio, disponibilidade, imenso carinho, e pela maneira carinhosa como me acolheram;

Aos meus amigos doutorandos, Maria do Carmo, Ana Lúcia Nahas, Adriana Passanezi, Damé, Daniel Rezendi, Mônica Dourado, Vinícios e Sung por tudo que compartilhamos, pela troca de conhecimentos e pelos bons momentos que passamos juntos;

Aos amigos Mariana, Carlinha, Martinha, Fabrício, Milena, Stefano pelos bons momentos que passamos junto e pela troca de conhecimentos que sem dúvida favoreceu o meu crescimento profissional;

Meu carinho e muito obrigado! 


\section{AGRADECIMENTOS}

Aos estagiários André Sakima, Cesar, Sérgio, Samara Bonfanti, Estevan Bonfanti e Patrícia lonara por terem me ajudado a realizar o tratamento periodontal dos pacientes que participaram deste estudo;

Aos amigos de toda hora, Maria José, Antônio Carlos, Guilherme, Antônio Luis, Márcia de Luca e Rosângela pelos conselhos, pelo carisma, pelos laços de amizade, pela confiança e oportunidades e por terem suprido minhas carências familiares;

Aos meus amigos Adalberto, Caio, Henri, Jader, João Neto, Marcelo e Saul pelo companheirismo, pela valiosa amizade e por terem compartilhado excelentes momentos de minha vida;

Aos funcionários da Biblioteca pela atenção oferecida sempre que solicitado, em especial a Cibele, Rita, Valéria e Vera;

Aos funcionários da Sessão de Pós-Graduação pelos estimáveis auxílios prestados, em especial à Giane e ao Aurélio.

Aos funcionários do Setor de Triagem da FOB-USP, pelo carinho e atenção;

Aos funcionários da reprografia da Biblioteca, em especial ao Salvador e a Joice, pelos prestes sempre que solicitados;

Aos funcionários do biotério da FOB-USP pelo auxílio na coleta de sangue dos carneiros, tornando possível à realização dos procedimentos laboratoriais;

Meu carinho e muito obrigado! 


\section{AGRADECIMENTOS}

Aos pacientes, pela compreensão e disponibilidade em participar deste trabalho;

A todos que de uma forma anônima e silenciosa contribuíram na elaboração deste trabalho.

Meu carinho e muito obrigado! 


\section{AGRADECIMENTOS INSTITUCIONAIS}

Ao Departamento de Prótese da Faculdade de Odontologia de Bauru, Universidade de São Paulo.

Ao Departamento de Ciências Biológicas da Faculdade de Odontologia de Bauru, Universidade de São Paulo.

À Direção da Faculdade de Odontologia de Bauru, Universidade de São Paulo, na pessoa da Diretora Prof. Dra. Maria Fidela de Lima Navarro.

À Comissão de Pós-Graduação da Faculdade de Odontologia de Bauru, Universidade de São Paulo, na pessoa do Presidente Prof. Dr. José Carlos Pereira.

À CAPES, pelo auxílio que foi indispensável na realização deste trabalho

\section{Muito obrigado!}




\section{SUMÁRIO}

RESUMO $\quad x$

1 INTRODUÇÃO 1

2 REVISÃO DA LITERATURA 6

2.1 O papel dos microrganismos na etiopatogenia da doença periodontal 7

2.2 Sistemas de liberação local de antimicrobianos $\quad 24$

3 PROPOSIÇÃO 41

4 MATERIAL E MÉTODOS 43

$\begin{array}{lll}5 & \text { RESULTADOS } & 72\end{array}$

6 DISCUSSÃO $\quad 89$

7 CONCLUSÕES 109

$\begin{array}{ll}\text { ANEXOS } & 112\end{array}$

$\begin{array}{ll}\text { REFERÊNCIAS BIBLIOGRÁFICAS } & 118\end{array}$

$\begin{array}{lr}\text { ABSTRACT } & 127\end{array}$ 


\section{RESUMO}

A periodontite crônica é resultado de uma infecção por microrganismos patogênicos, na qual a microbiota subgengival juntamente com outros fatores modificadores da resposta biológica do hospedeiro participam da etiologia da doença periodontal. A alteração ou remoção da microbiota patogênica é crucial para o controle da doença, tendo sido sugerido vários agentes antimicrobianos como coadjuvantes à terapia mecânica no tratamento da doença periodontal crônica, entre eles a clorexidina. Este estudo avaliou a eficiência de um dispositivo de liberação lenta contendo clorexidina $(2,5 \mathrm{mg})$ como coadjuvante à raspagem e alisamento radicular no tratamento de periodontite crônica. Foram selecionados dez pacientes com bolsas periodontais bilaterais com profundidade de sondagem entre 5 e $8 \mathrm{~mm}$. Análises microbiológicas foram realizadas no início, dez, 40 e 70 dias após a instrumentação periodontal (sítio controle) e desta associada à colocação de pastilhas de clorexidina (sítios teste). Avaliação clínica através dos parâmetros índice de placa, índice gengival, profundidade de sondagem, recessão gengival e nível de inserção clínica foi realizada no início e após 70 dias. Não se verificaram diferenças estatisticamente significantes entre os sítios analisados e o emprego da pastilha de clorexidina associado à terapia mecânica não mostrou resultados clínicos e microbiológicos expressivos quando comparado somente com a remoção do biofilme gengival. 
1 INTRODUÇÃO 


\section{INTRODUÇÃO}

A doença periodontal pode ser considerada de natureza multifatorial, sendo que as bactérias exercem um papel crucial em sua etiopatogenia ${ }^{4,13,22,42,53,76,80}$. Durante o período que foi considerado a "época de ouro da Microbiologia", aproximadamente entre 1890 e 1920, foram determinados vários agentes etiológicos de importantes infecções. Nessa época, iniciaram-se investigações sobre a etiologia da doença periodontal, sendo sugerida a associação de agentes etiológicos tais como ameba, espiroquetas, fusiformes e estreptococos com as lesões periodontais. É sabido que existe associação entre agentes etiológicos específicos com a doença periodontal e que são propostas diferentes terapias direcionadas para o controle destes microrganismos. Apesar do reconhecimento que a doença periodontal é uma infecção e que o tratamento deveria ser direcionado para os agentes causais, os resultados foram considerados inapropriados, possivelmente, devido à identificação de agentes etiológicos incorretos, aplicação de terapia inadequada e a multiplicidade de doenças. Entre 1920 e 1940, a etiologia da doença periodontal foi atribuída a algum defeito constitucional do paciente, à oclusão traumatogênica, atrofia por desuso ou por uma combinação desses fatores. As bactérias foram consideradas como meros invasores secundários no processo ou no máximo por contribuir na inflamação observada na destruição do periodonto. No final da década de 50, as bactérias voltaram a ter um papel importante na etiologia da doença periodontal, mas como agente causal não específico. Surgiu assim a hipótese da placa não específica, na qual o acúmulo de microrganismos próximos à margem da gengiva marginal produziriam produtos metabólitos irritantes que causavam a inflamação ${ }^{67}$ Em 1965, LOE et al. $^{42}$ 
impulsionaram a hipótese da placa inespecífica através de um estudo clássico no qual demonstraram que o acúmulo de placa bacteriana induzia o desenvolvimento da gengivite. Microrganismos específicos que se acumulavam nos dentes não foram considerados particularmente importantes, mas o aumento do número de microrganismos era suficiente para iniciar o processo de destruição periodontal ${ }^{67}$.

O reconhecimento de diferenças na composição da placa bacteriana de paciente para paciente e de sítio para sítio em um mesmo indivíduo culminou em tentativas para determinar se microrganismos específicos poderiam ser encontrados em sítios com lesão periodontal em comparação com sítios sadios do periodonto, além de investigarem a presença de microrganismos na placa subgengival de pacientes com diferentes formas clínicas de doença periodontal $^{68}$, sugerindo o conceito da placa específica.

Alguns questionamentos não conseguiam ser explicados com base na hipótese da placa inespecífica, por exemplo, se a placa era o ponto inicial para a destruição periodontal, por que certos pacientes que acumulavam muita placa, freqüentemente apresentavam gengivite, mas não desenvolviam destruição periodontal? Por outro lado, por que alguns indivíduos que clinicamente apresentavam pouca placa detectável ou inflamação gengival clínica desenvolviam rápida destruição periodontal ${ }^{67}$ ?

O conceito de periodontite como uma doença caracterizada por períodos de exacerbações e remissões de um processo ativo sugere que variações nas respostas do hospedeiro podem ocorrer durante esses intervalos ${ }^{10}$.

A cavidade bucal alberga uma comunidade microbiana diversa que é encontrada na superfície dos dentes, imersa numa matriz de polímeros de origem bacteriana e salivar, denominada por placa dental ou biofilme ${ }^{51}$, cuja 
presença tem sido associada com a etiologia e progressão da cárie dentária e da doença periodontal. Mais de 350 diferentes microrganismos colonizam a cavidade bucal, entretanto MOORE ${ }^{54}$, em 1987, detectou até 40 espécies de bactérias em um sítio afetado periodontalmente. Apesar desta grande variedade e diversidade, somente algumas espécies têm sido encontradas repetidamente em altos números nos sítios periodontais alvos e, dentre estas podemos citar Actinobacillus actinomycetemcomitans, Porphyromonas gingivalis, Prevotella intermedia, Bacteroides forsythus, Treponema denticola, Peptostreptococcus micros, Eikenella corrodens, Selenomonas spp., Capnocytophaga spp ${ }^{14}$.

A doença periodontal (especificamente a periodontite do adulto) é decorrente de alterações anatômicas (bolsas periodontais) que propiciam um ambiente que favorece a implantação e o desenvolvimento de uma microbiota patogênica, sendo a maior ou menor intensidade da destruição dos tecidos periodontais relacionada com a resposta produzida pelo hospedeiro, que envolve tanto os fatores inespecíficos quanto os específicos. É indiscutível a participação de microrganismos na etiologia das periodontites ${ }^{9,58,66,68}$ e, embora os procedimentos de raspagem e de alisamento radicular sejam fundamentais para a remoção desta microbiota, algumas vezes devido ao difícil acesso a essas áreas não se consegue a eliminação mecânica dessas bactérias e, em alguns sítios, não há como impedir a progressão da doença ${ }^{28}$.

Alguns agentes antimicrobianos foram sugeridos como coadjuvantes à terapia mecânica: clorexidina, doxiciclina, fluoreto, metronidazol, minociclina, sanguinarina e tetraciclina, os quais poderiam ser utilizados através de irrigação subgengival ou através da inserção de dispositivos que promovem a liberação lenta de substâncias nas bolsas periodontais ${ }^{46}$. 
Assim, foram desenvolvidos dispositivos que permitem o estabelecimento e manutenção de concentrações efetivas do medicamento nestes sítios, sobrepondo a ação do fluído gengival ${ }^{30,33}$, a fim de eliminar os efeitos colaterais do uso sistêmico dessas drogas.

GREENSTEIN et al. ${ }^{18}$, em 1986, ao revisarem publicações sobre a clorexidina, concluíram que sua aplicação seria auxiliar na terapia periodontal. Essa substância é empregada na forma de gluconato de clorexidina, cuja fórmula é $\mathrm{C}_{22} \mathrm{H}_{30} \mathrm{Cl}_{2} \mathrm{~N}_{10} \cdot 2 \mathrm{C}_{6} \mathrm{H}_{2} \mathrm{O}_{7}$ e que recebe a denominação química de 1,1-bis-hexametileno(5p-clorofenil biguanida) di D-gluconato. No Brasil, está sendo indicado o PerioChip ${ }^{\circledR}$, um dispositivo que libera clorexidina à medida que ocorre a sua biodegradação no interior da bolsa periodontal. Essa substância apresenta amplo espectro contra os principais microrganismos patogênicos periodontais e diversos estudos têm demonstrado ser um excelente coadjuvante aos procedimentos de raspagem e alisamento radicular no tratamento de periodontite do adulto, com resultados superiores à conduta convencional ${ }^{32,34,39,70}$.

Baseado nestes aspectos, o objetivo desta pesquisa foi comparar a ação da raspagem e do alisamento radicular e a associação da colocação de pastilha de clorexidina (PerioChip $®)$ a esses procedimentos, em pacientes com periodontite crônica, por meio da análise clínica e microbiológica destes sítios. 
2 REVISÃO DE LITERATURA 


\section{REVISÃO DE LITERATURA}

\subsection{O papel dos microrganismos na etiopatogenia da doença periodontal}

A importância da presença da placa bacteriana para o desenvolvimento da gengivite foi demonstrada por LÖE et al. ${ }^{41}$, em 1965 , ao realizarem um estudo clínico em 12 indivíduos nos quais o acúmulo de placa bacteriana ao longo da margem gengival demonstrou íntima relação com a inflamação gengival. Até 21 dias após o início da experiência, a gengivite havia se instalado em todos os pacientes. Também foi verificado durante todo o período experimental que a microbiota passou de uma composição relativamente simples a uma composição complexa. Ainda observaram que com o retorno dos procedimentos de higiene bucal, a gengiva voltou a ser saudável, sem nenhuma seqüela e que principalmente cocos, passaram a compor novamente a microbiota.

Baseados nos dados experimentais do estudo anterior, LÖE et al. ${ }^{42}$ em 1967, investigaram se mudanças na composição bacteriana da placa poderiam influenciar o desenvolvimento da gengivite. Para isto realizou-se uma experiência clínica com 12 indivíduos divididos em quatro grupos. Durante cinco dias a higiene bucal foi suspensa e cada grupo realizou bochechos diários com água destilada e diferentes antibióticos locais (tetraciclina, vancomicina, polimixina B). Foram observadas variações consideráveis na composição da placa entre os diferentes grupos de antibióticos. No grupo que realizou bochechos com água verificou-se um aumento da porcentagem de bactérias Gram-negativas, no grupo da tetraciclina observou-se uma redução do número de microrganismos, com predominância de $\operatorname{cocos}$ e bastonetes Gram-positivos, no grupo da 
polimixina B verificou-se uma proliferação de cocos e bastonetes Grampositivos e diminuição de bactérias Gram-negativas e no grupo da vancomicina foi evidente o aumento de $\operatorname{cocos}$ e bastonetes Gramnegativas, filamentosos e fusiformes. Entretanto, a gengivite clínica não foi observada em nenhum dos indivíduos.

Ao fazer uma revisão de literatura, SOCRANSKY ${ }^{64}$, em 1970, constatou que todas as formas de doenças periodontais em humanos são provavelmente de etiologia bacteriana, onde mais de um tipo de microrganismos presente no sulco gengival poderia iniciar a destruição periodontal, sugerindo a possibilidade de que a doença periodontal fosse decorrente da habilidade de um ou mais microrganismo se acumular na placa ser um pré-requisito para o início da destruição do periodonto, entretanto, esse mecanismo ainda não estava claro.

Ainda no mesmo ano, $\mathrm{BAHN}^{4}$ atribuiu aos microrganismos da placa subgengival o principal fator etiológico da doença periodontal e sua progressão poderia ser alterada por algumas situações como: irritantes físicos, trauma oclusal, doenças sistêmicas, defeitos genéticos, alterações hormonais e desordens nutricionais que promoveriam a quebra do equilíbrio entre as bactérias e as defesas do hospedeiro.

De acordo com SNYDERMAN ${ }^{63}$, em 1972, a destruição dos tecidos periodontais seria resultante do processo inflamatório em resposta às defesas do hospedeiro, e os microrganismos seriam responsáveis por desencadear esse processo, com a liberação de seus produtos tóxicos, como as endotoxinas. A interação das endotoxinas com o complemento resultaria 
na liberação de produtos ativos que induziriam a permeabilidade vascular, contração da musculatura lisa, degranulação dos mastócitos e quimiotaxia dos neutrófilos e macrófagos. A reação inflamatória promoveria a liberação de células inflamatórias, produtos intracelulares, tais como histamina, heparina e potentes enzimas lisossomais proteolíticas que por sua vez mediariam a destruição do periodonto iniciada pelas endotoxinas bacterianas.

LINDHE et al. ${ }^{38}$, em 1973, associaram a presença de placa bacteriana e os mecanismos de defesa do hospedeiro com a destruição dos tecidos de sustentação dos dentes, ao realizarem um estudo em 20 cães Beagles que foram alimentados com o mesmo tipo de dieta. Estes foram divididos em dois grupos: controle, cujos dentes inferiores esquerdos foram limpos duas vezes ao dia e experimental, nos quais os referidos dentes não foram limpos. Os cães foram examinados no início e após 7, 14, 21 e 28 dias e $2,4,6,8,12$ e 18 meses. Verificou-se que a placa bacteriana rapidamente iniciou-se nos dentes do grupo experimental, já no grupo controle a presença de placa só foi observada ocasionalmente. A íntima relação entre o acúmulo de placa bacteriana, exsudato gengival e migração de leucócitos creviculares durante as primeiras três semanas nos dentes do grupo experimental sugeriu a presença de fatores dentro da placa bacteriana capazes de induzir as alterações inflamatórias. Além disso, nesse grupo, foi observado aumento na profundidade de sondagem e reduzida densidade óssea em áreas interproximais de alguns dentes após 18 meses. No grupo controle, não se observaram significantes alterações no índice gengival, no número de leucócitos creviculares, na profundidade de sondagem e nem perda de inserção. 
KELSTRUP; THEILADE ${ }^{29}$, em 1974, acreditavam que toda doença periodontal seria iniciada como uma gengivite que eventualmente evoluiu para uma periodontite caracterizada por inflamação, formação de bolsas e perda de osso alveolar. Assim, a placa bacteriana através do sulco e epitélio juncional induziria a emigração e acúmulo dos leucócitos polimorfonucleares no tecido conjuntivo. A hiperemia e proliferação vascular produziriam edema e mudança de cor que são os primeiros sinais clínicos da inflamação. Substâncias citotóxicas bacterianas, linfocinas, provavelmente afetariam a capacidade dos fibroblastos em manter a formação de fibras colágenas. Também acreditavam existir uma forte e positiva relação entre a severidade da doença com o acúmulo de placa, cálculo e com a idade, além de proporem que as bactérias da área do sulco fossem alvo de mais estudos.

Para SOCRANSCKY ${ }^{65}$, em 1977, existiam evidências suficientes de que as bactérias desempenhavam uma função primária na etiologia da doença periodontal; entretanto, os microrganismos específicos relacionados com as diferentes formas da doença deveriam ser identificados e a microbiota das áreas afetadas controlada, eliminando-se as bactérias patogênicas, antes do início da destruição dos tecidos periodontais.

LINDHE et al. ${ }^{37}$, em 1980, realizaram um estudo em 22 pacientes com idades entre 21 e 28 anos, nos quais seis áreas do periodonto foram selecionadas e divididas de acordo com os sinais clínicos, para avaliar a microbiota de bolsas periodontais e as características histopatológicas dos tecidos vizinhos a áreas saudáveis e com doença. Através da análise bacteriológica verificaram que as proporções de bactérias nas amostras 
foram bastante diferentes entre as várias categorias clínicas, sendo que nas áreas saudáveis havia poucos microrganismos, dos quais $\operatorname{cocos} \mathrm{e}$ bastonetes predominavam, enquanto que na presença da doença avançada, era comum um grande número de espiroquetas. Nos locais com gengivite, encontraram-se principalmente cocos, bastonetes filamentos e fusiformes. Observaram um aumento na complexidade da microbiota com o aumento da severidade da doença e, através de biópsia, verificaram que a composição celular do infiltrado inflamatório do tecido conjuntivo estava de alguma maneira correlacionada com a composição da população bacteriana.

SLOTS; GENCO ${ }^{62}$, em 1984, ressaltaram a função dos produtos de bactérias específicas na etiologia da doença periodontal, pois, apesar de ser um processo complexo e ainda não muito bem esclarecido, a presença desses metabólitos seria fundamental na etiopatogenia da doença, e dentre as bactérias periodontopatogênicas, o Actinobacillus actinomycetemcomitans e a Bacteroides gingivalis, apresentavam maior virulência por estarem associadas com áreas de destruição periodontal. Também ressaltaram que bactérias poderiam invadir os tecidos periodontais subepiteliais pelo menos nas formas mais severas de periodontite.

Para SLOTS; DAHLÉ ${ }^{61}$, em 1985, Bacteroides gingivalis, Bacteroides intermedius e Actinobacillus actinomycetemcomitans seriam importantes periodontopatógenos, sendo que os fatores de virulência dos dois primeiros poderiam envolver principalmente enzimas com potencial de interferir com as defesas do hospedeiro e de promover destruição dos 
tecidos periodontais. O Actinobacillus actinomycetemcomitans agiria pela produção de toxinas que atuariam contra as células de defesas do hospedeiro, estando mais associado a periodontites avançadas em indivíduos jovens. Foi ressaltado que os Bacteroides gingivalis e Bacteroides intermedius seriam importantes microrganismos em muitos casos de periodontite do adulto.

Segundo PAGE ${ }^{55}$, em 1986, a etiologia da doença periodotal crônica depende de microrganismos, sendo predominantes nas bolsas periodontais os Gram negativos, anaeróbios e móveis, principalmente Bacteroides gingivalis, Bacteroides intermedius, Fusobacterium nucleatum e Eikenella corrodens. Além disso, fatores ambientais locais por aumentarem o acúmulo e a retenção de placa bacteriana e a resposta do hospedeiro frente a estes microrganismos, deveriam ser levados em consideração na etiologia da doença periodontal.

MAC FARLANE et al. ${ }^{44}$, em 1988, avaliaram clínica e microbiologicamente 11 indivíduos durante um ano. Foram coletadas amostras de placa subgengival para análise da porcentagem de espiroquetas e de espécies de bacteróides de pigmentação negra. Verificaram que a mudança no nível de inserção não foi dependente da porcentagem inicial de espiroquetas ou de bacteróides. Além disso, observaram que não houve diferença entre os sítios testes e os controles, no que diz respeito aos dados microbiológicos. Eles sugeriram que a quantificação desses microrganismos não poderia ser usada para identificar ou predizer áreas com destruição ativa de doença periodontal. 
Para MAIDEN et al. ${ }^{48}$, em 1990, a destruição periodontal resultaria de um desequilíbrio na imunidade e de uma resposta não específica à microbiota desse indivíduo. Acreditavam que a etiologia da doença periodontal estaria relacionada com uma microbiota específica, porém, ainda não era possível separar as mudanças dessa microbiota dentro das causas e efeitos de uma fase particular da doença periodontal. Eles também sugeriram que indivíduos com alto risco de desenvolver a doença pudessem ser identificados por diferenças na microbiota subgengival quando comparados com indivíduos de baixo risco.

SBORDONE et al. ${ }^{59}$, em 1990, avaliaram o padrão de recolonização da microbiota subgengival de oito pacientes com periodontite do adulto submetidos a uma sessão de raspagem e alisamento radicular e sem instrução de higiene bucal, através de parâmetros clínicos e microbiológicos, obtidos antes da realização deste procedimento e após 7 , 21 e 60 dias. Uma melhora na profundidade de sondagem ocorreu após 60 dias, entretanto não houve mudanças marcantes em relação ao índice gengival. A análise da microbiota dos sítios tratados após sete dias da terapia foi similar aos sítios saudáveis, quando avaliado por exames bacterioscópico e bacteriológico. Após 21 dias, a microscopia de campo escuro demonstrou o predomínio de cocos e poucas espiroquetas enquanto as culturas indicaram que a maioria dos cocos era composta por Peptostreptococcus micros e Veillonella parvula. Decorridos 60 dias, não houve variação significante em nenhum dos parâmetros em relação ao prétratamento. Foi verificado que as bactérias anaeróbias: Fusobacterium nucleatum, Bacteoides gingivalis e Bacteroides intermedius foram as espécies prevalentes antes e após os procedimentos de raspagem e 
alisamento radicular. Os autores observaram divergência entre os resultados da microscopia de campo escuro, cultura microbiológica e inflamação gengival e sugeriram que o exame bacteriológico por campo escuro foi inadequado para identificar uma microbiota patogênica. Concluíram que uma sessão de raspagem e de alisamento radicular, na ausência de instrução de higiene bucal, seria insuficiente para restituir uma microbiota saudável.

Para MARSH ${ }^{49}$, em 1991, a formação da placa bacteriana seria um processo dinâmico, assim sua deposição, crescimento e remoção seria um processo contínuo e sua estrutura seria submetida à constante reorganização. Também salientou que a maioria das espécies bacterianas presentes na placa seria facultativa ou anaeróbios estritos. Uma pobre higiene bucal poderia resultar em acentuado acúmulo de placa no sulco gengival, promovendo uma resposta inflamatória do hospedeiro e um aumento no fluxo do fluido gengival que contém tanto componentes de defesas do hospedeiro como peptídeos, glicoproteínas e proteínas que poderiam servir como nutrientes para as bactérias. Esta mudança no padrão de nutrientes poderia favorecer o crescimento de microrganismos obrigatoriamente anaeróbios, bactérias Gram-negativas, como por exemplo, Fusobacterium, Porphyromonas, Prevotella e Treponemas ssp, que estão relacionados com a destruição periodontal.

SOCRANSKY; HAFFAJEE ${ }^{66}$, em 1992, observaram inúmeros trabalhos na literatura relacionando certas bactérias subgengivais com a destruição do periodonto, tais como Actinobacillus actinomycetemcomitans, Porphyromonas gingivalis, Prevotella intermedia, 
Fusobacterium nucleatum, Bacteroides forsythus, Campylobacter rectus, Eikenella corrodens, Peptostreptococus micros, Streptococcus intermedius e espiroquetas. Também salientaram que esses microrganismos eram encontrados em maior número e frequiência em áreas ativas da doença quando comparadas com áreas inativas.

De acordo com MARSH $^{50}$, em 1992, as bactérias associadas à doença periodontal produziam enzimas que poderiam destruir diretamente os tecidos ou interferir com a atividade das defesas do hospedeiro. A resposta do hospedeiro frente a essa agressão resultaria em uma inflamação que poderia promover a destruição tecidual devido à liberação de enzimas proteolíticas de células fagocitárias e outras células do hospedeiro. Uma grande variedade de agentes antimicrobianos poderia ser utilizada para o controle da placa bacteriana, entretanto poucos desses agentes seriam efetivos por causa da falta de compatibilidade com as formulações dos produtos dentários ou pela eficácia clínica deficiente. Ele também salientou que o efeito dos antimicrobianos sobre a placa bacteriana seria dependente da concentração do agente liberado no sítio e que os agentes poderiam estar presentes inicialmente em uma concentração relativamente alta, mas somente por um curto período de tempo. Além disso, em alta concentração, um agente poderia ser bactericida e reduzir os níveis salivares ou na placa de um microrganismo, promovendo a destruição das bactérias. Já em baixa concentração, o agente seria bacteriostático e os microrganismos permaneceriam viáveis, mas não se multiplicariam e, neste caso, o agente seria efetivo por reduzir a produção de citotoxicinas ou de enzimas proteolíticas. 
WOLFF et al. ${ }^{80}$, em 1993, realizaram um estudo utilizando imunofluorescência para determinar a prevalência e distribuição de cinco bactérias associadas com doença periodontal: $P$. gingivalis, $A$. actinomycetemcomitans, P. intermedia, E. corrodens e F. nucleatum. Amostras de placa subgengival foram coletadas de 6905 sítios em 983 pacientes com gengivite ou periodontite. Foi encontrada uma prevalência de $32 \%, 38 \%, 42 \%, 49 \%$ e $35 \%$ de $P$. gingivalis, $A$. actinomycetemcomitans, P. intermédia, E. corrodens e F. nucleatum, respectivamente. Houve uma relação direta entre os níveis destes patógenos e a profundidade de sondagem.

KOJIMA; YASUI; ISHIKAWA ${ }^{35}$, em 1993, avaliaram o papel das Porphyromonas gingivalis na patogenia da doença periodontal, através da análise da placa subgengival de quatro sítios de todos dentes remanescentes de 12 pacientes com periodontite do adulto. A amostra de placa foi avaliada através do uso de uma sonda de DNA para $P$. gingivalis e a quantidade destas bactérias foi estatisticamente comparada com a profundidade de sondagem e sangramento à sondagem em cada paciente. Constatou-se que o patógeno representava $35 \%$ de todas as amostras, sendo que nos locais com profundidade de sondagem menor que $3 \mathrm{~mm}$ a detecção de $P$. gingivalis foi extremamente baixa e quando a profundidade de sondagem foi maior que $4 \mathrm{~mm}$ ou com sangramento durante a sondagem houve um aumento significante de $60 \%$ para $80 \%$. Entretanto, essa bactéria fora também detectada em sítios clinicamente saudáveis e não fora detectada em sítios doentes em alguns pacientes, indicando que $P$. gingivalis apresentava um papel importante, mas não era o único responsável pela periodontite do adulto. 
SOCRANSCKY; HAFFAJEE ${ }^{67}$, em 1994, advogaram que a presença de patógenos periodontais seria necessária, mas não o suficiente para que ocorra a doença, pois, outros fatores como a susceptibilidade do hospedeiro, a interação entre espécies de microrganismos e o ambiente da bolsa, seriam importantes para facilitar a progressão da doença e a expressão de propriedades virulentas das bactérias.

Segundo WOLFF; DAHLÈN ; AEPPLI ${ }^{79}$, em 1994, os patógenos periodontais freqüentemente isolados de indivíduos com periodontite severa, embora habitassem o ambiente subgengival não estavam sempre associados com doenças avançadas. A susceptibilidade do hospedeiro e condições ambientais locais que aumentem a susceptibilidade, associados a fatores bacterianos, poderiam ser necessários para a progressão da doença periodontal. Assim, em um indivíduo no qual a resposta do hospedeiro é comprometida geneticamente (por exemplo, defeitos na função dos neutrófilos) e/ou ambientalmente (por exemplo, fumante, pobre higiene bucal), $P$. gingivalis e/ou outras bactérias podem promover a perda de inserção nos sítios com periodontite.

GROSSI et al. ${ }^{19}$, em 1994, avaliaram 1426 indivíduos com 25 a 74 anos de idade com o objetivo de estabelecer uma relação positiva entre idade, fumo, doenças sistêmicas, riscos ocupacionais e microbiota subgengival como indicadores de risco à perda de inserção periodontal, e através da imunofluorescência, investigaram a ação de vários microrganismos, tais como Actinobacillus actinomycetemcomitans, Bacteroides forshytus, Campylobacter rectus, espécies de Capnocytophaga, Eubacterium saburreum, Fusobacterium nucleatum, 
Porphyromonas gingivalis e Prevotella intermedia. Foi verificado que dentre os microrganismos avaliados, apenas a percentagem de Porphyromonas gingivalis e de Bacteroides forshytus mostrou um aumento estatisticamente significante com os diferentes níveis de inserção, enquanto que espécies de Capnocytophaga não foram associadas com a perda de inserção.

Estes mesmos autores ${ }^{20}$, em 1995, realizaram um estudo em 1361 indivíduos com o objetivo de investigar as bactérias subgengivais como possíveis indicadores de risco à perda óssea alveolar associada a doença periodontal. Foram obtidas dez radiografias intraorais, sendo quatro radiografias interproximais dos dentes posteriores e seis radiografias periapicais dos dentes anteriores. As imagens das radiografias foram capturadas com uma câmera e observadas em um monitor. Um conjunto de "software" foi utilizado para determinar a distância entre a junção cemento-esmalte e a crista do osso alveolar. As amostras da placa subgengival foram analisadas utilizando microscopia de imunofluorescência para os seguintes microrganismos: Actinobacillus actinomycetemcomitans, Bacteroides forsythus, Campylobacter rectus, Capnocytophaga sp, Eubacterium saburreum, Fusobacterium nucleatum, Porphyromonas gingivalis e Prevotella intermedia. Observou-se uma correlação positiva entre a perda óssea alveolar e a colonização subgengival de Bacteroides forsythus e Porphyromonas gingivalis, ocorrendo uma perda de $95 \%$ a mais nos sítios onde estas bactérias estavam presentes quando comparados aos sítios nos quais elas estavam ausentes. 
ALPAGOT et al. ${ }^{2}$, em 1996, realizaram um estudo transversal em 117 indivíduos de raças diferentes com o intuito de avaliar fatores de risco à doença periodontal através de amostras do fluido gengival e da placa subgengival. Os resultados mostraram que a Porphyromonas gingivalis estava significantemente relacionada com a perda de inserção, enquanto que a Prevotella intermedia e o Fusobacterium nucleatum estavam associados com a profundidade de sondagem, podendo desta forma, serem possíveis indicadores de risco à doença periodontal.

ELLWOOD et al. ${ }^{11}$, em 1997, investigaram a associação de Porphyromonas gingivalis, Prevotella intermedia e Actinobacillus actinomycetemcomitans com parâmetros clínicos registrados em um grupo de 527 adolescentes de várias etnias, sendo que 67\% eram caucasianos, $35 \%$ eram indo-paquistanês e $1 \%$ eram africanos. As porcentagens de indivíduos indo-paquistanês com pelo menos um sítio positivo para $P$. gingivalis, $P$. intermedia e A. actinomycetemcomitans foram 17\%, $2 \%$ e $3 \%$, respectivamente, e para os caucasianos foram $3 \%, 2 \%$ e $4 \%$. Os indopaquistanês foram os que apresentaram pior condição periodontal. A prevalência de $P$. gingivalis foi associada à etnia dos indivíduos, com a presença de cálculo subgengival, sangramento à sondagem e com profundidade de sondagem maior que $3 \mathrm{~mm}$, enquanto a presença de $P$. intermédia foi associada com a presença de placa bacteriana e cálculo subgengival. Nenhuma diferença na prevalência de $A$. actinomycetemcomitans foi encontrada na presença ou ausência dos parâmetros clínicos. 
PAGE $^{56}$, em 1998, salientou a importância do biofilme e da resposta do hospedeiro na etiologia das doenças periodontais. As bactérias presentes no biofilme e seus produtos iniciariam o processo de destruição dos tecidos gengivais e do ligamento periodontal e em conseqüência causariam reabsorção do osso alveolar. $\mathrm{O}$ biofilme conteria numerosos microambientes que variam em $\mathrm{pH}$, tensão de oxigênio e disponibilidade de nutrientes específicos e apresentaria resistência às respostas do hospedeiro, uma vez que os neutrófilos não conseguiriam agir efetivamente em um agregado com mais de cinco bactérias. As bactérias se comunicariam umas com as outras e construiriam uma estrutura complexa com um sistema circulatório primitivo. O fluido gengival contendo complemento e anticorpos, e todos os outros sistemas presentes no sangue para previr e controlar a infecção, fluiriam através da bolsa periodontal continuamente banhando o biofilme. As bactérias seriam em parte protegidas contra a ação de antibióticos administrados local e sistemicamente. Leucócitos, especialmente neutrófilos, se acumulariam na superfície do biofilme. Mesmo assim, as bactérias sobreviveriam e prosperariam. Bactérias Gram negativas presentes liberariam o lipopolissacarídeo (LPS) que ao ganhar acesso ao tecido conjuntivo e vasos sangüíneos através do tecido epitelial acentuariam ainda mais o processo inflamatório.

Segundo GENCO et al. ${ }^{13}$, em 1998, as bactérias exerceriam um papel primário na etiologia das diferentes formas das doenças periodontais inflamatórias, sendo que algumas espécies seriam consideradas significantemente patogênicas e somente poucos tipos clonais dentro de cada espécie poderiam realmente causar a doença. Microrganismos como 
A. actinomycetemcomitans, $P$. gingivalis, $P$. intermédia / nigrescens, $B$. forsythus, Campylobacter rectus, Eubacterium nodatum, Fusobacterium nucleatum, Peptostreptococcus micros, Treponema denticola, Eikenella corrodens, Pseudomonas, Selenomonas e Staphylococcus participariam da etiologia das doenças periodontais. A mera presença de uma ou mais espécies patogênicas não estaria necessariamente associada à progressão da doença, em parte devido à resposta do hospedeiro e em parte devido à interação entre os membros da microbiota bucal, alguns dos quais poderiam promover o crescimento de patógenos primários, enquanto outros poderiam inibir seu crescimento.

Para SOCRANSKY et al. ${ }^{69}$, em 1999, ao enfatizarem a importância do biofilme na etiologia e tratamento das doenças periodontais, o biofilme promoveria inúmeras vantagens para a colonização das espécies bacterianas, uma vez que nutrientes são encontrados em níveis mais elevados em superfícies do que em solução. Os microrganismos que vivem em biofilmes seriam mais resistentes a antibióticos que organismos que vivem na forma planctônica (células livres). A presença de canais possibilitaria a passagem de nutrientes e outras substâncias para os microrganismos localizados nas camadas mais profundas do biofilme, o que possibilitaria sua proliferação nas camadas adjacentes as superfícies sólidas. Além disso, a matriz glicoprotéica do biofilme poderia atuar como uma barreira protegendo contra a ação de antibióticos.

MOMBELLI et al. ${ }^{52}$, em 2000, avaliaram o padrão de distribuição de Porphyromonas gingivalis, Prevotella intermédia/nigrescens e Actinobacillus actinomycetemcomitans, após raspagem e alisamento 
radicular e retalho de Widman modificado em 17 pacientes com periodontite, nos quais as amostras de placa subgengival foram colhidas das faces mesial e distal de todos os dentes. A P. gingivalis foi detectada em uma alta porcentagem dos pacientes (59\%), mas em baixa proporção nos sítios $(5,4 \%)$. A P. intermedialnigrescens só não foi detectada em um paciente, sendo encontrada em 40,6\% dos sítios avaliados e mostrou uma forte relação em sítios com sangramento. $\mathrm{O}$ A. actinomycetemcomitans foi encontrado apenas em cinco pacientes. Os autores concluíram que se após o tratamento mecânico padrão, um grande número de sítios continuassem sangrando, podederia esperar um número elevado de sítios positivos para P. intermedia/nigrescens e nos casos de bolsas profundas persistirem, poderia esperar um maior número de sítios positivos para a $P$. gingivalis.

A presença de Treponema socranskii, Treponema denticola e Porphyromonas gingivalis foi associada com destruição periodontal por TAKEUCHI et al. ${ }^{76}$, em 2001, em um estudo realizado em 123 pacientes, sendo 38 com periodontite agressiva, 65 com periodontite crônica e 20 pacientes saudáveis. Foram avaliadas amostras da saliva e da placa subgengival e os microrganismos foram identificados pela reação de polimerase em cadeia (PCR). Parâmetros clínicos foram relacionados com a presença desses microrganismos e observou-se que a detecção de $T$. socrankii foi de $71.1 \%, 89,2 \%$ e $30 \%$ em amostras de placa subgengival de pacientes com periodontite agressiva, pacientes com periodontite crônica e pacientes saudáveis, respectivamente. O T. denticola foi detectado em $73,7 \%, 93,8 \%$ e $5 \%$ das amostras de placa subgengival de pacientes com periodontite agressiva, periodontie crônica e pacientes saudáveis, respectivamente. A $P$. gingivalis foi encontrada em $84,2 \%, 95,3 \%$ e $10 \%$ 
das amostras de placa subgengival de pacientes com periodontite agressiva, periodontite crônica e pacientes saudáveis, respectivamente. Esses três microrganismos foram detectados freqüentemente em sítios com profundidade de sondagem elevada, perda de inserção avançada e sangramento a sondagem nos pacientes com periodontite agressiva e naqueles com periodontite crônica. O T. denticola foi freqüentemente detectado juntamente com o $P$. gingivalis em amostras de placa subgengival, mostrando alto índice em pacientes com periodontite crônica e periodontite agressiva. Co-infecções de $T$. denticola/P. gingivalis; $T$. socranskii/P. gingivalis; T. socranskiil T. denticola foram freqüentemente encontradas em bolsas com profundidade de sondagem $\geq 7 \mathrm{~mm}$ em pacientes com periodontite agressiva. Também foi observado que o $T$. denticola e $P$. gingivalis mostraram uma detecção semelhante tanto nas amostras de saliva como nas amostras de placa bacteriana, entretanto, a detecção do T. socranskii foi mais baixa nas amostras da saliva do que nas amostras de placa subgengival.

No mesmo ano, HAMLET et al. ${ }^{22}$, mostraram a relação entre o $A$. actinomycetemcomitans, $P$. gingivalis e $P$. intermedia e profundidade de sondagem em 504 indivíduos australianos. Os microrganismos foram detectados em amostras de placa subgengival através do teste ELISA. O total de 6030 amostras de placa subgengival foi analisada, sendo que $40 \%$ dos pacientes apresentaram pelo menos um dos três microrganismos. $\mathrm{O} A$. actinomycetemcomitans, a P.gingivalis e P. intermedia foram detectados em $23 \%, 15 \%$ e $10 \%$ dos pacientes, respectivamente. A prevalência de $A$. actinomycetemcomitans diminuiu com o aumento da profundidade de sondagem, embora isso não tenha sido estatisticamente significante. A 
prevalência de $P$. gingivalis foi fortemente associada a bolsas profundas. Não houve diferenças na prevalência da $P$. intermedia entre sítios com baixa profundidade de sondagem e sítios com profundidade de sondagem intermediaria, sendo que esta bactéria não foi detectada em sítios com profundidade de sondagem $\geq 5 \mathrm{~mm}$.

\subsection{Sistemas de liberação local de antimicrobianos}

De acordo com MAGNUSSON et al. ${ }^{47}$, em 1984, a recolonização da microbiota subgengival após raspagem e alisamento radicular poderia ocorrer lentamente após vários meses, sendo que algumas espécies bacterianas recolonizariam bolsas periodontais profundas após 140 a 224 dias a despeito de múltiplas sessões de instrumentação subgengival e meticuloso controle de placa.

MACALPINE et al. ${ }^{43}$, em 1985, avaliaram 64 sítios com profundidade de sondagem $\geq 6 \mathrm{~mm}$ em 11 pacientes com periodontite crônica, nos quais foram realizados procedimentos de raspagem e alisamento radicular, instrução de higiene bucal e irrigação com clorexidina $2 \%$, tetraciclina $(50 \mathrm{mg} / \mathrm{ml})$, solução salina fisiológica e não realização de irrigação. Os autores verificaram que após 24 semanas, os sítios que foram irrigados a cada duas semanas, apresentaram uma diminuição na profundidade de sondagem, no índice de sangramento, no número de espiroquetas e melhora no índice de inserção, porém não houver diferenças estatisticamente significantes entre os grupos analisados. 
GREENSTEIN; BERMAN; JAFFIN ${ }^{18}$, em 1986, ao descreverem a estrutura, o mecanismo de ação, espectro de atividade e adsorção da clorexidina afirmaram que sua aplicação poderia promover melhoria na terapia periodontal. A clorexidina seria um antimicrobiano de largo espectro e sua fórmula consistiria em dois anéis simétricos de 4-clorofenil e dois grupos de bisguanida conectados por uma cadeia central de hexametileno. O seu efeito bactericida seria devido à ligação entre sua molécula catiônica e as cargas negativas das paredes das células bacterianas, portanto alterando o equilíbrio osmótico dessas células. Quando em baixas concentrações, substâncias de baixo peso molecular escoariam, especificamente fósforo e potássio. Em altas concentrações, ocorreria precipitação do conteúdo citoplasmático resultando na morte celular. A clorexidina seria efetiva contra microrganismos Gram-positivos e Gram-negativos e sua adsorção aos substratos aniônicos (hidroxiapatita, glicoproteínas salivares e membranas das mucosas) lhe confereria uma maior retenção, lenta liberação e conseqüentemente um efeito bactericida mais prolongado. Os autores também afirmaram que o desenvolvimento de cepas resistentes seria um fenômeno freqüentemente associado à terapia com antibióticos, mas isso não fora verificado com a clorexidina.

STABHOLZ et al. ${ }^{73}$, em 1986, avaliaram clínica e microbiologicamente a ação de um dispositivo de liberação lenta a base de etilcelulose contendo clorexidina. Foram selecionados oito pacientes com 13 bolsas periodontais com profundidade de sondagem entre 5 e $8 \mathrm{~mm}$ nos quais tinham sido realizados raspagem e alisamento radicular dois meses antes. O dispositivo foi trocado a cada três dias por um período de nove dias. Após onze semanas da remoção do último dispositivo colocado, foi 
observada uma diminuição acentuada no número total de anaeróbios, de espiroquetas e de bacilos móveis e redução na profundidade de sondagem nos sítios avaliados. Dessa forma, foi demonstrado que a clorexidina poderia ser mantida em concentração efetiva por até 11 semanas.

ADDY et al. ${ }^{1}$, em 1988, compararam o uso de tiras de acrílico contendo diferentes antimicrobianos (clorexidina, metronidazol e tetraciclina) com raspagem e alisamento radicular somente e a não realização de tratamento em 75 pacientes com bolsas periodontais $\geq 6 \mathrm{~mm}$. Antes da colocação das tiras de acrílico, realizou-se raspagem e alisamento radicular nos sítios. As tiras permaneceram nos sítios por uma smana, quando foram colocadas novas tiras, as quais permaneceram por mais sete dias. Profundidade de sondagem, sangramento à sondagem e perda de inserção foram avaliados no início e após 3 meses. No final do estudo, foi verificado que houve melhora clínica para os quatro tipos de tratamentos avaliados, entretanto melhores resultados foram obtidos para o grupo que recebeu somente a terapia mecânica e o grupo que recebeu tiras de acrílico contendo metronidazol.

Segundo GJERMO ${ }^{15}$, em 1989, a atividade antibacteriana da clorexidina apresentaria um espectro amplo, sendo que as bactérias Grampositivas seriam mais susceptíveis que as bactérias Gram-negativas. Microrganismos como o Streptococcus sanguis, por exemplo, apresentariam uma grande variação em relação a susceptibilidade entre várias cepas. Esta variação entre cepas de mesma espécie poderia implicar mudanças na microbiota bucal após prolongado uso de clorexidina. Também ressaltou que a clorexidina, em concentrações relativamente altas, 
seria bactericida por penetrar nas células e promover a precipitação de seu citoplasma. Quando em baixa concentração, a clorexidina apresentaria efeito bacteriostático. A carga positiva das moléculas de clorexidina se uniria prontamente à carga negativa da parede das células o que interferiria com o transporte da membrana e iniciaria o vazamento de substâncias de baixo peso molecular.

STANLEY ; WILSON; NEWMAN ${ }^{75}$, em 1989, avaliaram através de métodos de diluição a susceptibilidade da clorexidina para uma variedade de bactérias que podem ser isoladas da placa subgengival. Foram utilizadas 50 cepas de bactérias de culturas puras bem como 25 amostras de placa subgengival de pacientes com periodontite crônica com o intuito de determinar a concentração inibitória mínima (MIC) capaz de prevenir o crescimento das bactérias em placas. Foi observado que a MIC da clorexidina para culturas puras variou de 8 a $500 \mu \mathrm{g} / \mathrm{ml}$ com valor médio de $62 \mu \mathrm{g} / \mathrm{ml}$ sendo inibido $64 \%$ das cepas. Em relação as amostras da placa subgengival verificou-se que a MIC variou de 31 a $250 \mu \mathrm{g} / \mathrm{ml}$, com o valor médio de $125 \mu \mathrm{g} / \mathrm{ml}$ de clorexidina, capaz de inibir $99 \%$ da microbiota.

Segundo GOODSON ${ }^{16}$, em 1989, o fluido gengival produzido nos sítios com periodontite tem sido reconhecido como um indicador de inflamação, mas não tem sido avaliada sua participação no processo que tende a remover agentes terapêuticos aplicados na bolsa periodontal. Também salientou que o volume total de fluido na bolsa periodontal apresentaria um "turnover" de aproximadamente 40 vezes em uma hora, o que seria mais freqüente que o "turnover" salivar na cavidade bucal, que 
seria de aproximadamente 28 vezes em uma hora, ou seja, as substâncias seriam mais rapidamente eliminadas da bolsa periodontal do que da cavidade bucal.

WADE; ADDY ${ }^{78}$, em 1989, testaram "in vitro" a susceptibilidade de 315 bactérias subgengivais, obtidas de nove pacientes com periodontite crônica, frente a diferentes diluições da solução de gluconato de clorexidina a 0,2\% para bochecho (variou de 1:20 a 1:2560) e concluíram que a solução de clorexidina para bochechos tem potencial para uso subgengival no tratamento deste tipo de periodontite, embora recomendassem outros estudos para confirmar a eficiência do anti-séptico no interior da bolsa periodontal. A maioria dos microrganismos testados foi suscetível a altas diluições de clorexidina, como as espécies de Selenomonas sputigena. Porphyromonas gingivalis, Prevotella intermedia; entretanto as cepas de Fusobacterium nucleatum, Streptococcus sanguis, Streptococcus mitior e Capnocytophaga foram relativamente resistentes.

JOLKOVSKY et al. ${ }^{27}$, em 1990, selecionaram 60 pacientes com pelo menos duas bolsas periodontais com profundidade de sondagem $\geq 4 \mathrm{~mm}$, nas quais foram realizadas raspagem e alisamento radicular. Os pacientes foram divididos em quatro grupos. No grupo I foram feitas irrigação subgengival com clorexidina $0,12 \%$ por um profissional e irrigação caseira na margem gengival com clorexidina $0,04 \%$; no grupo II foram feitas irrigação subgengival com clorexidina $0,12 \%$ por um profissional e irrigação caseira na margem gengival com água; no grupo III foram feitas irrigações com água pelo profissional e pelo paciente e no grupo IV não foram realizadas irrigações (grupo controle). Após três meses foi 
observado não existir diferenças estatisticamente significantes entre os grupos que receberam irrigação, entretanto houve melhoras clínicas nestes grupos. Também observaram que ao comparar as mudanças entre os grupos, o grupo que recebeu tanto irrigação profissional como caseira com clorexidina teve uma redução significante de bastonetes facultativos Gramnegativos.

Para KALDAHL; KALKWARF; PATIL ${ }^{28}$, em 1993, a meta dos tratamentos convencionais contra a periodontite seria bloquear ou ao menos retardar a progressão da doença que resulta na destruição dos tecidos de suporte do dentes. A conduta mecânica de raspagem e alisamento radicular seria a principal forma empregada em periodontia para o tratamento das doenças periodontais, sendo estes procedimentos também indicados na prevenção e manutenção após a terapia cirúrgica dessas infecções. Os efeitos clínicos de raspagem e alisamento radicular indicariam haver diminuição da profundidade de sondagem e melhora nos níveis de inserção.

RAMS; SLOTS ${ }^{58}$, em 1996, afirmaram que os procedimentos terapêuticos atuais indicam que as doenças periodontais poderiam ser controladas pela supressão de algumas espécies de microrganismos da placa subgengival que são consideradas patogênicas e pela interferência na recolonização destes sítios por essas bactérias. Observaram que o debridamento mecânico/cirúrgico na região radicular usualmente não erradica certos microrganismos como $A$. actinomycetemcomitans, $P$. gingivalis, $P$. intermedia, $B$. forsythus e $P$. micros do ecossistema subgengival devido ao seu potencial nvasivo para as células epiteliais e 
tecido conjuntivo subepitelial. Com o intuito de intensificar a ação da raspagem e do alisamento radicular no tratamento das periodontites, o emprego de agentes antimicrobianos tópicos como os bochechos bucais ou a irrigação do sulco gengival e a colocação de dispositivos que liberem lenta e gradualmente essas substâncias foram propostos.

Segundo KORNMAN ${ }^{36}$, em 1997, o emprego de agentes antimicrobianos tópicos como os bochechos bucais, a irrigação do sulco gengival e a colocação de dispositivos que liberem lenta e gradualmente essas substâncias foram propostos com o intuito de intensificar a ação da raspagem e do alisamento radicular no tratamento das periodontites.

De acordo com GREENE ${ }^{17}$, em 1997, vários fatores influenciariam a eficácia de um antibiótico nas áreas periodontais: susceptibilidade dos patógenos para a droga utilizada, ligação da droga aos tecidos, ligação ou consumo da droga pelos microorganismos considerados não alvos, que protegeriam os periodontopatógenos, capacidade de alguns microorganismos invadirem os tecidos periodontais, conferindo inacessibilidade aos antibióticos colocados subgengivalmente, o total de bactérias na bolsa periodontal poderia exceder a concentração máxima do antibiótico, sendo insuficiente para eliminar todos os microrganismos presentes, alguns antibióticos são bacteriostáticos para os patógenos, sem necessariamente erradicá-los, os microrganismos patogênicos podem residir na mucosa bucal, língua, tonsilas ou a superfície da gengiva podendo estarem inacessíveis aos antibióticos que são secretados no fluido gengival, algumas bactérias podem inativar o antibiótico por atividade enzimática, por exemplo, uma beta lactamase que destrói a atividade do 
anel beta lactâmico do antibiótico, a microbiota subgengival pode ser considerada como um biofime e apresentar maior resistência a ação dos antibióticos.

SOSKOLNE et al. ${ }^{70}$, em 1997, através de um estudo multicentro realizado na Europa, compararam duas modalidades de tratamento, em 118 pacientes portadores de periodontite de adulto, nos quais em um hemiarco da maxila foi realizado a raspagem e alisamento radicular (controle) e, no outro seguimento foi associado à colocação do PerioChip ${ }^{\circledR}$ a este procedimento (experimento). Os parâmetros clínicos foram avaliados no início, após um, três e 6 seis meses. Após três e seis meses, os autores verificaram uma redução significante na redução de profundidade de sondagem para os indivíduos do grupo teste quando comparado com os do controle, com uma média de diferença de $0,42 \mathrm{~mm}$ após seis meses. O índice gengival foi significantemente melhor para o grupo teste do que para o controle, tanto no período de três e seis meses.

PALCANIS et al. ${ }^{57}$, em 1997, realizaram um estudo aleatório em 35 pacientes com periodon tite do adulto e com bolsas periodontais de 5 a 8 mm, no qual avaliaram a ação da pastilha de clorexidina (PerioChip®) em preservar o osso alveolar quando usado como coadjuvante aos procedimentos de raspagem e alisamento radicular. Realizou-se raspagem e alisamento radicular em todos os pacientes por uma hora, sendo que o grupo controle recebeu uma pastilha placebo no período inicial e após três e seis meses e em alguns sítios não foram colocados pastilhas e o grupo teste recebeu a pastilha de clorexidina nos mesmos períodos. Foram realizadas radiografias padronizadas através de subtração radiográfica no 
início e após nove meses e observou-se que 25\% dos pacientes tratados com raspagem e alisamento radicular mostraram perda óssea em um ou mais sítios, enquanto aqueles que receberam a pastilha de clorexidina não mostraram perda óssea. Também observou-se que $60 \%$ de perda óssea observada nos pacientes que não receberam a pastilha de clorexidina foi encontrada em $39 \%$ dos pacientes fumantes.

FINKELMAN; WILLIAM S ${ }^{12}$, em 1998, verificaram que os bochechos com clorexidina foram efetivos no tratamento de gengivite, porém não para as periodontites, presumivelmente pela baixa penetração deste agente na bolsa periodontal. Devido à dificuldade de manter uma concentração suficiente deste agente por um período adequado de tempo, o emprego de uma única ou repetidas irrigações de bolsas periodontais com clorexidina, não foi considerado como um coadjuvante nas terapias periodontais.

Os agentes antimicrobianos utilizados como coadjuvantes no tratamento periodontal foram enumerados por MAGNUSSON ${ }^{46}$, em 1998, como sendo clorexidina, doxiciclina, fluoreto, metronidazol, minociclina, sanguinarina e tetraciclina. Para os sistemas de liberação local utilizados em terapia periodontal podem ser empregados a irrigação e os sistemas de liberação lenta (tubos, géis, fibras e pastilhas). A irrigação subgengival apresenta as vantagens de ser de fácil aplicação pelo profissional e apresentar alta concentração, porém tem desvantagens como difícil aplicação pelo paciente, rápida eliminação e necessidade de repetidas aplicações. Os sistemas de liberação lenta apresentam como vantagem concentração alta e prolongada, aplicações menos freqüentes, maior 
aceitação pelo paciente e como desvantagem a sua aplicação ser realizada somente pelo profissional.

KILLOY $^{31}$, em 1998, descreveu o PerioChip ${ }^{\circledR}$ como uma pastilha de clorexidina contendo $2,5 \mathrm{mg}$ de gluconato de clorexidina em uma matriz de gelatina hidrolizada biodegradável, apresentando na forma retangular, de cor laranja escuro, arredondado em um dos lados e medindo aproximadamente $4 \times 5 \times 0,35 \mathrm{~mm}$. E essa pastilha deveria ser indicado para a colocação após os procedimentos de raspagem e alisamento radicular, devendo a área estar bem isolada, a fim de evitar a absorção de saliva que dificultaria a sua inserção em bolsas com profundidade $\geq 5 \mathrm{~mm}$, permanecendo neste sítio por um período de sete a dez dias. Não havendo necessidade de uma nova visita para a sua remoção, o paciente deveria ser instruído a não usar escova ou fio dental nas áreas tratadas para evitar o deslocamento da pastilha, sendo indicado ou não bochechos com clorexidina durante o período de 2 semanas.

SOSKOLNE et al. ${ }^{71}$, em 1998, avaliaram a concentração de clorexidina no fluído gengival, urina e sangue de 19 pacientes portadores de periodontite do adulto, que apresentavam pelo menos quatro bolsas com profundidade entre 5 a $8 \mathrm{~mm}$, nas quais foi inserido o PerioChip ${ }^{\circledR}$. Amostras do fluído gengival foram obtidas imediatamente antes da colocação da pastilha, após 2,4 e 24 horas; decorridos 2, 3, 4, 5, 6, 8 e 9 dias. Não foi detectada a presença de clorexidina nas amostras de sangue ou de urina em nenhum dos períodos estudados. Verificou-se que o pico de concentração da clorexidina liberada no interior da bolsa gengival foi de $2000 \mu \mathrm{g} / \mathrm{mL}$ nas primeiras horas, diminuindo progressivamente durante o 
período de estudo, após quatro dias os níveis variaram de 1300 a $1900 \mu \mathrm{g} / \mathrm{mL}$ e permaneceu acima de $125 \mu \mathrm{g} / \mathrm{mL}$ por mais de oito dias.

Ao avaliarem a eficácia do PerioChip ${ }^{\circledR}$ como coadjuvante aos procedimentos de raspagem e alisamento radicular em reduzir profundidade de sondagem e melhorar o nível de inserção clínica em 447 pacientes com periodontite do adulto com bolsas periodontais de 5 a $8 \mathrm{~mm}$, JEFFCOAT et al. ${ }^{25}$, em 1998, observaram após nove meses que o grupo teste o qual recebeu o PerioChip ${ }^{\circledR}$ associado aos procedimentos de raspagem e alisamento radicular obtiveram significante melhora nos parâmetros clínicos avaliados quando comparado ao grupo controle que recebeu uma pastilha placebo associado aos procedimentos de raspagem e alisamento radicular ou somente raspagem e alisamento radicular, sendo que nos sítios do grupo teste que após três e/ou seis meses permaneceram com profundidade de sondagem $\geq 5 \mathrm{~mm}$ foi recolocado uma mva pastilha de clorexidina. Foi verificado que a proporção de pacientes que evidenciaram uma redução na profundidade de sondagem de $2 \mathrm{~mm}$ após os nove meses foi mais significante no grupo em que foi colocado a pastilha de clorexidina (19\%) comparado ao grupo controle (8\%).

Com o intuito de avaliar o tempo requerido e a facilidade para a inserção do PerioChip®, MACNEILL et al. ${ }^{45}$, em 1998, através de um questionário, respondido por estudantes de odontologia e técnicos em higiene dentária e, por dentistas e higienistas com experiência profissional que participaram da colocação deste dispositivo em 52 pacientes com periodontite de adulto, com profundidade de bolsa de pelo menos $5 \mathrm{~mm}$. Os 
autores concluíram que a inserção pode ser realizada em menos de um minuto por todos os grupos e que foi de fácil uso; fato que não eleva o custo deste procedimento, pois, o tempo de cadeira no consultório é um fator crítico para determinar a viabilidade econômicas dessa conduta clínica.

Segundo KILLOY; POLSON ${ }^{33}$, em 1998, dentre os sistemas de liberação de antimicrobianos podemos citar os que empregam fitas ou fibras não degradáveis de tetraciclina (Actisite®); géis de minociclina (Periocline $囚)$ e metronidazol (Elyzol®); sistema pó-líquido de doxiciclina (Atridox ${ }^{\circledR}$ ) e pastilhas de clorexidina (Periochip ${ }^{\circledR}$ ).

KILLOY; SAIKI ${ }^{34}$, em 1999, salientaram que o sistema de liberação local de antimicrobianos é um método que quando associado aos procedimentos de raspagem e de alisamento radicular tem-se melhores resultados clínicos, pois, elimina ou inibe diretamente as bactérias presentes, prolonga o tempo para que ocorra a reinfecção, permitindo ao profissional tratar de modo mais eficiente a forma recorrente dessa doença, por atuar sobre os microrganismos que não sofreram a ação mecânica dos procedimentos básicos de periodontia, aumentando a probabilidade de sucesso deste tratamento, sem a necessidade de uma terapia cirúrgica. Dentre os sistemas de liberação local para o tratamento de periodontites tem-se fibras de tetraciclina, polímero de doxiciclina e a pastilha de clorexidina.

De acordo com KILLOY ${ }^{32}$, em 1999, o sistema de liberação local de agentes antimicrobianos como o PerioChip ${ }^{\circledR}$ não substituiria os 
procedimentos de raspagem e alisamento radicular, sendo indicado como um coadjuvante à terapia local e nos sítios que após um intervalo de três meses houvesse persistência de bolsas com profundidade $\geq 5 \mathrm{~mm}$. Também ressaltou que os sistemas de liberação local de antimicrobianos não seriam apropriados para todos os tipos de periodontites e se múltiplos dentes adjacentes apresentassem sítios que não respondam aos procedimentos de raspagem e alisamento radicular associados a colocação de sistemas de liberação local com agentes antimicrobianos, seria necessário cirurgia periodontal. Além disso, se muitos sítios em todos os quadrantes não respondessem ao tratamento local deveria ser considerada a possibilidade de uma periodontite atípica e, em tais casos, exames laboratoriais deveriam ser realizados para detectar a presença destes microrganismos e sua susceptibilidade a antibióticos para posteriormente ser realizado o tratamento sistêmico com um antibiótico apropriado.

LISSOVOY et al. ${ }^{39}$, em 1999, avaliaram a ação da raspagem e alisamento radicular (grupo controle) e deste procedimento associado com a colocação do PerioChip ${ }^{\circledR}$ em 447 pacientes com periodontite de adulto (grupo teste). Os pacientes foram avaliados após três, seis e nove meses. Verificou-se que no grupo experimental a maioria dos dentes foi indicada para a terapia de manutenção e poucos necessitaram de cirurgia periodontal, ao contrário do grupo controle, indicando não haver custo adicional para o paciente quando da utilização deste dispositivo.

De acordo com $\mathrm{CIANCO}^{5}$, em 1999, algumas características deveriam ser consideradas na escolha de um antimicrobiano de liberação local na terapia periodontal como: alcançar o sítio da doença (base da 
bolsa), atingir concentração adequada, ser mantido no local por um período adequado de tempo durante o tratamento, ser efetivo contra patógenos periodontais, ser clinicamente efetivo como terapia coadjuvante, seguro para os dentes e tecidos moles, ter efeitos colaterais adversos mínimos, não causar resistência bacteriana, ser de fácil aplicação e biodegradável.

Segundo CIANCIO ${ }^{6}$, em 1999, a clorexidina apresentaria uma molécula de cadeia longa carregada positivamente que se liga à superfície carregada negativamente das membranas biológicas das bactérias, rompe a parede celular, penetra na célula, rompe o citoplasma e a célula morre. Além disso, a clorexidina seria um antimicrobiano de amplo espectro eficiente contra um grande número de patógenos periodontais, apresentaria mínima resistência bacteriana, mínimos efeitos colaterais e raras reações alérgicas. Também salientou que o PerioChip ${ }^{\circledR}$ possui muitas características de um agente coadjuvante ideal ao tratamento periodontal por ser de fácil uso, podendo ser colocado na bolsa periodontal aproximadamente em 20 segundos, não sendo necessária sua remoção por ser biodegradável em um período de sete a dez dias; promover a liberação lenta de clorexidina, entretanto, não sendo recomendado a sua inserção em sítios com abscesso periodontal para não aumentar o desconforto do paciente.

JEFFCOAT et al. ${ }^{26}$, em 2000, realizaram um estudo em 45 pacientes com periodontite do adulto com bolsas entre 5 e $8 \mathrm{~mm}$, os quais foram divididos em dois grupos: grupo controle, o qual recebeu uma pastilha placebo e raspagem e alisamento radicular (RAR) ou somente raspagem e alisamento radicular, e o grupo teste, no qual foi realizado RAR seguido 
pela colocação do PerioChip ${ }^{\circledR}$. Após nove meses mudanças favoráveis na profundidade de sondagem e ao nível de inserção clínica foram superiores nos sítios do grupo teste em relação aos sítios do grupo controle.

Ao compararem a microbiota subgengival de sítios com periodontite crônica que receberam aleatoriamente raspagem e alisamento radicular associado a colocação do PerioChip ${ }^{\circledR}$ (grupo teste) ou somente raspagem e alisamento radicular (grupo controle), em nove pacientes, com bolsas bilaterais de 6 a 7mm, DANESHMAND et al. ${ }^{8}$, em 2000, observaram que não existiram diferenças estatisticamente significantes da quantidade total de colônias entre os grupos teste e controle, em quatro semanas após o início do tratamento. Além disso, a porcentagem dos patógenos periodontais: A. actinomycetemcomitans, $P$. gingivalis, $P$. intermedia, $B$. forsythus, Fusobacterium, Eubacterium, C. rectus, P. micros, E. corrodens, bacilos entéricos, não foi significantemente diferente entre os dois grupos. Dessa forma, sugeriram que o tratamento com o PerioChip ${ }^{\circledR}$ não promoveu vantagem antimicrobiana adicional quando comparado ao tratamento com terapia mecânica.

No mesmo ano, STABHOLZ et al. ${ }^{74}$, verificaram, em um estudo multicentro, a ação do PerioChip ${ }^{\circledR}$ associado à raspagem e alisamento radicular em 72 pacientes com periodontite do adulto e com bolsas peridontais $\geq 5 \mathrm{~mm}$ por um período de dois anos. O total de 513 sítios foram examinados.Todos os pacientes receberam raspagem e alisamento radicular e foram mantidos em um programa de controle e manutenção. No início, foi implantado a pastilha de clorexidina, e se após três meses os 
sítios ainda apresentassem bolsas $\geq 5 \mathrm{~mm}$, procedeu-se a colocação de uma segunda pastilha. Os resultados mostraram que existiu uma diminuição contínua na profundidade de sondagem após dois anos, mas esta diminuição foi marcante dos nove aos doze meses, sendo menos marcante nos doze meses seguintes. Após os dois anos, $60 \%$ dos pacientes tiveram pelo menos duas bolsas mostrando redução de pelo menos $2 \mathrm{~mm}$ e somente $10 \%$ dos pacientes não apresentaram mudanças ou aumento na profundidade de sondagem.

No ano seguinte, HEASMAN et al. ${ }^{23}$, determinaram a eficácia da pastilha de clorexidina (PerioChip ${ }^{\circledR}$ ) em um estudo aleatório no qual participaram 26 pacientes com periodontite crônica com, no mínimo, uma bolsa com pelo menos $5 \mathrm{~mm}$ de profundidade de sondagem em cada hemiarco. Os sítios foram divididos em dois grupos, sendo que no grupo controle só foi realizado raspagem e alisamento radicular, enquanto no grupo teste além da raspagem e alisamento radicular, os sítios receberam a pastilha de clorexidina. Um sítio de cada hemiarco (direito e esquerdo) foi selecionado aleatoriamente para participar de um dos dois grupos. Após um, três e seis meses os pacientes foram reexaminados e observou-se que somente após seis meses houveram diferenças estatisticamente significantes entre os grupos teste e controle, ocorrendo uma maior redução na profundidade de sondagem e no índice de sangramento no grupo teste.

CRUZ et al. ${ }^{7}$, em 2001, avaliaram a eficiência da pastilha de clorexidina (PerioChip $\left.{ }^{\circledR}\right)$ quando utilizado como coadjuvante à instrumentação mecânica no tratamento de dez pacientes com doença 
periodontal crônica, nos quais foram selecionados 20 sítios bilaterais em caninos com vitalidade pulpar. Os sítios foram divididos em grupo I, composto por bolsas periodontais variando entre 5 e $7 \mathrm{~mm}$, e grupo 2 , composto por bolsas periodontais maiores que $7 \mathrm{~mm}$. Em todos os pacientes foram realizados terapia periodontal inicial e retalho mucoperiosteo para instrumentação periodontal com instrumentos manuais, ultra-sônicos e rotatórios. Nos sítios-teste, foi implantado a pastilha de clorexidina após a instrumentação e o retalho foi reposicionado e suturado. Nos sítioscontrole o retalho foi reposicionado sem implantação da pastilha. Os parâmetros clínicos foram avaliados nos períodos inicial, 7, 14, 21, 30, 60 e 90 dias após a implantação e mostraram que houve redução na inflamação gengival, mas essa resposta foi encontrada tanto nos sítios-teste como nos sítios-controle. A instrumentação isolada ou em associação com a implantação da pastilha de clorexidina proporcionou ganho de inserção, redução na profundidade de sondagem e recessão da margem gengival em todos os sítios, mas foi maior nos sítios do grupo 2, composto por bolsas periodontais maiores que $7,0 \mathrm{~mm}$. Além disso, não houve diferença estatística significativa após 90 dias de avaliação para os sítios-teste e controle. Os autores concluíram que a utilização da pastilha de clorexidina associada à instrumentação mecânica mostrou eficiência clínica para a resolução do processo inflamatório; contudo, sua utilização não representou benefício adicional no ganho de inserção clínica quando comparado com a terapia convencional. 
3 PROPOSIÇÃO 


\section{PROPOSIÇÃO}

Diante das premissas anteriormente apresentadas, propusemos:

1.avaliar e comparar longitudinalmente os sítios teste e controle em relação:

1.1. aos parâmetros clínicos da doença periodontal

1.2. à microbiota subgengival

2. correlacionar os achados clínicos com os microbiológicos

3. comparar a performance de dois meios de cultura 
4 MATERIAL E MÉTODOS 


\section{MATERIAL E MÉTODOS}

\subsection{Seleção dos pacientes}

Foram selecionados dez pacientes com periodontite crônica (cinco homens e cinco mulheres), com idade entre 28 e 50 anos, nos quais foram avaliados os parâmetros clínicos: índice de placa (SILNESS; LÖE ${ }^{60}$, em 1964) índice gengival (LÖE et $\mathrm{al}^{40}$, em 1967), profundidade de sondagem, recessão gengival e nível de inserção clínica. Foram obtidas radiografias periapicais de todos os sítios, através da técnica do cone longo. Os pacientes foram informados dos procedimentos desta pesquisa (Anexo A) e assinaram um termo de consentimento livre e esclarecido, conforme exigência do Comitê de Ética em Pesquisa da Faculdade de Odontologia de Bauru da Universidade de São Paulo (Anexo B) para sua total aprovação (Anexo C).

De acordo com a classificação da Academia Americana de Periodontia $^{3}$, em 1999, a periodontite de adulto recebeu uma nova designação (periodontite crônica), visto que este tipo de periodontite comumente encontrada em adultos, de acordo com dados epidemiológicos e experiências clínicas, pode também ser encontrada em pacientes jovens. $\mathrm{O}$ PerioChip ${ }^{\circledR}$ * (Figura 1) foi desenvolvido para ser aplicado em pacientes com periodontite de adulto, mas em virtude dessa nova classificação utilizamos o termo peridontite crônica.

\footnotetext{
* Produzido por Perio Products Ltd - Jerusalém - Israel Importado, acondicionado e distribuido por Astra Química e Farmacêutica LTDA Tamboré - Barueri - SP
} 


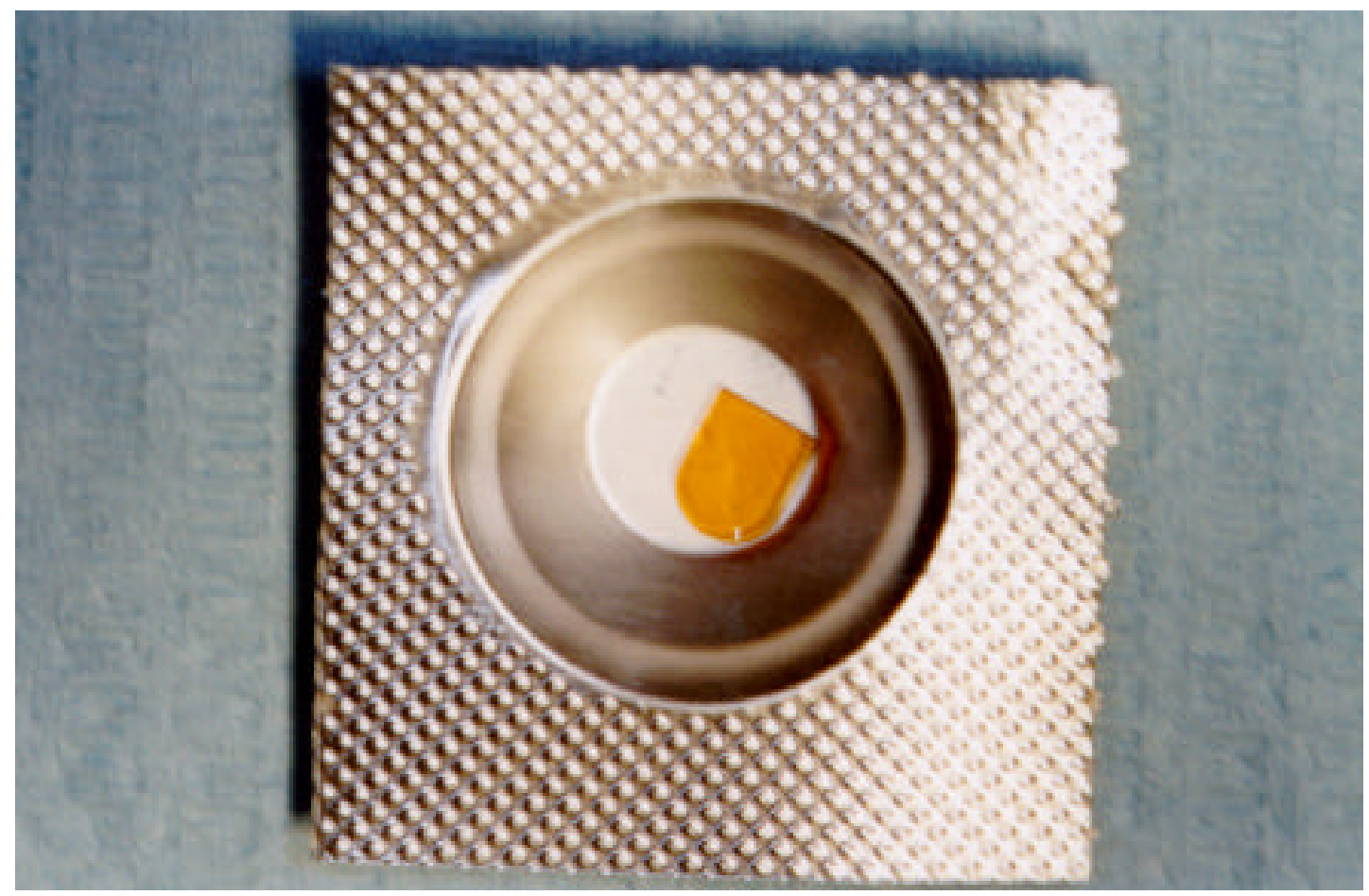

FIGURA 1 Dispositivo de liberação lenta (PerioChip $\left.{ }^{\circledR}\right)$ contendo 2,5mg de gluconato de clorexidina em uma matriz biodegradável, apresentando forma retangular, de cor laranja escuro, arredondado em um dos lados e medindo aproximadamente $4 \times 5 \times 0,35 \mathrm{~mm}$

Os critérios de seleção dos pacientes para a pesquisa foram:

Os pacientes apresentavam bolsa s periodontais com profundidade de sondagem variável de 5 a $8 \mathrm{~mm}$ em pré-molares e molares inferiores ou superiores, em hemiarcos contra-laterais, sem envolvimento da área de furca, sendo que cada um foi destinado ao sítio teste ou ao sítio controle. A avaliação da área de furca foi realizada utilizando-se a sonda de Nabers e radiografias periapicais obtidas através da técnica do cone longo. Nos sítios 
controle, foram realizados apenas raspagem e alisamento radicular e nos sítios teste além deste procedimento foi inserido a pastilha de clorexidina (PerioChip $\AA$ ). Todos os pacientes selecionados para o estudo não apresentavam histórico de alterações sistêmicas, não faziam uso de antibióticos e não foram submetidos a procedimentos de raspagem e alisamento radicular e cirurgia periodontal nos seis meses que antecederam o início da pesquisa. Da mesma forma não foram incluídos neste estudo gestantes e nem pacientes fumantes.

\subsection{Exame clínico}

O exame clínico dos pacientes foi realizado por um único profissional e as anotações foram registradas em fichas clínicas por um auxiliar (Anexo D) na Disciplina de Periodontia, Departamento de Prótese Dentária da Faculdade de Odontologia de Bauru da Universidade de São Paulo, utilizando espelho bucal e sonda periodontal milimetrada com marcações tipo Williams (HU-FRIEDY).

Os seguintes parâmetros periodontais foram registrados:

- $\quad$ Profundidade de sondagem: foi considerada como a distância da margem gengival à extensão mais apical de penetração da sonda periodontal posicionada o mais paralelo possível ao longo eixo do dente em seis locais de todos os dentes na cavidade bucal, sendo três medidas por vestibular (nos ângulos mesiovestibular e distovestibular e na região médio-vestibular) e três medidas por lingual (nos ângulos mesiolingual, distolingual e região médiolingual). Entretanto, nesta pesquisa foi registrado somente a profundidade de sondagem dos sítios teste e controle para podermos avaliar os resultados das duas modalidades de tratamento comparadas neste estudo. 
- $\quad$ Nível de inserção clínica: foi considerada como a distância entre a base da bolsa peridodontal e união amelocementária. Quando a margem gengival está localizada na coroa anatômica, o nível de inserção é determinado subtraindo-se da profundidade de sondagem a distância da margem gengival até a união amelo-cementária. Quando a margem gengival coincide com a união amelo-cementária, a perda da inserção é igual a profundidade da bolsa. Quando a margem gengival está localizada apicalmente a união amelocementária, a perda de inserção é maior do que a profundidade de sondagem e a distância da margem gengival à união amelocementária é somada à profundidade de sondagem. Nesta pesquisa foi registrado somente o nível de inserção dos sítios teste e controle para podermos avaliar os resultados das duas modalidades de tratamento comparadas neste estudo.

- $\quad$ Recessão gengival: foi considerada como sendo a distância da junção amelocementária até a margem gengival quando esta sofreu migração apical.

- $\quad$ Índice de placa: o índice utilizado foi o proposto por SILNESS; LÖE ${ }^{60}$, em 1964, no qual utilizando-se uma pinça clínica e rolos de algodão, efetuou-se o isolamento relativo da região interessada e com jatos suaves de ar, secou-se a área. Com o auxílio de cotonetes, foi aplicada a solução evidenciadora de placa, solução a $0,6 \%$ de verde malaquita em álcool a $70 \%$, dente a dente, em todas as superfícies da coroa dental. A seguir, o paciente enxaguou a boca com água por duas vezes. As faces dos dentes selecionados (mesial, distal, vestibular e lingual e/ou palatina) marcadas pelo corante foram anotadas em um diagrama apropriado contido na ficha clínica do paciente, ou sejam:

Grau 0 - ausência de placa na área gengival; 
Grau 1 - há uma película de placa que se adere à margem gengival e área adjacente ao dente, podendo ser reconhecida apenas pela passagem de uma sonda exploradora ao longo da margem gengival ou por meio da aplicação de substância evidenciadora de placa;

Grau 2 - acúmulo moderado de depósitos moles no sulco gengival, na margem gengival e/ou superfície dentária adjacente, que pode ser visto a olho nu;

Grau 3 - acúmulo abundante de material mole no sulco e/ou na margem gengival e superfície dentária adjacente.

- Índice gengival: foi determinado seguindo os critérios de $\mathrm{LÖE}^{40}$, em 1967:

Grau 0 - gengiva normal;

Grau 1 - inflamação leve, com ligeira modificação na cor, pequeno edema e nenhum sangramento à sondagem;

Grau 2 - inflamação moderada, com gengiva edemaciada, brilhante e avermelhada ou vermelho azulada e sangramento à sondagem;

Grau 3 - inflamação severa, com gengiva bastante vermelha ou vermelho azulada, edemaciada. Ulceração e tendência ao sangramento espontâneo.

A severidade da inflamação gengival é definida segundo faixas que utilizam esses escores como referência: inflamação de grau baixo (escores de $0,1-1,0)$, moderado $(1,1-2,0)$ e alto $(2,1-3,0)$.

O exame clínico foi realizado no início e 70 dias após a realização do tratamento pertinente a cada grupo. 


\subsection{Obtenção da amostra da placa subgengival}

Para a obtenção da placa dental subgengival dos sítios selecionados, isolaram-se os locais com gaze estéril, removeu-se a placa supragengival com uma cureta de Gracey 11-12 ou 13-14 (HU-FRIEDY) e em seguida, uma cureta de Gracey Mini-five 3-4 (HU-FRIEDY) estéril foi introduzida no fundo da bolsa. O biofilme foi colhido e transferido para frascos tipo penicilina $(13 \times 100 \mathrm{~mm})$ contendo de 7 a 10 pérolas de vidro e 2,5ml de tampão fosfato de sódio (PBS), previamente esterilizados. As amostras foram identificadas em cada frasco (número do paciente e do dente). A colheita do material foi realizada no período da manhã, sendo que os procedimentos laboratoriais foram realizados no laboratório da Disciplina de Microbiologia, Departamento de Ciências Biológicas da Faculdade de Odontologia de Bauru da Universidade de São Paulo, num intervalo não superior a duas horas após a sua obtenção. As amostras de placa foram obtidas e analisadas no início e após dez, 40 e 70 dias da realização da raspagem e alisamento radicular e colocação da pastilha de clorexidina (sítios-teste) ou somente raspagem e alisamento radicular (sítios-controle).

\subsection{Processamento microbiológico}

\subsubsection{Meios de cultura, soluções e reagentes}

\subsubsection{Tampão fosfato de sódio (PBS)}

O meio utilizado para transporte e diluições da amostra da placa bacteriana, foi o tampão fosfato de sódio (PBS) descrito por SORENSEN ${ }^{72}$, em 1912, que apresenta a seguinte composição: 
- $\quad \mathrm{KH}_{2} \mathrm{PO}_{4}$

$0,6 \mathrm{ml}$

- $\quad \mathrm{K}_{2} \mathrm{HPO}$

$.0,3 \mathrm{ml}$

Água destilada.

$150 \mathrm{ml}$

Foram empregados dois meios de cultura para a contagem das unidades formadoras de colônias (UFC)/mL de placa: Cells blood reinforced clostridial agar (CBRCA) e agar levedura cisteína-sangue (BYC).

\subsubsection{CBRCA}

Foi proposto por Van PALENSTEIN HELDERMAN; WINKLER $^{77}$, em 1975, para diferenciar cinco grupos de anaeróbios Gramnegativos: Vibrio (Campylobactyer) sputorum, Fusobacterium nucleatum, Bacteroides ochraceus, Selenomonas sputigena e Veillonellas e apresenta a seguinte composição: Reinforced clostridial Agar (3,8\%), azul da China (ceaneto ferroso) $0,03 \%$, nitrato de potássio $\left(\mathrm{KNO}_{3}\right) 0,1 \%$, bicarbonato de sódio $\left(\mathrm{NaHCO}_{3}\right) 0,1 \%$, menodiane $(0,5 \mu \mathrm{g} / \mathrm{ml})$, hemina $(0,1 \mu \mathrm{g} / \mathrm{ml})$, agar $(8 \%)$ e sangue desfibrinado de carneiro $(7,5 \%)$.

\subsubsection{3 Ágar Levedura-Cisteína-Sangue (YCB - yeast-cysteine-blood- agar) - BYC}

Este meio foi empregado para a detecção e contagem de unidades formadoras de colônias (UFC) dos principais periodontopatógenos: Porphyromonas gingivalis, Prevotella intermedia e Bacteroides forsythus. 
Proposto por GERSDORF et al. ${ }^{14}$, em 1993, apresenta a seguinte composição: peptona (1\%); cloreto de sódio $(0,5 \%)$; extrato de carne $(0,2 \%)$; extrato de levedura $(0,5 \%) ;$ L-cisteína-cloreto monohidratado $(0,03 \%)$; glicose $(0,2 \%)$; ágar $(2 \%)$; sangue desfibrinado de carneiro $(10 \%)$; hemina $(0,0001 \%)$; menadione $(0,0001 \%)$.

Para o preparo dos dois meios os componentes foram pesados e adicionados à água destilada. Após a homogeneização dos componentes processou-se a esterilização em autoclave a $121{ }^{\circ} \mathrm{C}$ por 15 minutos, quando o meio foi resfriado à aproximadamente $50-55^{\circ} \mathrm{C}$, para a adição do sangue desfibrinado de carneiro, distribuindo-se alíquotas de $5 \mathrm{ml}$ por cada placa de petri $(15 \times 100 \mathrm{~mm})$. Essas placas foram submetidas ao teste de esterilidade, sendo em seguida empregadas no exame bacteriológico.

\subsubsection{Exame bacteriológico}

\subsubsection{Diluição, semeadura e incubação}

Os tubos contendo amostras de placa subgengival dos sítios-teste e controle foram submetidos à agitação por um minuto em velocidade máxima (Mixtron)* (Figura 2) e à diluição decimais seriadas $\left(10^{-1}\right.$ a $\left.10^{-5}\right)$ em tubos de ensaio contendo 9ml de PBS. (Figura 3).

* Leucotron equipamentos LTDA, Série: 805/20, Santa Rita dos Pinhais 


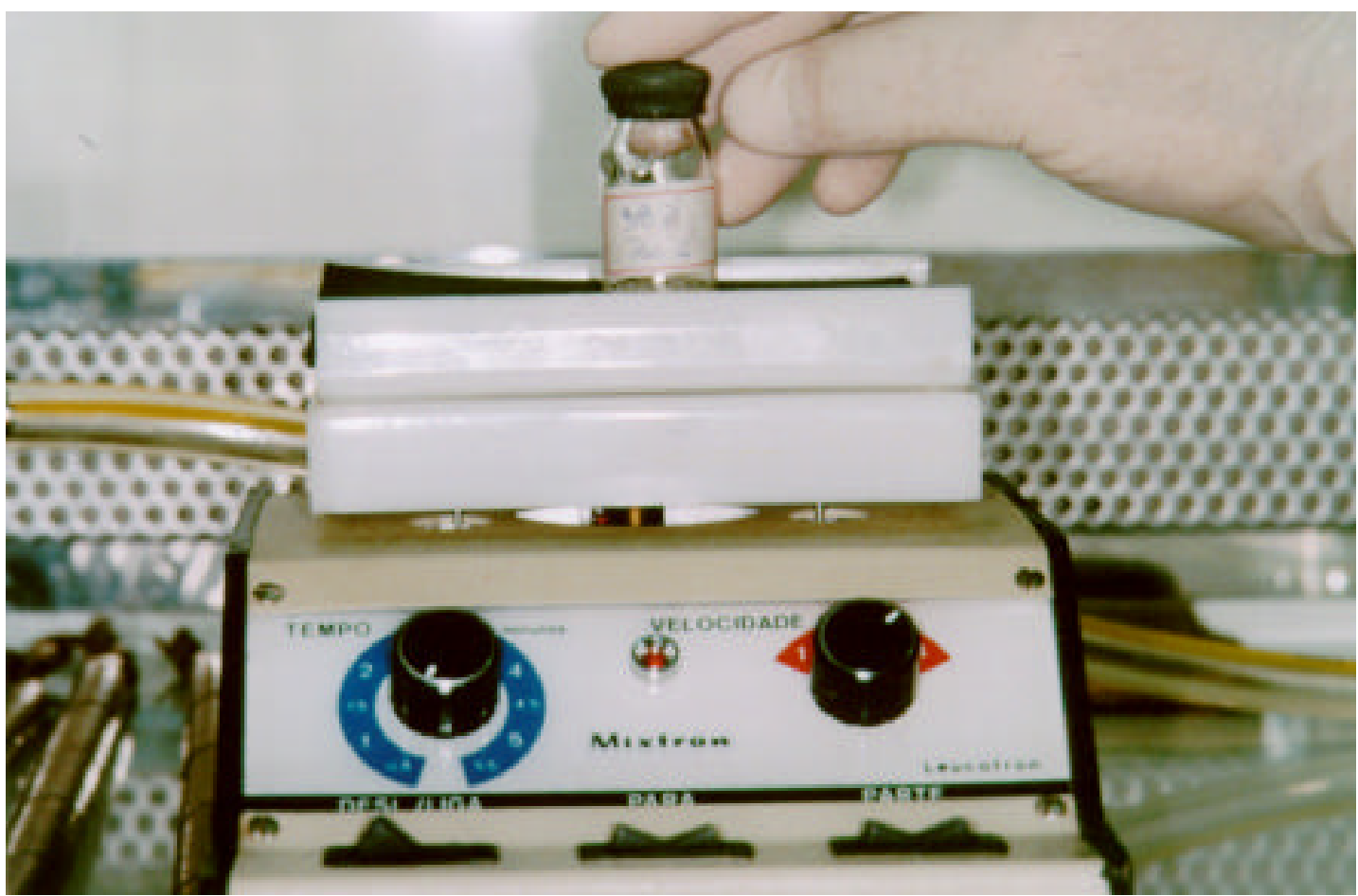

FIGURA 2 Os tubos contendo as amostras de placa bacteriana foram agitados por um minuto em velocidade máxima utilizando o Mixtron para promover sua dispersão 


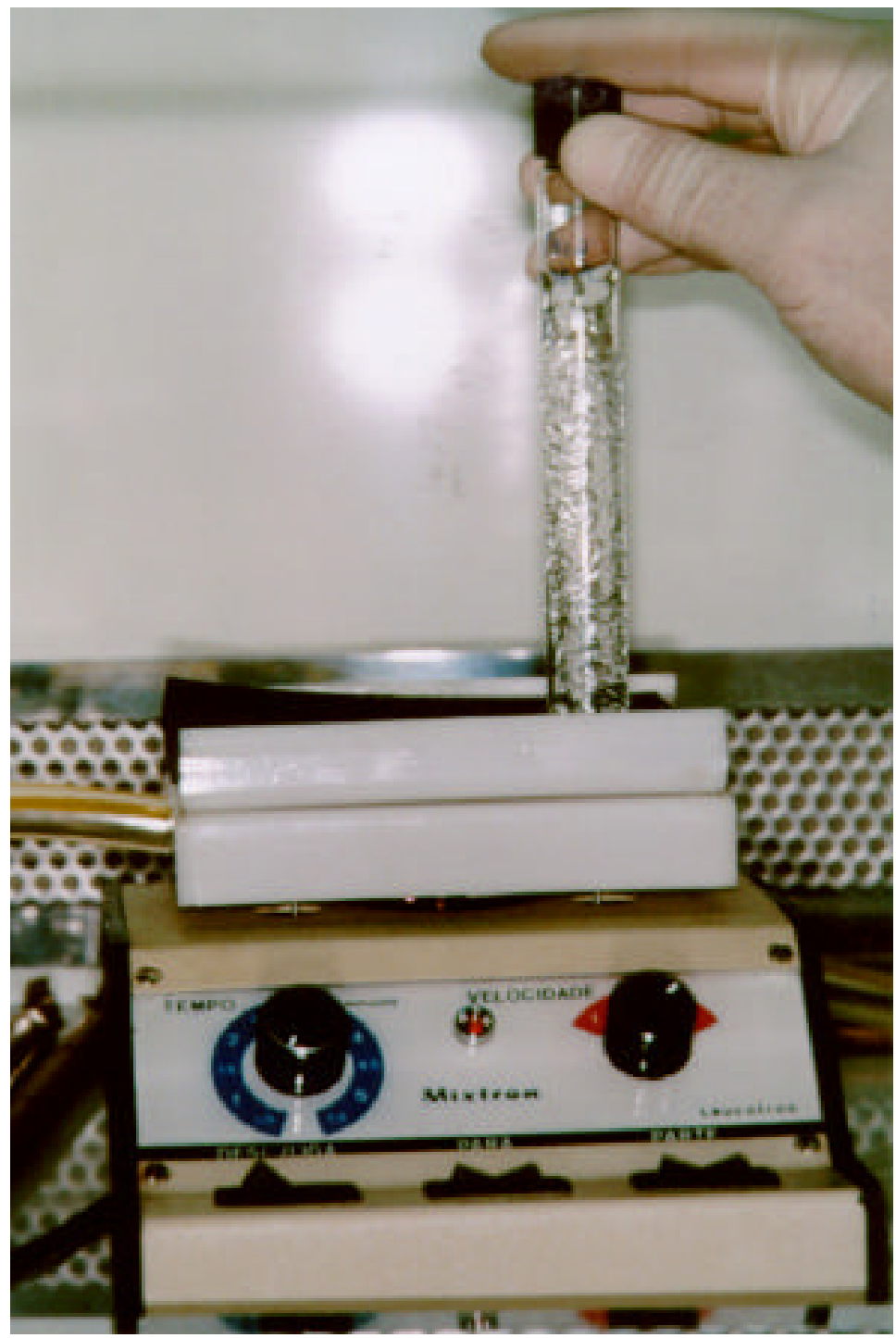

FIGURA 3 As amostras de placa bacteriana foram submetidas a diluições decimais $\left(10^{-1}\right.$ a $\left.10^{-5}\right)$ e agitadas por um minuto no Mixtron para promover sua dispersão 
Para a transferência das soluções de um tubo para outro, utilizaram-se pipetas graduadas estéreis* (Figura 4). Alíquotas de $50 \mu 1$ de placa pura e de cada diluição foram semeadas na superfície das placas contendo o meio BYC e CBRCA, através de uma pipeta graduada automática**, começando sempre da solução mais diluída para menos diluída (Figura 5).

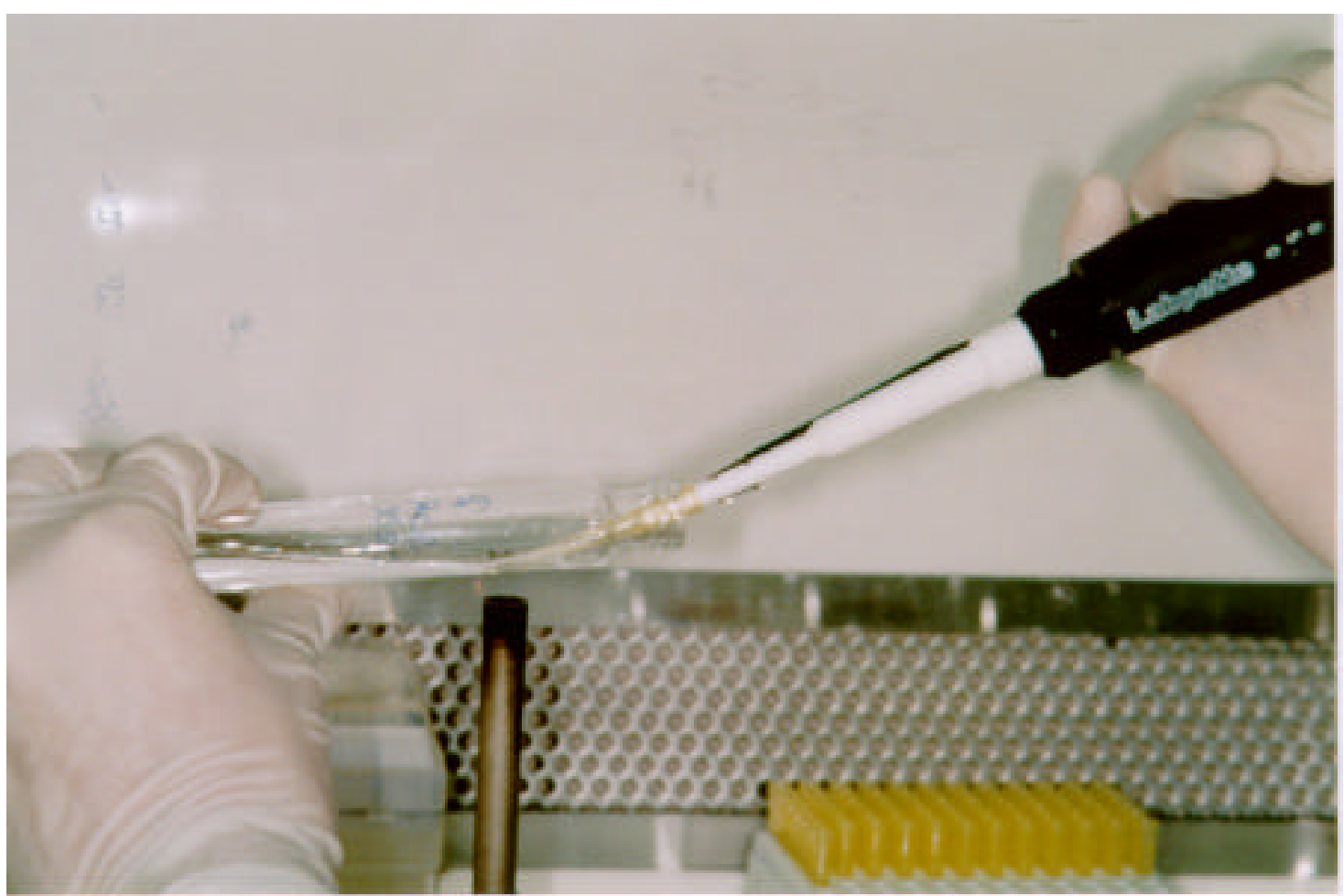

FIGURA 4 Transferência das diluições foram realizados através de pipetas graduadas estéreis

* Pipetman, Gilson, P1000 (1000 $\mu \mathrm{L})$, França

** Labpette, Labnet, $(100 \mu \mathrm{L}), \mathrm{HTL}$ 


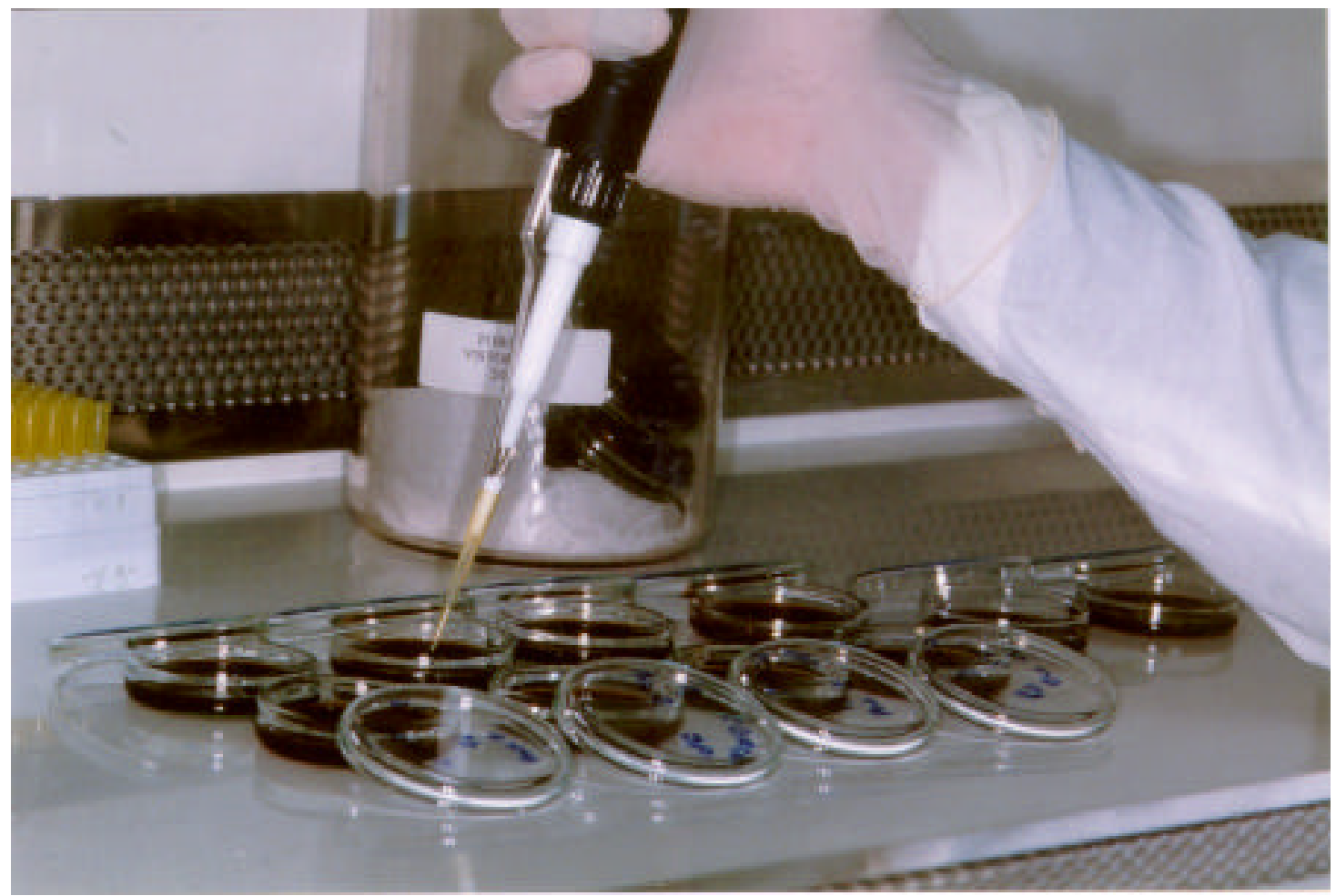

FIGURA 5 Amostras de $50 \mu \mathrm{l}$ de cada diluição foram semeadas na superfície das placas contendo o meio BYC e CBRCA, através de uma pipeta graduada automática (Labpette-Labnet)

Em seguida espalhou-se as diversas diluições sobre os meio de cultura contidos nas placas com um bastão de vidro em forma de L estéril (Figura 6). 


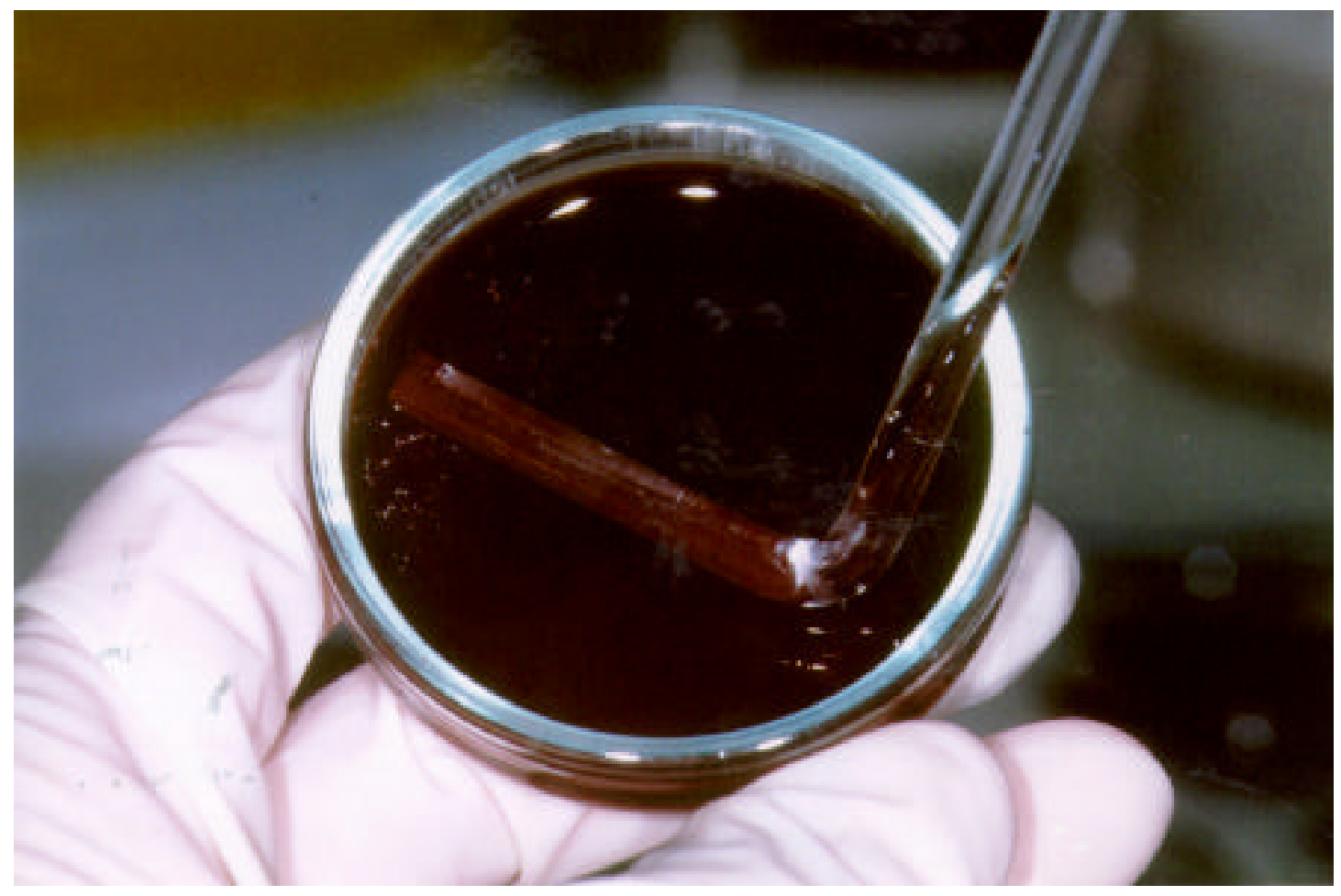

FIGURA 6 As alíquotas de placa pura e das diluições foram espalhadas sobre os meios de culturas contidos nas placas através de um bastão de vidro em L. Um mesmo bastão foi utilizado para espalhar todas as soluções, porém sempre da mais diluída para a menos diluída

As amostras de cada sítio foram semeadas em cada um dos meios BYC e CBRCA, sendo empregada uma placa para as diluição $10^{0}$ e $10^{-1} \mathrm{e}$ para as diluições $10^{-2}, 10^{-3}, 10^{-4}$ e $10^{-5}$ foram feitas duplicatas em cada meio (Figura 7). 


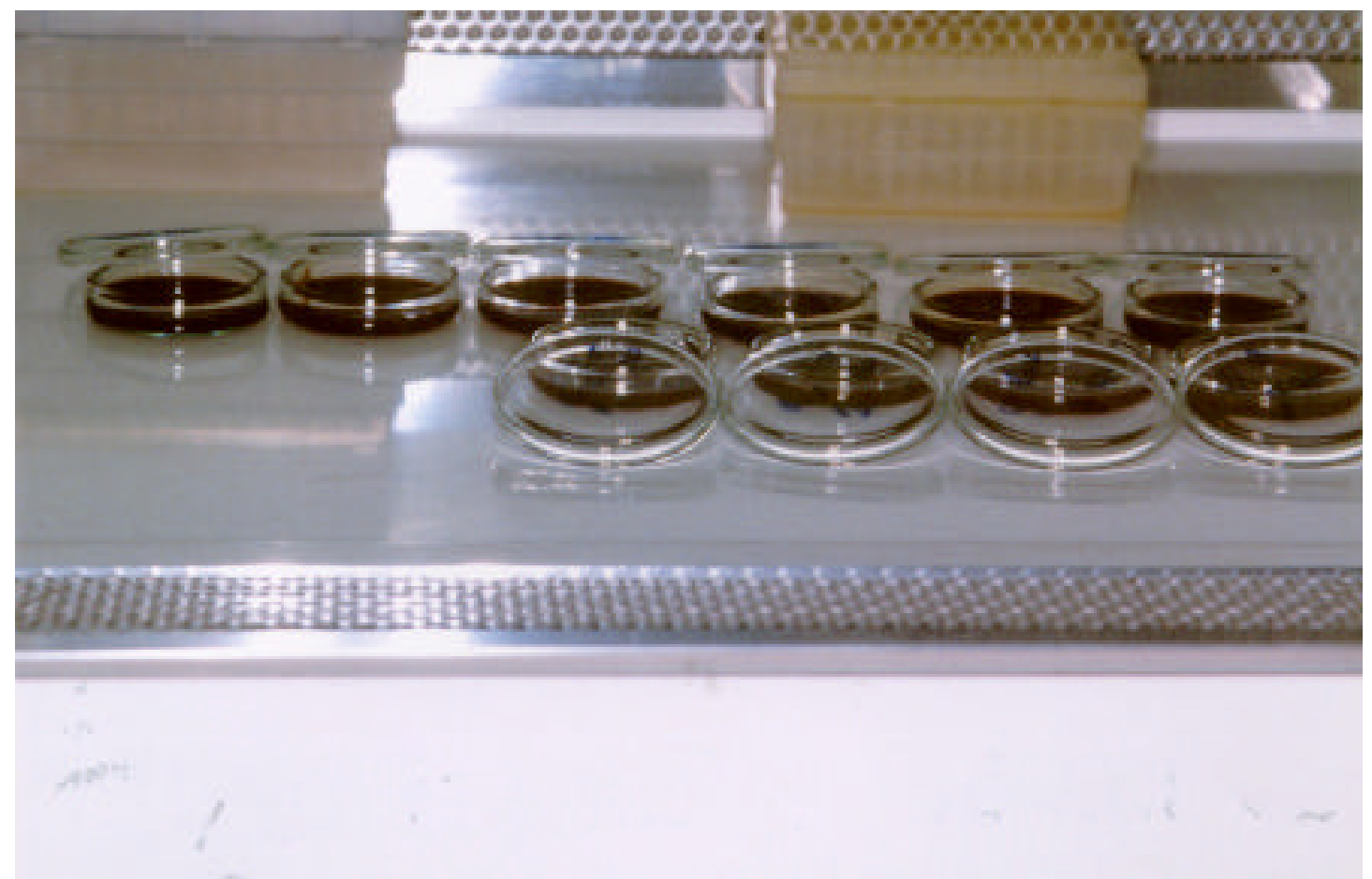

FIGURA 7 As amostras de cada sítio foram semeadas, sendo empregada uma placa de cada meio para as diluição $10^{0}$ e $10^{-1}$ e para as diluições $10^{-2}, 10^{-3}, 10^{-4}$ e $10^{-5}$ foram feitas duplicadas em cada meio.

As placas foram acondicionadas em jarras, sendo as condições de anaerobiose obtidas com o emprego do sistema Gas-Pak* (Figura 8).

* GasPak Plus, BBL ${ }^{\mathrm{TM}}$, Becton Dickinson Microbiology and Company Sparks, MD 21152, USA 


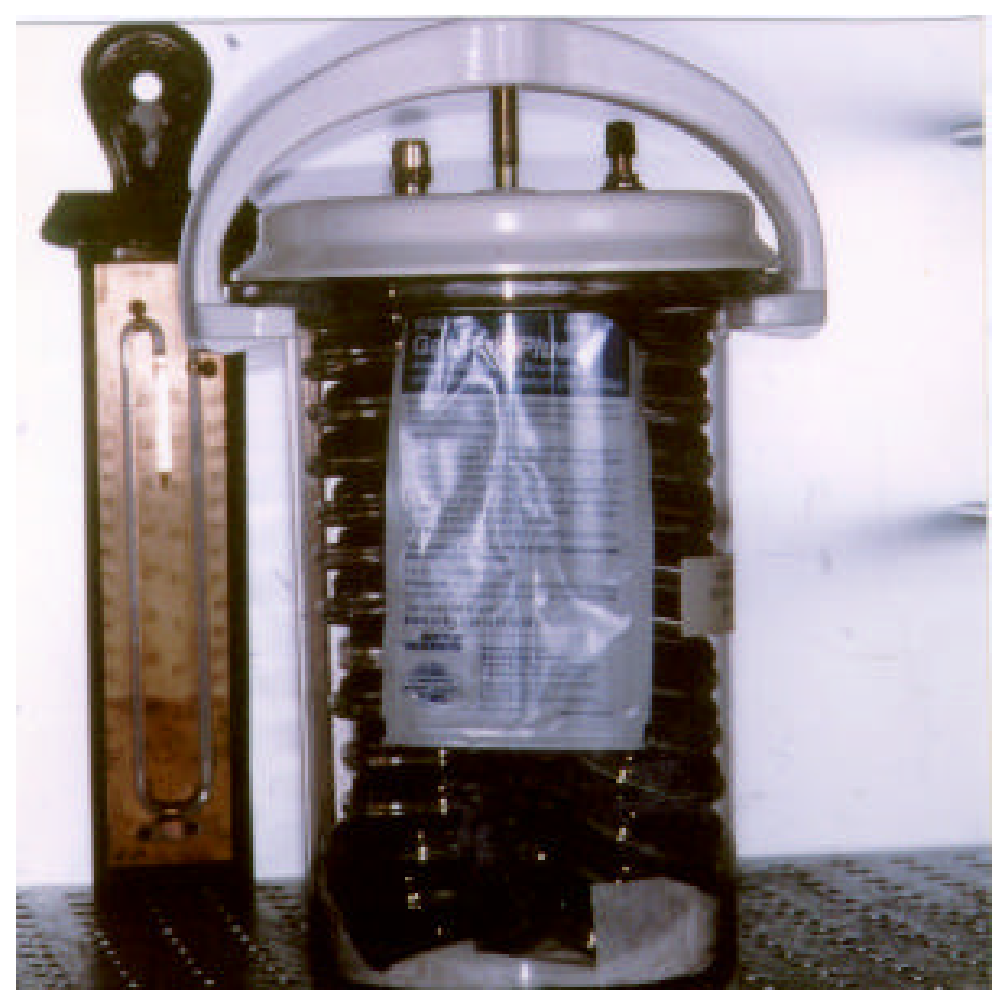

FIGURA 8 Utilizou-se o Gás-Pak para obter-se as condições de anaerobiose.

A incubação foi realizada a $37^{\circ} \mathrm{C}$, por um período de 7 a 10 dias, quando procedemos à contagem de $\mathrm{UFC} / \mathrm{mL}$ de placa (Figuras 9 a 20)*

\subsubsection{Contagem das unidades formadoras de colônias (UFC/mL de placa)}

As unidades formadoras de colônias foram contadas em cada placa utilizando um contador automático de células (Quimis)** e os resultados obtidos foram transformados em logaritmo através da seguinte fórmula:

* As fotografias 9 a $20(10 \times 15 \mathrm{~cm})$ foram tiradas com as seguintes especificações: máquina Nikon N 70, lente Macro 105mm (Nikon), abertura 11 , velocidade de sincronismo de flash $1 / 60$ segundo e altura da estativa de $13 \mathrm{~cm}$.

** Quimis Equipamentos LMTA, Série: 805/20, Santa Rita do SapucaímG, 
$X=$ Número de colônias em cada placa $\mathbf{x}$ total de diluições $\mathbf{x}$ volume

semeado. Como a quantidade semeada foi de $0,05 \mathrm{ml}(50 \mu \mathrm{l})$, tivemos que multiplicar por 20, pois queremos saber em $1 \mathrm{ml}$.

Para as diluições que foram duplicadas somaram-se os valores e obtivemos sua média. Obtidos os valores das diluição somou-se e tirou-se a média geral. Em seguida esse valor foi transformado em logarítimo $\left(\log _{10}\right)$.

As placas que apresentaram contagem superiores a 300 unidades formadoras de colônias foram excluídas.

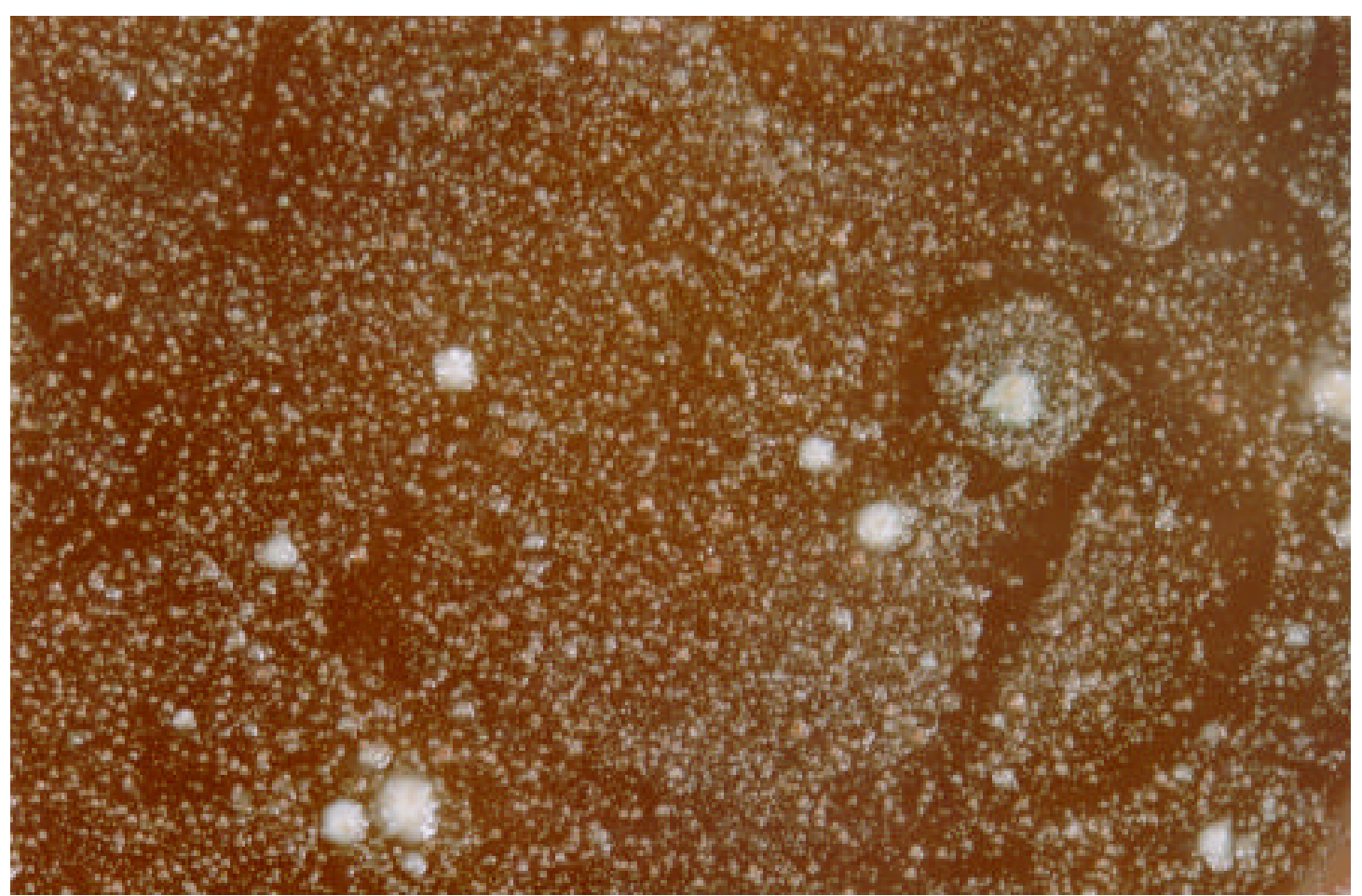

FIGURA 9 A contagem das unidades formadoras de colônias obtidas a partir da diluição $10^{0}$ no meio BYC foi realizada após incubação de 7 a 10 dias a temperatura de $37^{\circ} \mathrm{C}$ 


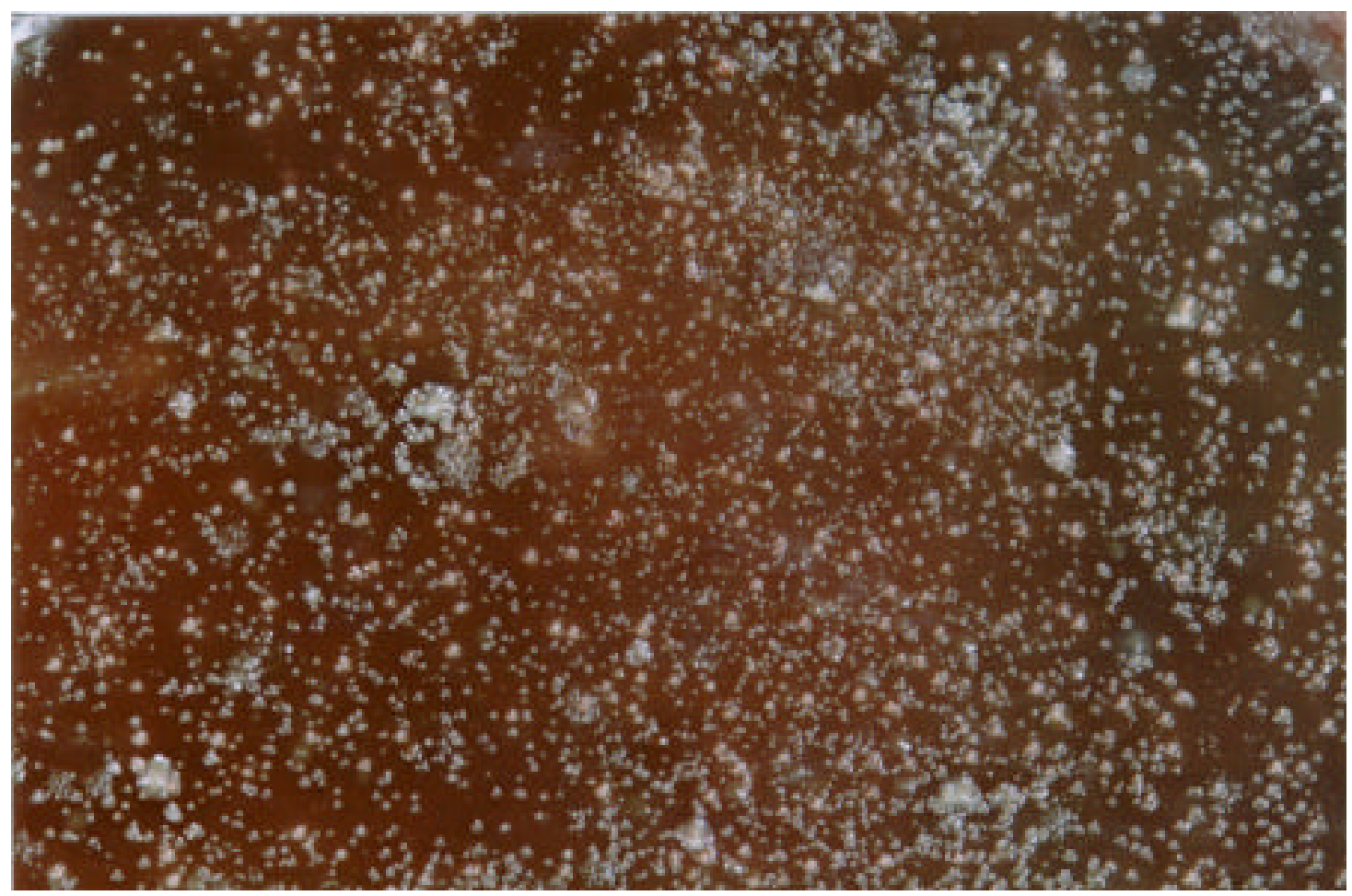

FIGURA 10 A contagem das unidades formadoras de colônias obtidas a partir da diluição $10^{-1}$ no meio BYC 


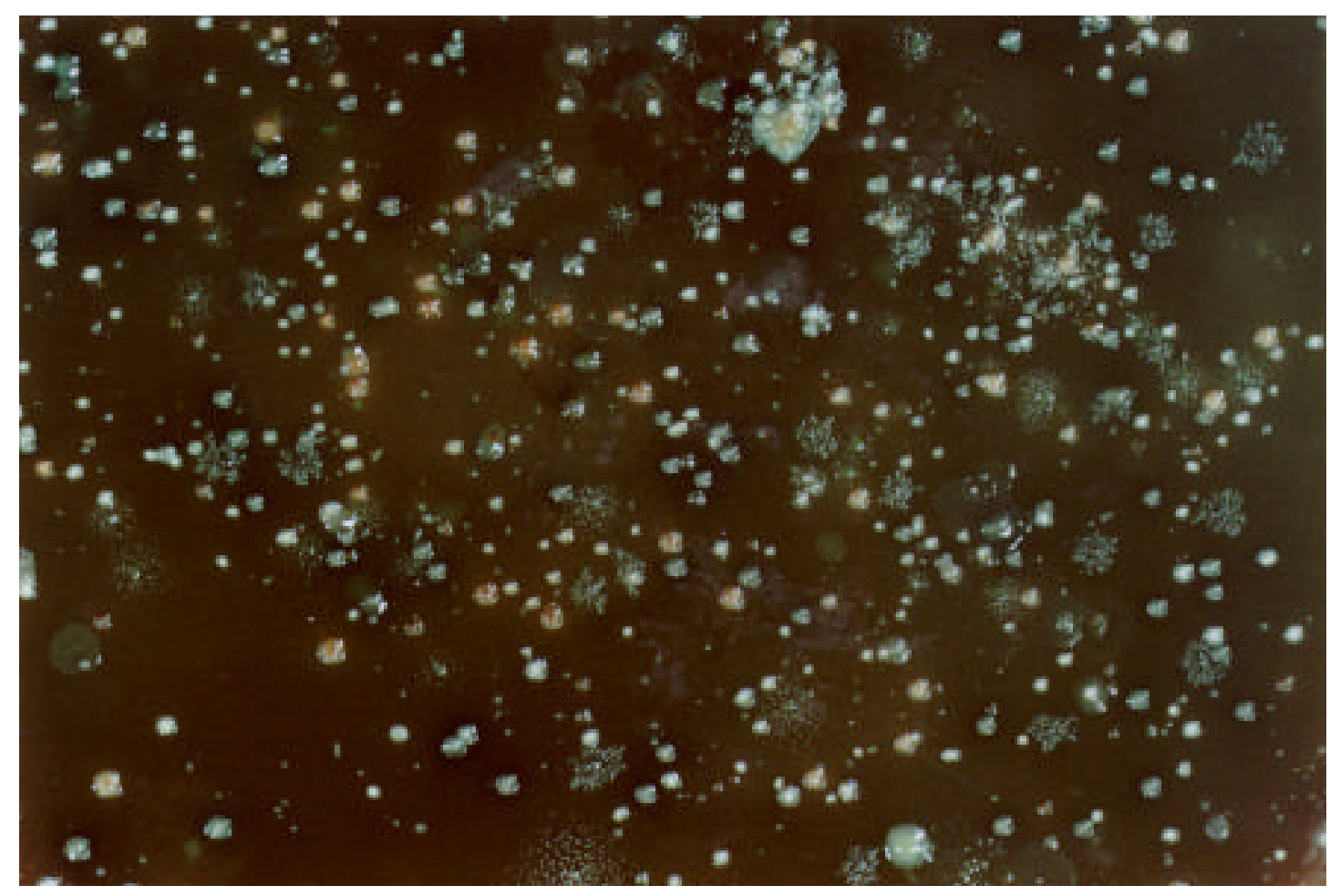

FIGURA 11 A contagem das unidades formadoras de colônias obtidas a partir da diluição $10^{-2}$ no meio BYC 


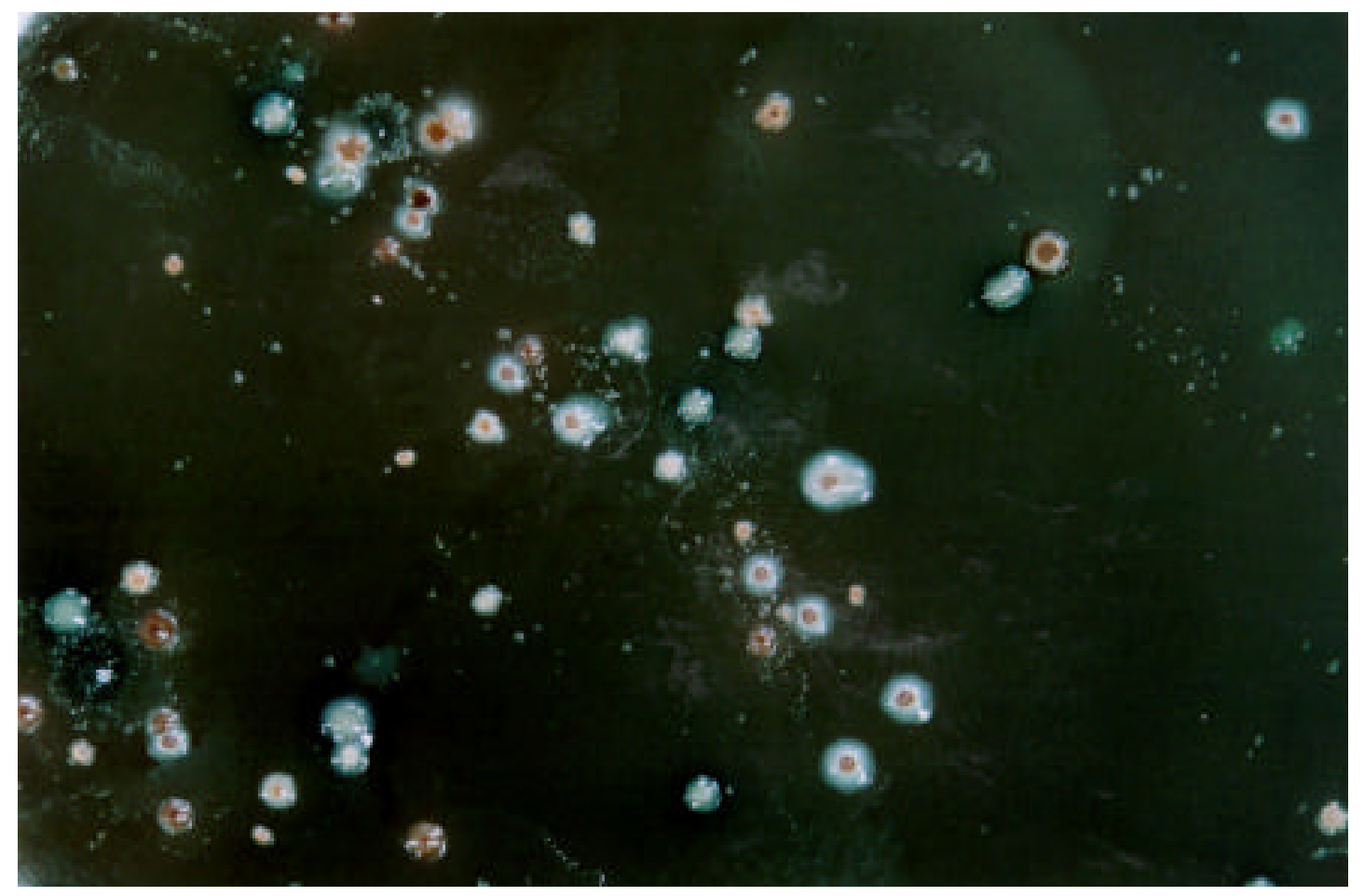

FIGURA 12 A contagem das unidades formadoras de colônias obtidas a partir da diluição $10^{-3}$ no meio BYC 


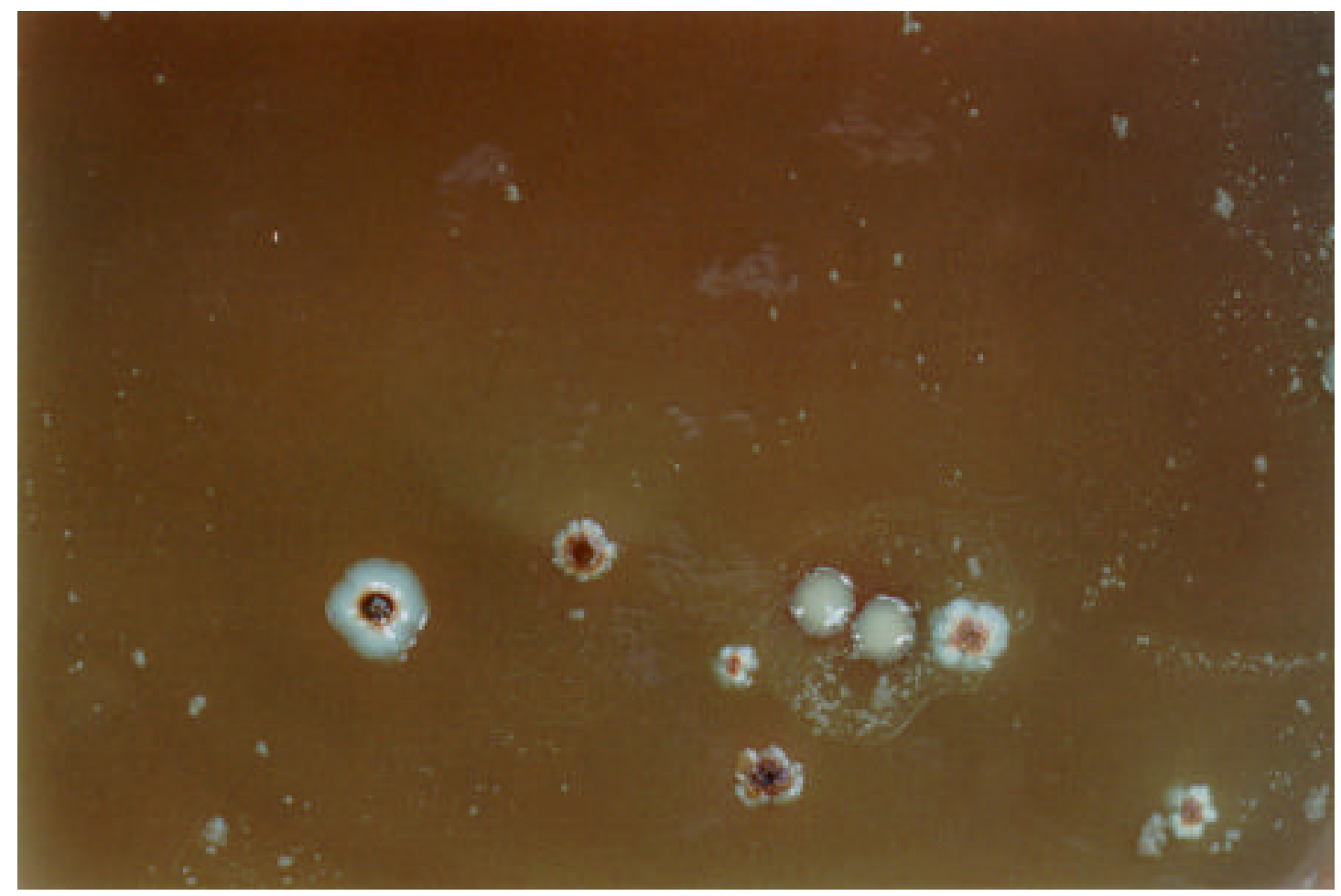

FIGURA 13 A contagem das unidades formadoras de colônias obtidas a partir da diluição $10^{-4}$ no meio BYC 
Material e Métodos 64

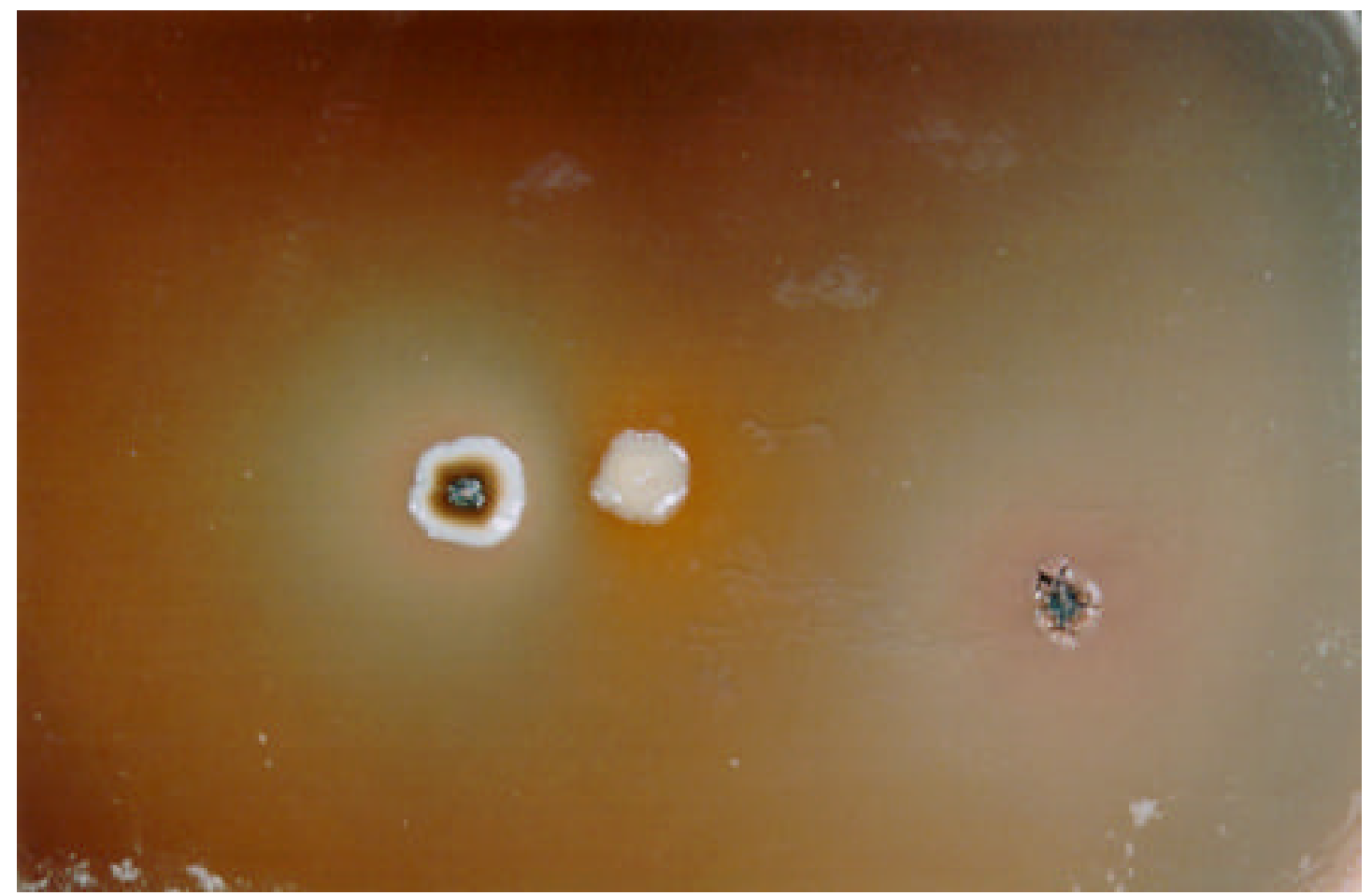

FIGURA 14 A contagem das unidades formadoras de colônias obtidas a partir da diluição $10^{-5}$ no meio BYC 


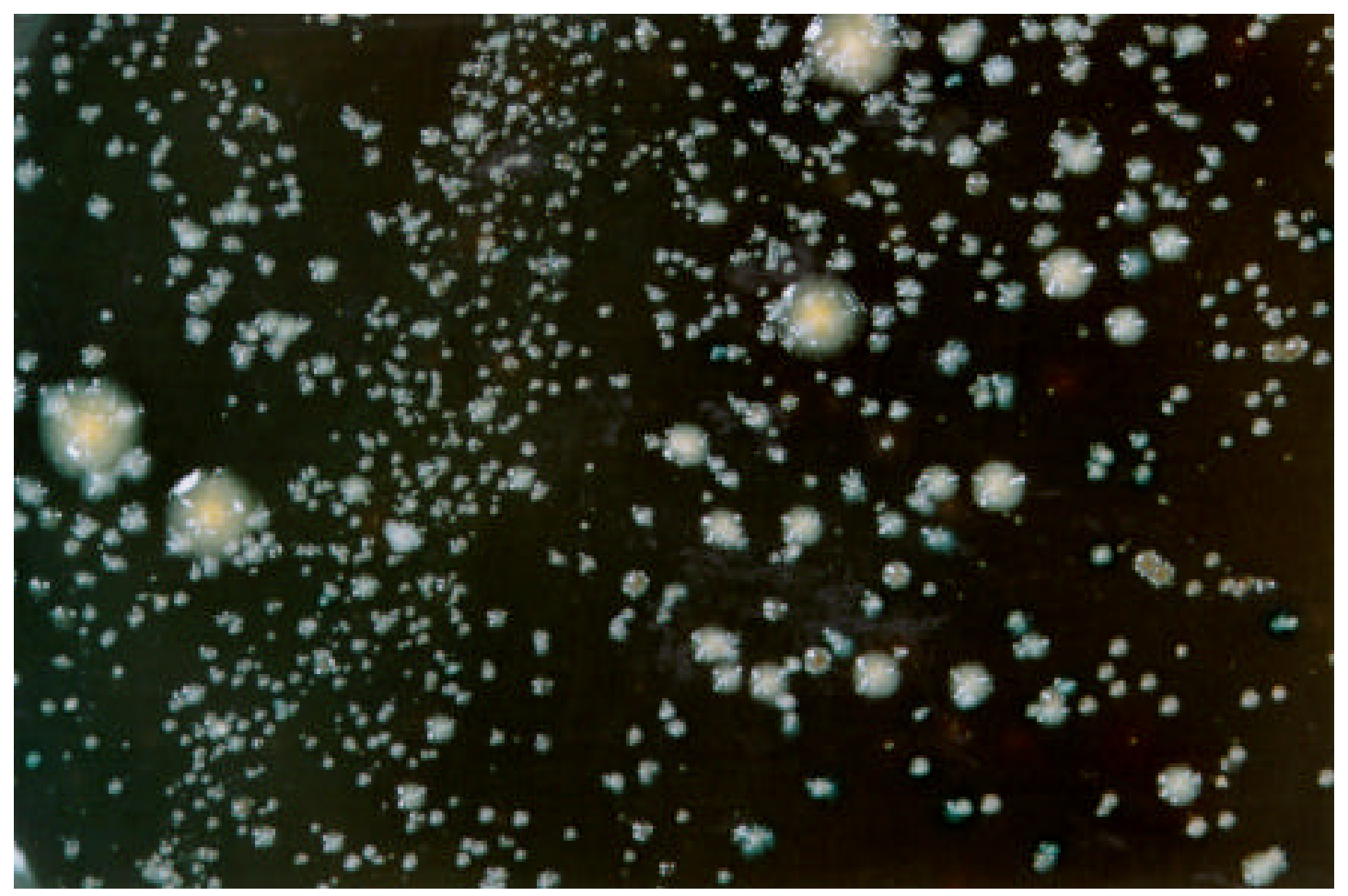

FIGURA 15 A contagem das unidades formadoras de colônias obtidas a partir da diluição $10^{\circ}$ no meio CBRCA 


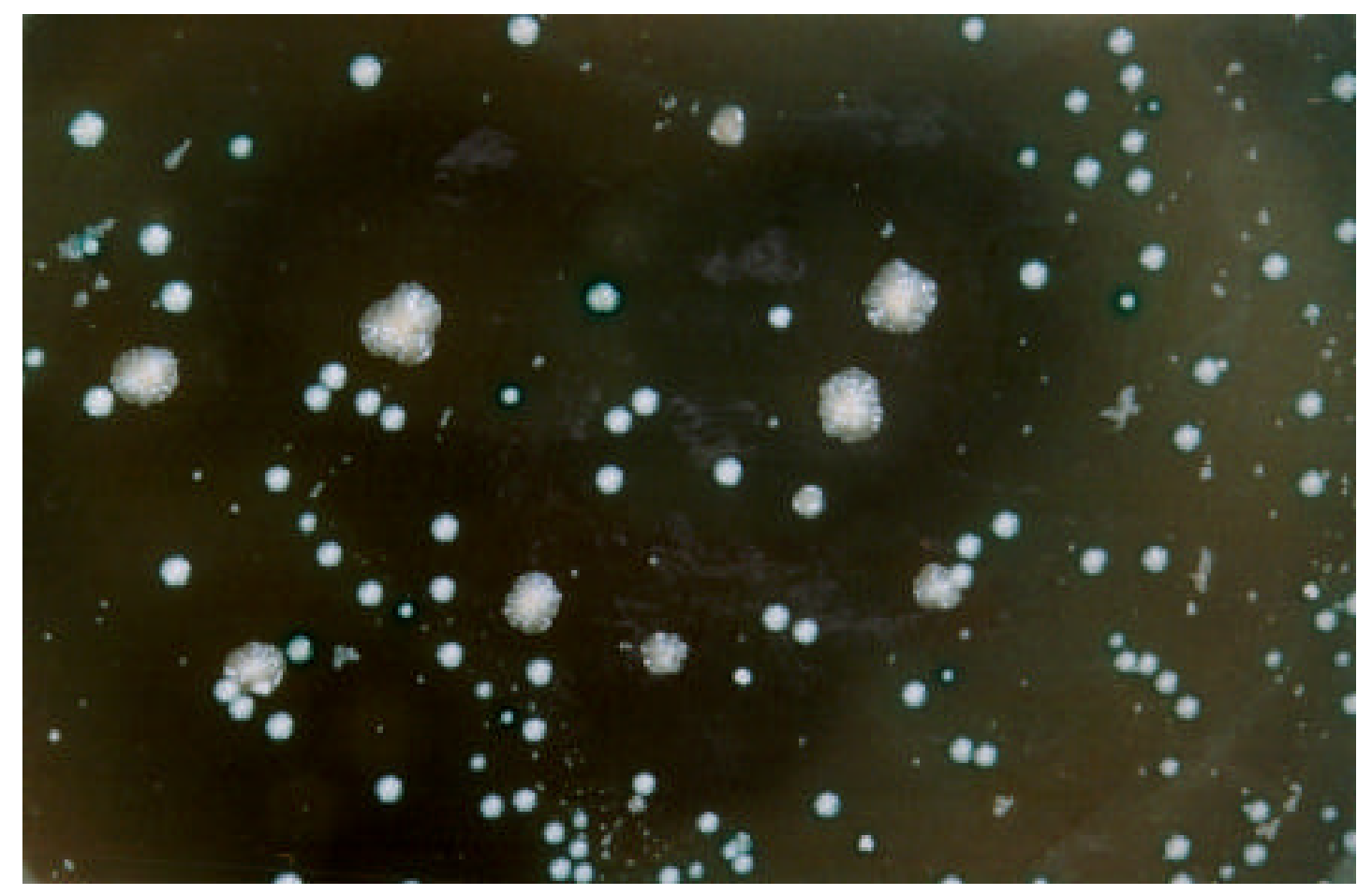

FIGURA 16 A contagem das unidades formadoras de colônias obtidas a partir da diluição $10^{-1}$ no meio CBRCA 


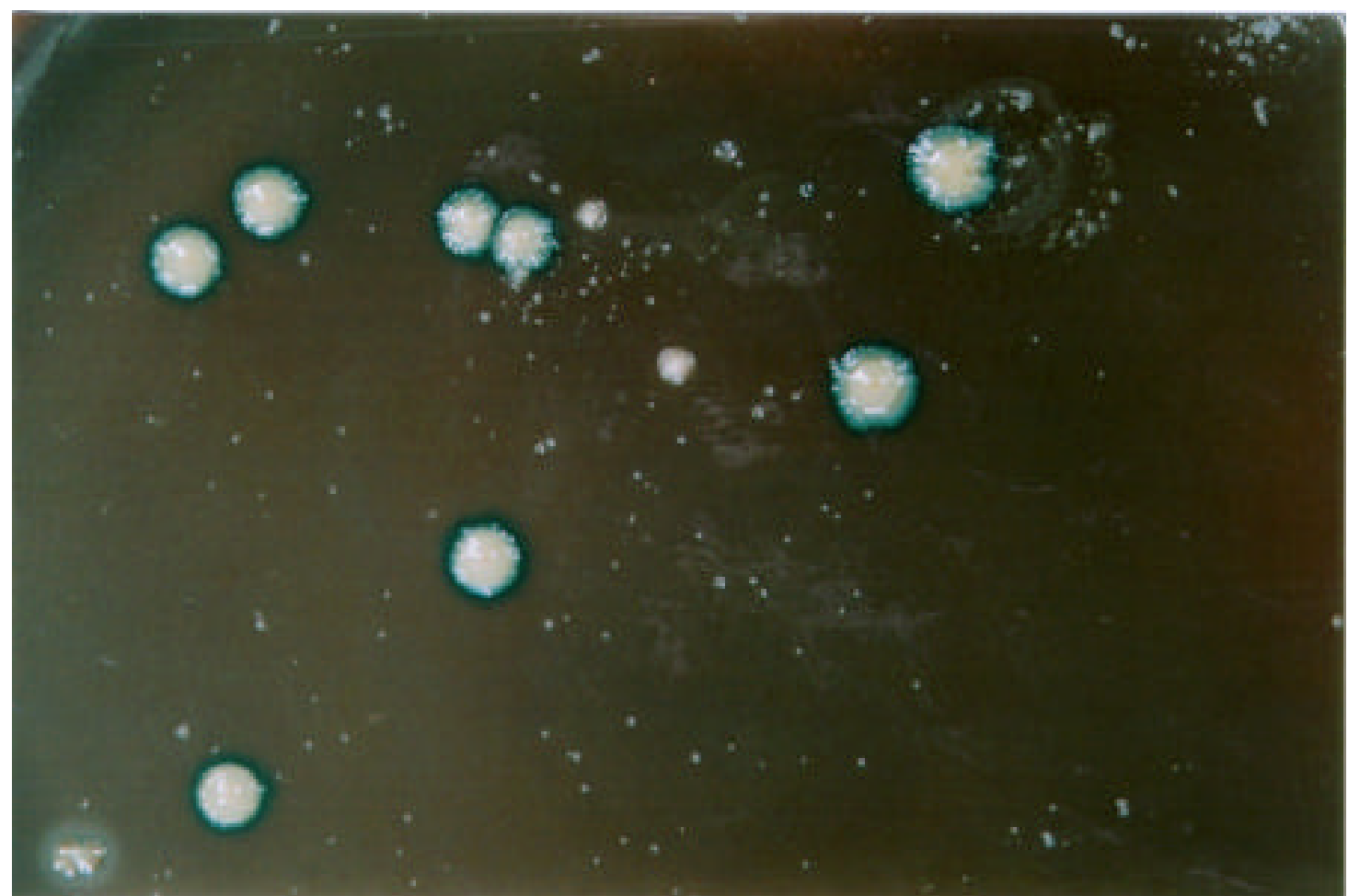

FIGURA 17 A contagem das unidades formadoras de colônias obtidas a partir da diluição $10^{-2}$ no meio CBRCA 
Material e Métodos 68

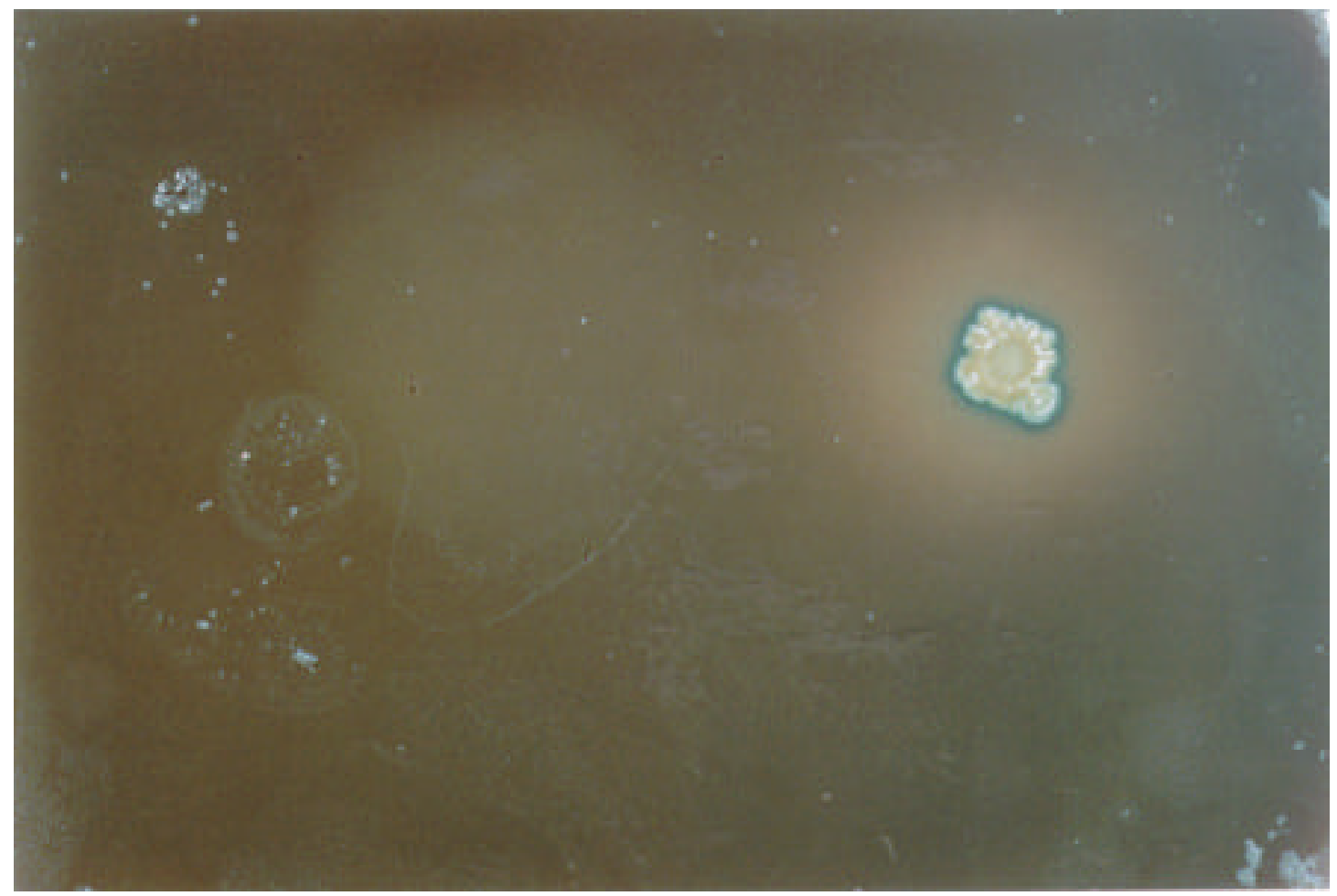

FIGURA 18 A contagem das unidades formadoras de colônias obtidas a partir da diluição $10^{-3}$ no meio CBRCA 


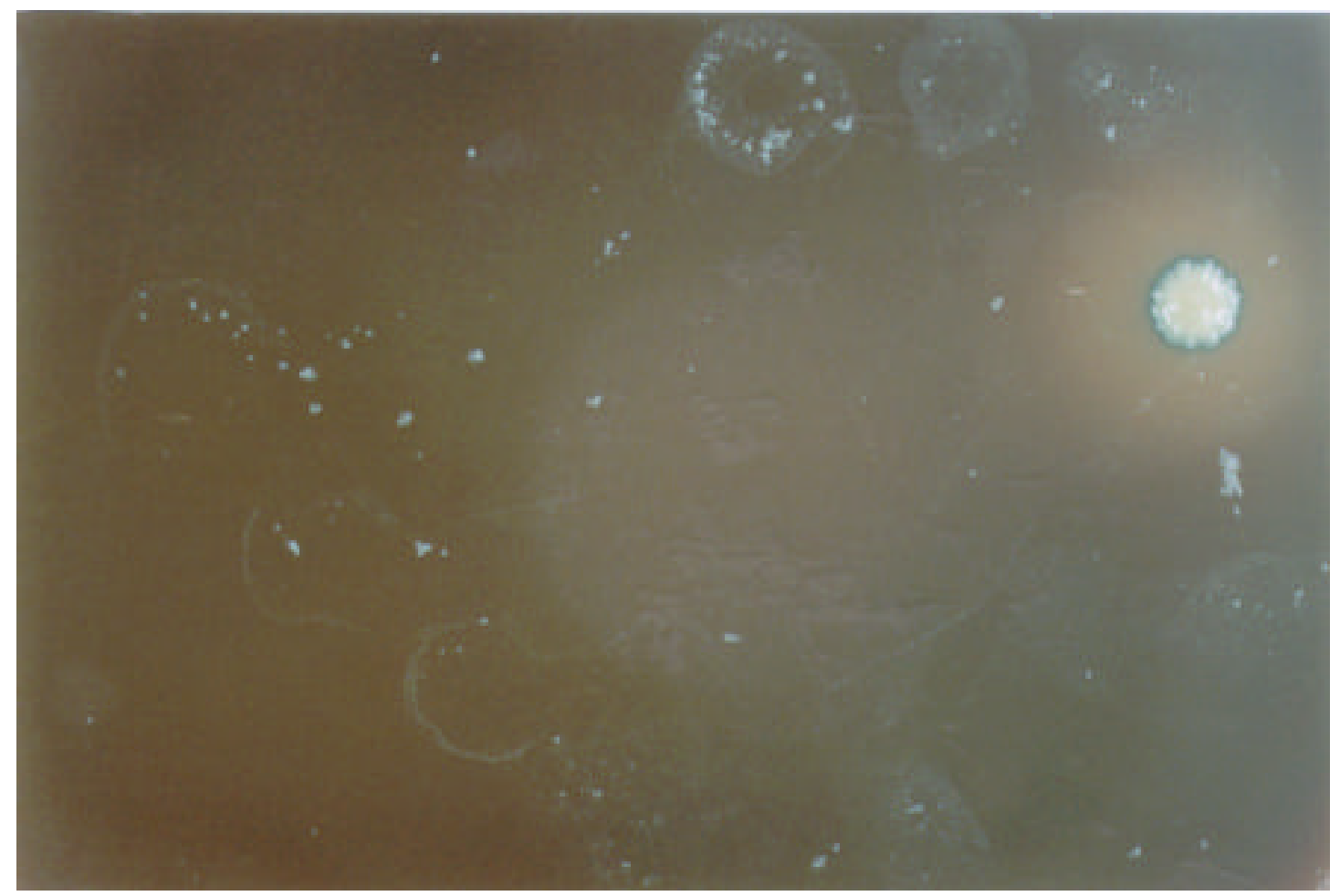

FIGURA 19 A contagem das unidades formadoras de colônias obtidas a partir da diluição $10^{-4}$ no meio CBRCA 


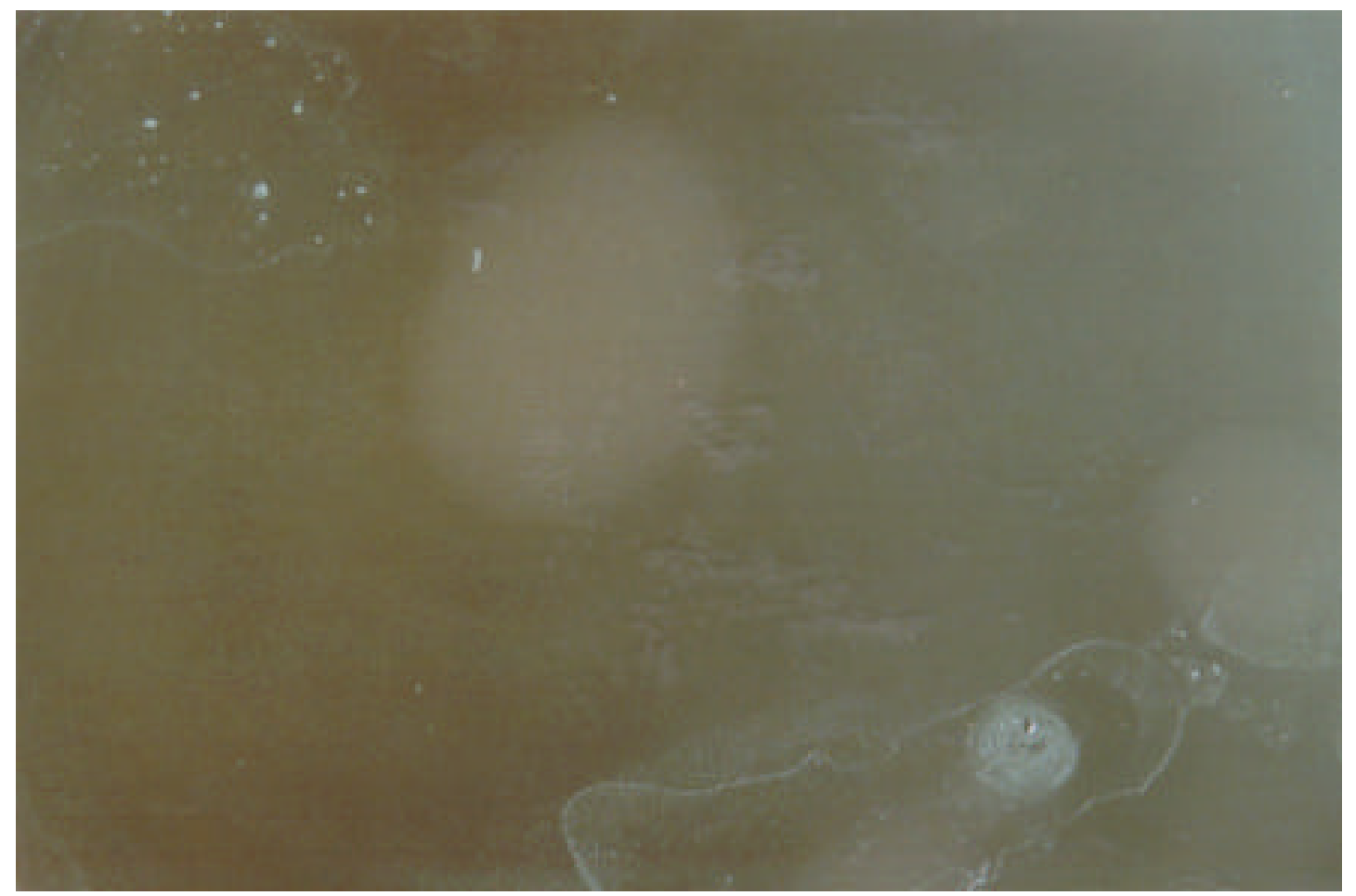

FIGURA 20 A contagem das unidades formadoras de colônias obtidas a partir da diluição $10^{-5}$ no meio CBRCA

\subsection{Análise estatística}

Os parâmetros clínicos foram analisados estatisticamente através do teste de Wilcoxon, entre grupos e intra-grupo. O número de unidades formadoras de colônias $/ \mathrm{mL}$ de placa foram avaliados inicialmente pela ANOVA a dois critérios, levando em consideração os grupos e os períodos em que foram realizadas as avaliações. Também foi realizado o teste de Tukay para verificar em que períodos houveram diferenças estatisticamente 
Material e Métodos 71

significante dentro de cada grupo. Para a comparação dos dois meios de cultura utilizamos o teste de correlação. 
5 RESULTADOS 


\section{RESULTADOS}

Na Tabela 1 são apresentados os valores do índice de placa (IP1), índice gengival ( $\mathrm{IG})$, recessão gengival (R), profundidade de sondagem (PS) e nível de inserção (NI) nos sítios teste e controle de todos os pacientes no início e após 70 dias. Observou-se diminuição do IP1, tanto no sítio controle como no sítio teste, nos pacientes $1,2,3,4,7,9$ e 10, enquanto no paciente 5 não se verificou alteração nesse parâmetro clínico. O IPl do paciente 6 não sofreu alteração no sítio teste e sofreu redução no sítio controle. Já o IPl do paciente 8 permaneceu o mesmo no sítio controle e diminuiu no sítio teste. O IG sofreu redução, tanto no sítio controle como no sítio teste, nos pacientes $1,4,6,7,8,9$ e 10 . No sítio controle do paciente 2 houve redução, porém no sítio teste não sofreu alteração. O IG do sítio teste do paciente 3 permaneceu o mesmo no início e após 70 dias, mas sofreu diminuição no sítio-controle. O paciente 5 apresentou o mesmo IG, tanto no grupo teste como no controle, nos dois períodos avaliados. O paciente 3 não mostrou redução da PS e NI em ambos os sítios comparados e o paciente 2 mostrou redução da PS somente no sítio controle porém, apresentou redução do NI em ambos os sítios. No paciente 9 verificou-se redução do NI no sítio teste e não alteração deste parâmetro clínico no sítiocontrole. Nos demais pacientes verificou-se redução na PS e NI nos sítios teste e controle. Os valores de recessão gengival foram utilizados para obtermos os valores do nível de inserção clínica. 
TABELA 1 Valores dos parâmetros clínicos nos sítios teste e controle no início e após 70 dias

\begin{tabular}{|c|c|c|c|c|c|c|c|c|c|c|c|}
\hline \multirow[b]{2}{*}{ PACIENTE } & \multirow[b]{2}{*}{ SÍTIO } & \multicolumn{5}{|c|}{ INICIO } & \multicolumn{5}{|c|}{ FINAL } \\
\hline & & IPI & $\overline{I G}$ & $\begin{array}{c}\text { PS } \\
(\mathbf{m m})\end{array}$ & $\begin{array}{c}\mathrm{R} \\
(\mathbf{m m})\end{array}$ & $\begin{array}{c}\mathbf{N I} \\
(\mathbf{m m})\end{array}$ & IPI & IG & $\begin{array}{c}\mathrm{PS} \\
(\mathrm{mm})\end{array}$ & $\begin{array}{c}\mathrm{R} \\
(\mathbf{m m})\end{array}$ & $\begin{array}{c}\mathrm{NI} \\
(\mathbf{m m})\end{array}$ \\
\hline \multirow[t]{2}{*}{1} & $\overline{\mathrm{SC}}$ & 2 & 2 & 5,0 & 0,0 & 5,0 & 0 & 1 & 4,0 & 0,0 & 4,0 \\
\hline & ST & 2 & 2 & 5,0 & 0,0 & 5,0 & 1 & 1 & 4,0 & 0,0 & 4,0 \\
\hline \multirow[t]{4}{*}{2} & $\overline{S C}$ & 2 & 2 & $\overline{5,0}$ & 1,0 & 6,0 & $\overline{0}$ & $\overline{0}$ & 4,0 & 1,0 & $\overline{5,0}$ \\
\hline & ST & 2 & 2 & 5,0 & 1,0 & 6,0 & 1 & 2 & 5,0 & 1,0 & 5,0 \\
\hline & $\mathrm{SC}$ & 2 & 3 & 6,0 & 2,0 & 8,0 & 1 & 2 & 6,0 & 2,0 & 8,0 \\
\hline & ST & 2 & 2 & 6,0 & 1,0 & 7,0 & 1 & 2 & 6,0 & 1,0 & 7,0 \\
\hline \multirow[t]{2}{*}{4} & SC & 2 & 2 & 5,0 & 1,0 & 6,0 & 0 & 1 & 4,0 & 1,0 & $\overline{5,0}$ \\
\hline & ST & 2 & 2 & 5,0 & 1,0 & 6,0 & 0 & 1 & 4,0 & 1,0 & 5,0 \\
\hline \multirow[t]{2}{*}{5} & $\overline{\mathrm{SC}}$ & 1 & 2 & 5,0 & 1,0 & 6,0 & 1 & 2 & 4,0 & 1,0 & 5,0 \\
\hline & ST & 1 & 2 & 5,0 & 2,0 & 7,0 & 1 & 2 & 4,0 & 2,0 & 6,0 \\
\hline \multirow[t]{2}{*}{6} & SC & 1 & 2 & $\overline{5,0}$ & 1,0 & 6,0 & 0 & 1 & 4,0 & 1,0 & 5,0 \\
\hline & ST & 1 & 2 & 5,0 & 0,0 & 5,0 & 1 & 1 & 4,0 & 0,0 & 4,0 \\
\hline \multirow[t]{2}{*}{7} & $\mathrm{SC}$ & 1 & 2 & $\overline{5,0}$ & $\overline{0,0}$ & 5,0 & 0 & 0 & 3,0 & $\overline{0,0}$ & 4,0 \\
\hline & ST & 1 & 2 & 5,0 & 1,0 & 6,0 & 0 & 0 & 4,0 & 1,0 & 5,0 \\
\hline \multirow[t]{2}{*}{8} & $\overline{\mathrm{SC}}$ & 1 & 2 & 5,0 & 0,0 & 5,0 & 1 & 1 & 4,0 & 0,0 & 4,0 \\
\hline & ST & 2 & 2 & 5,0 & 0,0 & 5,0 & 1 & 1 & 4,0 & 0,0 & 4,0 \\
\hline \multirow[t]{2}{*}{9} & $\mathrm{SC}$ & 2 & 2 & 5,0 & 0,0 & 5,0 & 0 & 1 & 4,0 & 1,0 & $\overline{5,0}$ \\
\hline & ST & 2 & 2 & 5,0 & 1,0 & 6,0 & 0 & 0 & 3,0 & 1,0 & 4,0 \\
\hline \multirow[t]{2}{*}{10} & $\overline{\mathrm{SC}}$ & 2 & 2 & 5,0 & 1,0 & 6,0 & 0 & 1 & 3,0 & 1,0 & 4,0 \\
\hline & ST & 1 & 2 & 5,0 & 0,0 & 5,0 & 0 & 0 & 3,0 & 1,0 & 4,0 \\
\hline
\end{tabular}

SC: Sítio controle

ST: Sítio teste

IPI: Índice de placa

IG: Índice gengival

PS: Profundidade de sondagem

R: Recessão gengival

NI: nível de inserção clínica

As Tabelas 2, 3 e Figura 21 mostram os valores médios, medianos e desvios-padrão para as variáveis clínicas de índice de placa, índice gengival, profundidade de sondagem e nível de inserção clínica dos dois 
grupo. Na Tabela 2 tem-se a comparação entre os grupos, no início e após a avaliação final (70 dias), utilizando o teste de Wilcoxon, que não revelou diferença estatisticamente significante $(p>0,05)$. Já a Tabela 3 mostra a comparação entre o início e a avaliação final (70 dias) dentro de cada grupo. também utilizando o teste de Wilcoxon, o qual revelou diferença estatisticamente significante $(\mathrm{p}<0,05)$.

TABELA 2 Comparação dos parâmetros clínicos entre os sítios controle e teste nos exames inicial e final

\begin{tabular}{llccccccc}
\hline TEMPO & ÍNDICES & \multicolumn{3}{c}{ SÍTIO CONTROLE } & \multicolumn{3}{c}{ SíTIO TESTE } & P (ns) \\
\hline \multirow{2}{*}{ Inicial } & & Média & Mediana & d.p & Média & Mediana & d.p & \\
& IPl & 1,60 & 2,00 & 0,51 & 1,60 & 2,00 & 0,51 & 1,00 \\
& IG & 2,10 & 2,00 & 0,31 & 2,00 & 2,00 & 0,00 & 1,00 \\
& PS & 5,10 & 5,00 & 0,31 & 5,10 & 5,00 & 0,31 & 1,00 \\
& NI & 5,80 & 6,00 & 0,92 & 5,80 & 6,00 & 0,79 & 1,00 \\
Final & IPl & 0,30 & 0,00 & 0,48 & 0,60 & 1,00 & 0,51 & 0,10 \\
(70dias) & IG & 1,00 & 1,00 & 0,66 & 1,00 & 1,00 & 0,81 & 1,00 \\
& PS & 4,00 & 4,00 & 0,81 & 4,10 & 4,00 & 0,87 & 0,59 \\
& II & 4,90 & 5,00 & 1,20 & 4,80 & 4,50 & 1,03 & 0,68 \\
\hline
\end{tabular}

ns-não significante, teste de Wilcoxon $(\mathrm{p}>0,05)$ 
TABELA 3 Comparação dos parâmetros clínicos dentro dos sítios examinados no início e no final

\begin{tabular}{|c|c|c|c|c|c|c|c|c|}
\hline SÍTIO & ÍNDICES & & INÍCIO & & & FINAL & & $\mathrm{P}$ \\
\hline \multirow{3}{*}{ Controle } & & Média & Mediana & d.p & Média & Mediana & d.p & \\
\hline & IP1 & 1,60 & 2,00 & 0,51 & 0,30 & 0,00 & 0,48 & $0,011^{*}$ \\
\hline & IG & 2,10 & 2,00 & 0,31 & 1,00 & 1,00 & 0,66 & $0,007 *$ \\
\hline \multirow{6}{*}{ Teste } & PS & 5,10 & 5,00 & 0,31 & 4,00 & 4,00 & 0,81 & $0,007 *$ \\
\hline & NI & 5,80 & 6,00 & 0,92 & 5,80 & 6,00 & 0,79 & $0,011^{*}$ \\
\hline & IP1 & 1,60 & 2,00 & 0,51 & 0,60 & 1,00 & 0,51 & $0,011^{*}$ \\
\hline & IG & 2,00 & 2,00 & 0,00 & 1,00 & 1,00 & 0,81 & $0,017 *$ \\
\hline & PS & 5,10 & 5,00 & 0,31 & 4,10 & 4,00 & 0,87 & $0,011 *$ \\
\hline & NI & 4,90 & 5,00 & 1,20 & 4,80 & 4,50 & 1,03 & $0,007^{*}$ \\
\hline
\end{tabular}

*diferença estatisticamente significante, teste de Wilcoxon $(\mathrm{p}<0,05)$ 


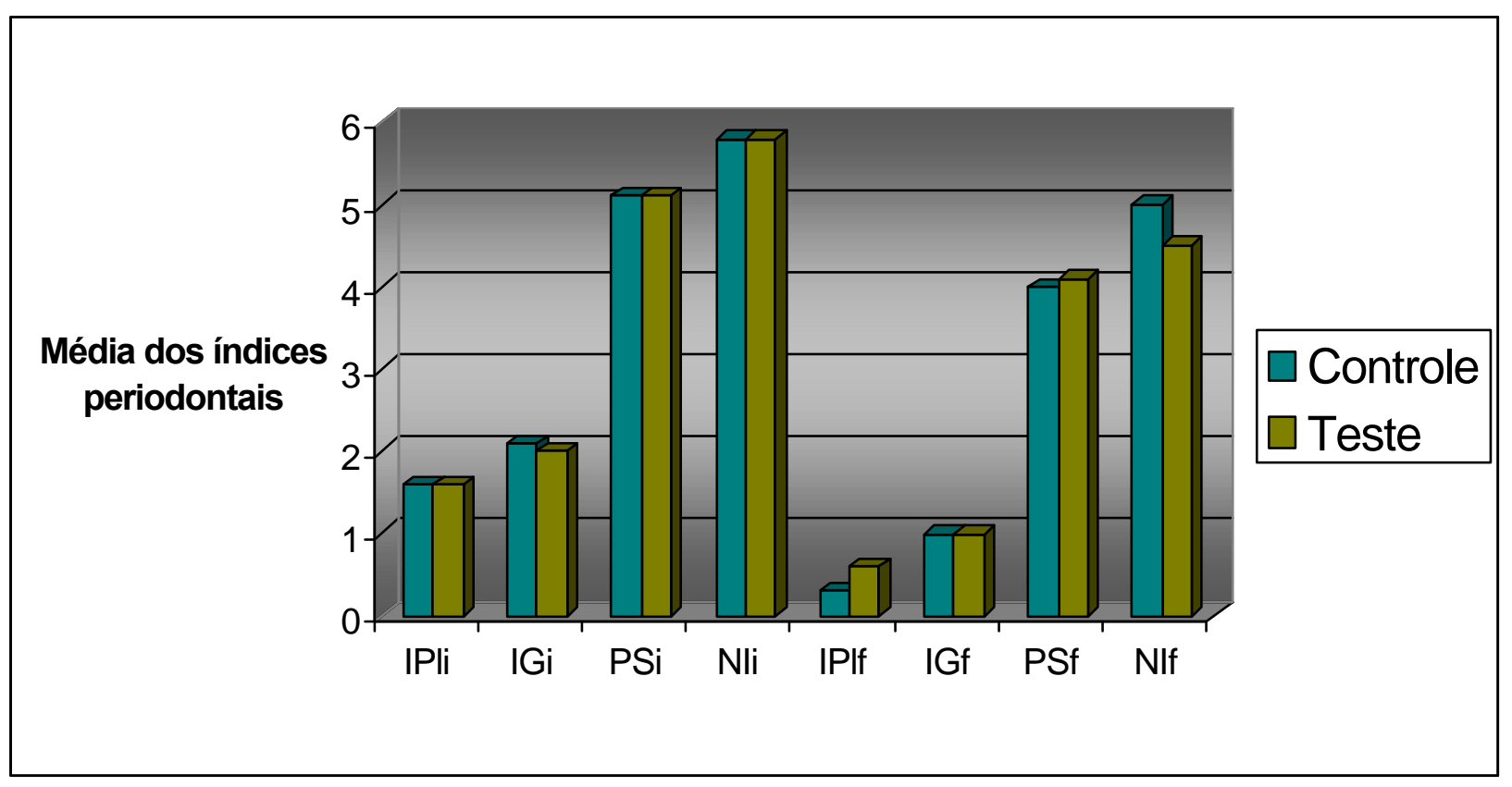

FIGURA 21 Neste gráfico observamos a média do índice de placa inicial (IPli), do índice gengival inicial (IGi), da profundidade de sondagem inicial (PSi), do nível de inserção clínica inicial (NIi), do índice de placa final (IPIf), do índice gengival final (IGf), da profundidade de sondagem final (PSf), do nível de inserção clínica final (NIf) dos sítios dos grupos teste e controle

Na Tabela 4 são demonstrados os valores das contagens das UFC/mL de placa no meio de cultura BYC nos diferentes momentos. Verificou-se que nos dez pacientes analisados, após dez dias, houve redução em todos os sítios-controle; após 40 e 70 dias observou-se o mesmo e somente em dois sítios (pacientes 2 e 5) houve aumento em relação à contagem inicial. Em todos os sítios-teste também verificou-se redução na contagem das UFC/mL de placa após dez dias e 40 dias em relação a contagem inicial, entretanto 
após 70 dias somente um sítio (paciente 5) houve aumento em relação à contagem inicial.

TABELA 4 Valores das contagens das unidades formadoras de colônias/mL de placa no meio BYC

\begin{tabular}{lc|c|c|c|c|c|c|c}
\hline Paciente & \multicolumn{9}{c}{ Tempo } \\
\hline & \multicolumn{2}{c}{ Inicial } & \multicolumn{2}{c}{10 dias } & \multicolumn{2}{c}{40 dias } & \multicolumn{2}{c}{70 dias } \\
& SC & ST & SC & ST & SC & ST & SC & ST \\
\hline 2 & 6,07 & 6,31 & 5,82 & 5,79 & 5,84 & 5,84 & 5,86 & 5,85 \\
\hline 3 & 5,90 & 6,04 & 5,81 & 5,50 & 5,86 & 5,96 & 5,91 & 5,99 \\
\hline 4 & 6,31 & 6,20 & 5,81 & 5,71 & 5,91 & 5,87 & 6,03 & 6,02 \\
\hline 5 & 6,28 & 6,17 & 5,85 & 5,74 & 5,87 & 5,82 & 5,89 & 5,92 \\
6 & 5,95 & 6,00 & 5,67 & 5,56 & 5,80 & 5,74 & 6,13 & 6,05 \\
7 & 5,85 & 5,91 & 4,98 & 5,51 & 5,77 & 5,78 & 5,79 & 5,79 \\
8 & 5,90 & 5,96 & 3,51 & 5,36 & 5,47 & 5,64 & 5,52 & 5,65 \\
9 & 6,26 & 6,39 & 5,72 & 5,54 & 6,00 & 5,94 & 5,94 & 6,13 \\
10 & 5,76 & 5,91 & 4,44 & 4,61 & 5,57 & 3,00 & 5,58 & 4,47 \\
\hline
\end{tabular}

A Tabela 5 relata os valores médios e desvios-padrão da contagem das unidades formadoras de colônias/mL de placa nos sítios teste e controle nos quatro períodos avaliados, quando utilizou-se o meio de cultura BYC, 
TABELA 5 As médias e desvio padrão das contagens das unidades formadoras de colônias/mL de placa dos sítios controle e teste quando se utilizou o meio BYC

\begin{tabular}{lcccc}
\hline TEMPO & \multicolumn{2}{c}{ SÍTIO CONTROLE } & \multicolumn{2}{c}{ SÍTIO TESTE } \\
\hline & Média & d.p. & Média & d.p. \\
\cline { 2 - 5 } Inicial & 6,04 & 0,25 & 6,02 & 0,18 \\
10 dias & 5,20 & 0,82 & 5,33 & 0,41 \\
40 dias & 5,76 & 0,17 & 5,23 & 1,18 \\
70 dias & 5,82 & 0,20 & 5,62 & 0,62 \\
\hline
\end{tabular}

A Figura 22 mostra os valores médios da contagem das UFC/mL de placa entre o sítios teste e controle quando se utilizou o mesmo meio, nos quatro períodos avaliados. Observou-se que, após dez dias, houve redução em ambos os grupos quando comparados aos valores iniciais, porém o grupo-controle mostrou maior redução. Após 40 e 70 dias, notou-se que no grupo controle houve aumento na média da contagem das UFC/mL de placa quando comparado ao valor observado após dez dias, entretanto esses valores permaneceram menores que o valor inicial. $\mathrm{O}$ grupo-teste mostrou redução após 40 dias em relação ao valor observado após dez dias, mas verificou-se que após 70 dias a média do número de $\mathrm{UFC} / \mathrm{mL}$ de placa apresentou valor superior aos valores observados após 10 e 40 dias e continuou inferior ao valor inicial. 


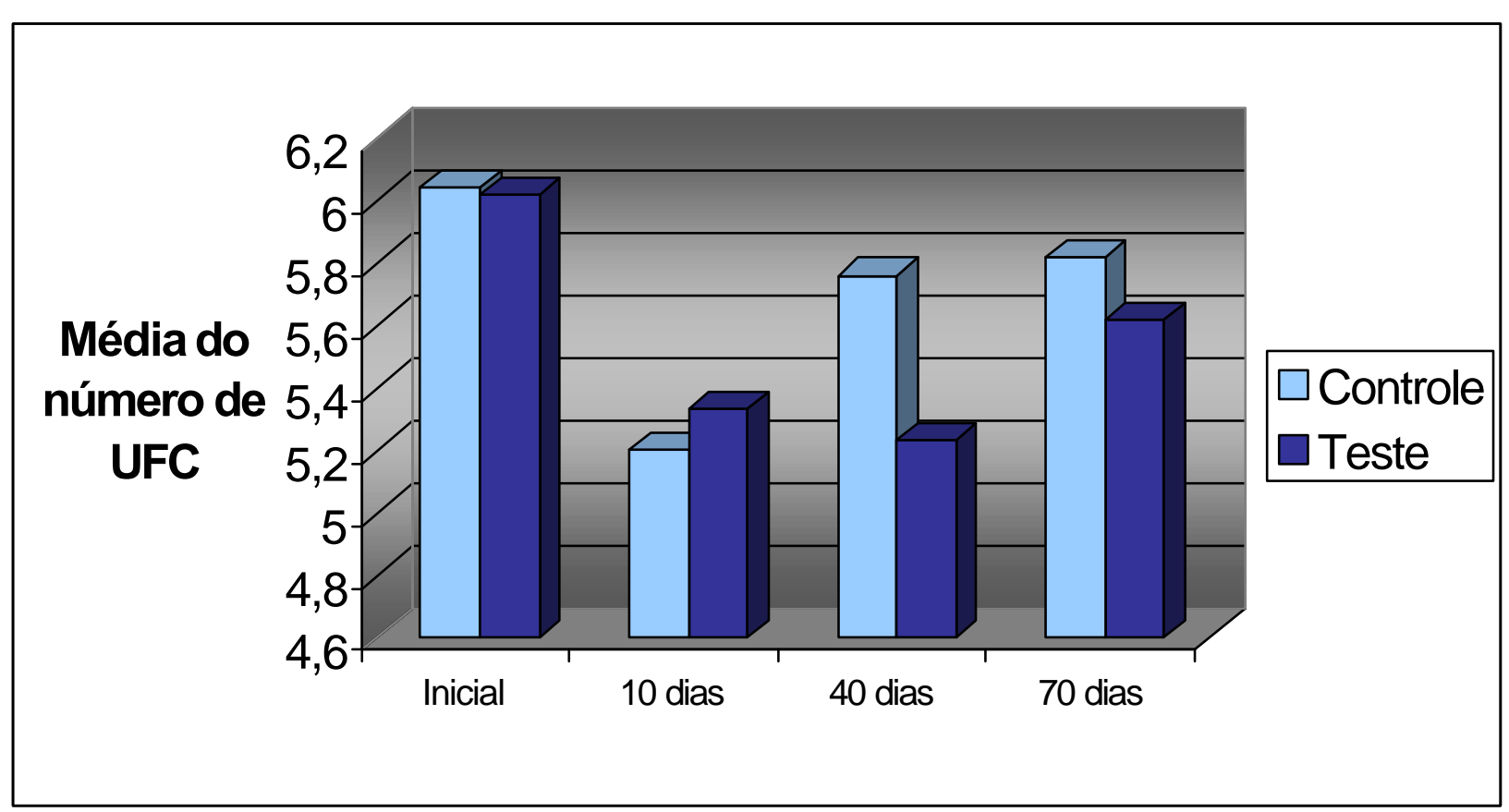

FIGURA 22 O gráfico mostra a média das unidades formadoras de colônias/mL de placa no início e após dez dias, 40 dias e 70 dias do tratamento empregado nos sítios dos grupos teste e controle, quando utilizouse o meio de cultura BYC

Os valores da análise de variança (ANOVA) a dois critérios para verificar o efeito dos dois tratamentos (raspagem e alisamento radicular associados a colocação da pastilha de clorexidina ou somente raspagem e alisamento radicular) ao longo do tempo e nos grupos, quando se utilizou o meio de cultura BYC para a contagem das unidades formadoras de colônias/mL de placa, são mostrados na Tabela 6. Houve diferença estatisticamente significante somente quanto ao tempo (F=14,20; p<0,0001), porém não houve diferença estatisticamente significante quanto 
aos sítios teste e controle $(\mathrm{F}=1,30 ; \mathrm{p}=0,28)$ e nem quanto a interação entre os dois critérios $(F=2,05 ; p=0,13)$.

TABELA 6 Anova a dois critérios para verificar o efeito dos tratamentos no tempo e nos sítios quando utilizou-se o meio BYC

\begin{tabular}{lcccccc}
\hline EFEITO & GL & $\begin{array}{c}\text { QM } \\
\text { (efeito) }\end{array}$ & $\begin{array}{c}\text { GL } \\
\text { (erro) }\end{array}$ & $\begin{array}{c}\text { QM } \\
\text { (erro) }\end{array}$ & F & p \\
\hline TEMPO & 3 & 2,128 & 27 & 0,149 & 14,201 & $0,000010^{*}$ \\
SÍTIO & 1 & 0,492 & 9 & 0,377 & 1,307 & 0,282 \\
INTERAÇÃO & 3 & 0,404 & 27 & 0,196 & 2,053 & 0,129 \\
\hline
\end{tabular}

* Diferença estatisticamente significante $(\mathrm{p}<0,05)$

Na Tabela 7,observam-se as comparações individuais entre os tempos em que utilizou-se o teste de Tukey para comparar os quatro períodos de análise microbiológica quando se utilizou o meio BYC. Verificou-se diferenças estatisticamente significantes entre o exame inicial e aos dez dias; início e aos 40 dias, dez dias e 70 dias, mas não houve diferenças estatisticamente significantes entre o exame inicial e aos 70 dias; aos dez e 40 dias e aos 40 e 70 dias. 
TABELA 7 Comparação entre os quatro períodos de análise microbiológica quando se utilizou o meio BYC

\begin{tabular}{cc}
\hline TEMPO & $\mathrm{p}$ \\
\hline Inicio X 10 dias & $0,00017^{*}$ \\
Inicio X 40 dias & $0,00115^{*}$ \\
Inicio X 70 dias & $0,08006 \mathrm{~ns}$ \\
10 dias X 40 dias & $0,2342 \mathrm{~ns}$ \\
10 dias X 70 dias & $0,00467^{*}$ \\
40 dias X 70 dias & $0,2948 \mathrm{~ns}$ \\
\hline
\end{tabular}

* Diferença estatisticamente significante $(\mathrm{p}<0,05)$

ns Não significante

Os valores das contagens das unidades formadoras de colônias (UFC/mL de placa) no meio CBRCA estão expressos na Tabela 8. Verificou-se que nos sítios-controle dos dez pacientes analisados após dez e 40 dias houve redução do número de $\mathrm{UFC} / \mathrm{mL}$ de placa em comparação aos dados iniciais e após 70 dias, somente um sítio (paciente 5) mostrou aumento em relação à contagem inicial. Em todos os sítios-teste dos dez pacientes analisados também observou-se redução em comparação aos dados iniciais. Após 40 dias observou-se o mesmo e somente em um sítio (paciente 3) houve aumento em relação à contagem inicial. Após 70 dias, somente dois sítios (pacientes 3 e 5) mostraram aumento em relação à contagem inicial. 
TABELA 8 Valores das contagens das unidades formadoras de colônias no meio CBRCA

\begin{tabular}{lc|c|c|c|c|c|c|c}
\hline Paciente & \multicolumn{9}{c}{ Tempo } \\
\hline & \multicolumn{2}{c}{ Inicial } & \multicolumn{2}{c}{10 dias } & \multicolumn{2}{c}{40 dias } & \multicolumn{2}{c}{70 dias } \\
& SC & ST & SC & ST & SC & ST & SC & ST \\
\hline 2 & 6,17 & 6,32 & 5,80 & 5,76 & 5,85 & 5,82 & 5,94 & 5,90 \\
\hline 3 & 5,92 & 5,90 & 5,55 & 5,50 & 5,56 & 5,89 & 5,64 & 5,88 \\
\hline 4 & 6,31 & 5,88 & 5,81 & 5,77 & 5,91 & 5,99 & 6,03 & 6,05 \\
\hline 5 & 6,28 & 6,33 & 5,85 & 5,87 & 5,87 & 5,80 & 5,89 & 5,97 \\
6 & 5,95 & 6,05 & 5,67 & 5,63 & 5,80 & 5,99 & 6,13 & 6,10 \\
\hline 7 & 5,85 & 5,90 & 4,98 & 5,04 & 5,77 & 5,74 & 5,79 & 5,75 \\
8 & 5,90 & 6,00 & 3,51 & 5,46 & 5,47 & 5,43 & 5,52 & 5,64 \\
\hline 9 & 6,26 & 6,34 & 5,72 & 5,45 & 6,00 & 5,80 & 5,94 & 5,97 \\
\hline 10 & 5,76 & 5,33 & 4,44 & 4,72 & 5,57 & 3,72 & 5,58 & 4,12 \\
\hline
\end{tabular}

Na Tabela 9 demonstra-se os valores médios e desvios-padrão da contagem das unidades formadoras de colônias dos sítios teste e controle, nos quatro períodos avaliados, quando utilizou-se o meio de cultura CBRCA 
TABELA 9 As médias das contagem das unidades formadoras de colônias/mL de placa dos sítios controle e teste quando se utilizou o meio CBRCA

\begin{tabular}{lcccc}
\hline TEMPO & \multicolumn{2}{c}{ SiTIO CONTROLE } & \multicolumn{2}{c}{ SiTIO TESTE } \\
\hline & Média & d.p. & Média & d.p. \\
\cline { 2 - 5 } Inicial & 5,99 & 0,24 & 5,89 & 0,34 \\
10 dias & 5,17 & 0,78 & 5,34 & 0,40 \\
40 dias & 5,60 & 0,44 & 5,36 & 0,88 \\
70 dias & 5,71 & 0,38 & 5,52 & 0,75 \\
\hline
\end{tabular}

A Figura 23 mostra os valores médios da contagem das UFC/mL de placa dos sítios teste e controle quando se utilizou o meio CBRCA, nos quatro períodos avaliados. Observou-se que após 10 dias houve redução em ambos os sítios quando comparados aos valores iniciais, porém os sítioscontrole mostraram maior redução. Após 40 e 70 dias notou-se que nos sítios controle e teste houve um aumento na média da contagem das UFC/mL de placa quando comparados aos valores observados após dez dias, entretanto esses valores permaneceram inferiores aos valores iniciais. 


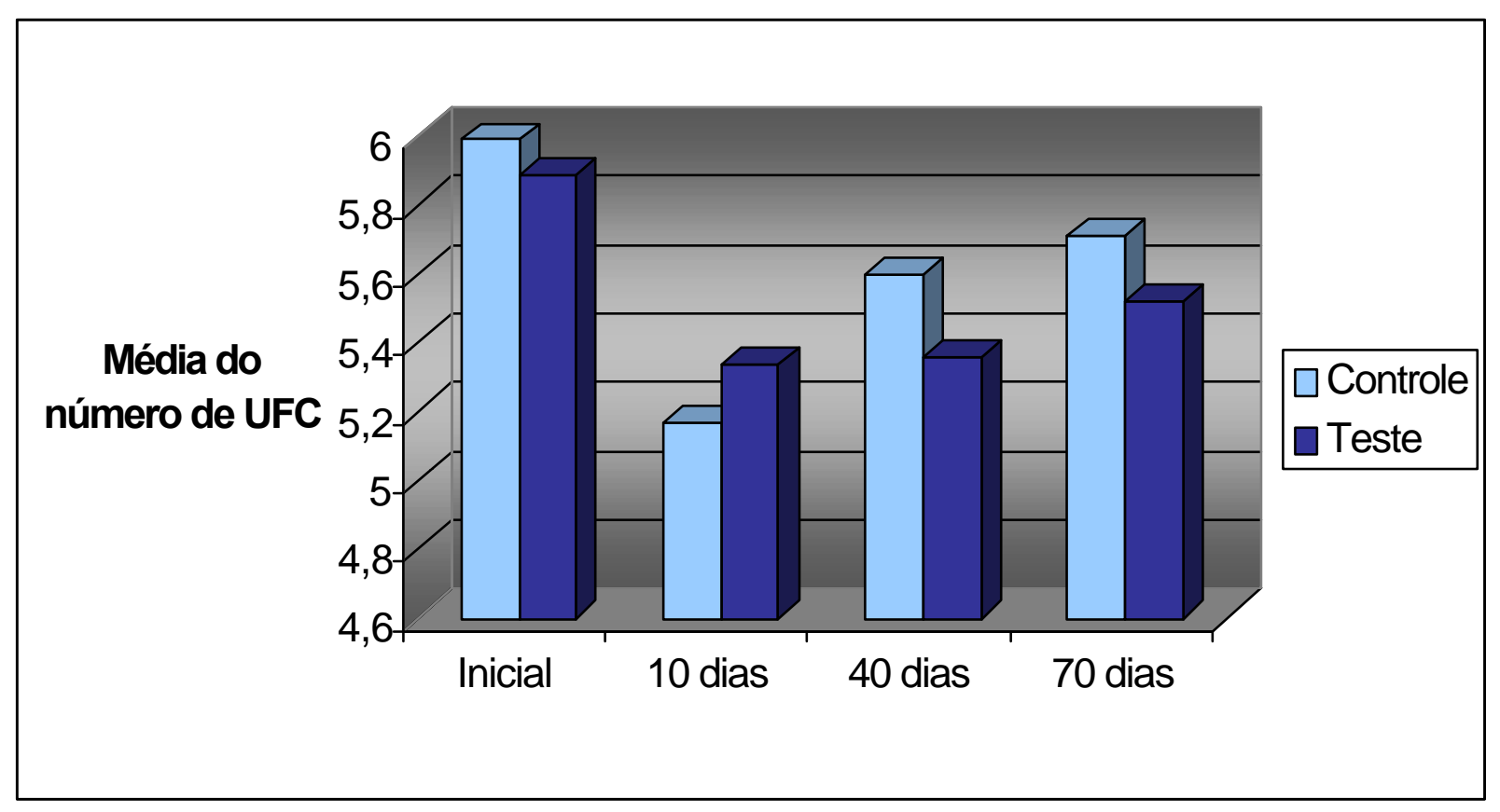

FIGURA 23 Neste gráfico observa-se a média das unidades formadoras de colônias/mL de placa nos exames inicial, aos dez , 40 e 70 dias do tratamento empregado para os grupos controle e teste

Os valores da análise de variança (ANOVA) a dois critérios para verificar o efeito dos dois tratamentos comparados (raspagem e alisamento radicular associados à colocação da pastilha de clorexidina ou somente raspagem e alisamento radicular) ao longo do tempo e nos diferentes sítios, quando se utilizou o meio de cultura CBRCA para a contagem das unidades formadoras de colônias/mL de placa, são mostrados na Tabela 10. Houve diferença estatisticamente significante somente em relação ao tempo de avaliação $(\mathrm{F}=11,93 ; \mathrm{p}<0,0001)$, porém não houve diferença estatisticamente 
significante quanto aos sítios teste e controle $(\mathrm{F}=0,77 ; \mathrm{p}=0,40)$ e nem quanto a interação entre os dois critérios $(\mathrm{F}=2,13 ; \mathrm{p}=0,12)$

TABELA 10 Anova a dois critérios para verificar o efeito dos tratamentos no tempo e nos sítios quando utilizou-se o meio CBRCA

\begin{tabular}{lcccccc}
\hline EFEITO & GL & $\begin{array}{c}\text { QM } \\
\text { (efeito) }\end{array}$ & $\begin{array}{c}\text { GL } \\
\text { (erro) }\end{array}$ & $\begin{array}{c}\text { QM } \\
\text { (erro) }\end{array}$ & F & $p$ \\
\hline TEMPO & 3 & $1,636^{*}$ & $27^{*}$ & $0,137^{*}$ & $11,928^{*}$ & $0,000037^{*}$ \\
SÍTIO & 1 & 0,172 & 9 & 0,224 & 0,765 & 0,404 \\
INTERAÇÃO & 3 & 0,167 & 27 & 0,078 & 2,130 & 0,119 \\
\hline
\end{tabular}

* Diferença estatisticamente significante $(\mathrm{p}<0,05)$

A Tabela 11 mostra as comparações individuais entre os tempos da análise microbiológica pelo teste de Tukey quando se utilizou o meio CBRCA. Verificou-se diferença estatisticamente significante quando se compararam início e dez dias; início e 40 dias; início e 70 dias; dez dias e 70 dias, mas não houve diferença estatisticamente significante quando se compararam 10 e 40 dias; 40 dias e 70 dias. 
TABELA 11 Comparação entre os quatro períodos de análise microbiológica quando se utilizou o meio CBRCA, nos sítios teste e controle

\begin{tabular}{cc}
\hline TEMPO & $\mathrm{p}$ \\
\hline Inicio X 10 dias & $0,0002^{*}$ \\
Inicio X 40 dias & $0,0030^{*}$ \\
Inicio X 70 dias & $0,00492^{*}$ \\
10 dias X 40 dias & $0,2468 \mathrm{~ns}$ \\
10 dias X 70 dias & $0,0225^{*}$ \\
40 dias X 70 dias & $0,6455 \mathrm{~ns}$ \\
\hline
\end{tabular}

* Diferença estatisticamente significante $(\mathrm{p}<0,05)$

ns Não significante

Ao compararmos os dois meios utilizados no presente estudo, BYC e CBRCA, através do teste de correlação, observamos uma correlação positiva $(\mathrm{r}=0,93)$ o que significa que ambos os meios foram comparáveis para a contagem das UFC/mL de placa (Figura 24) 


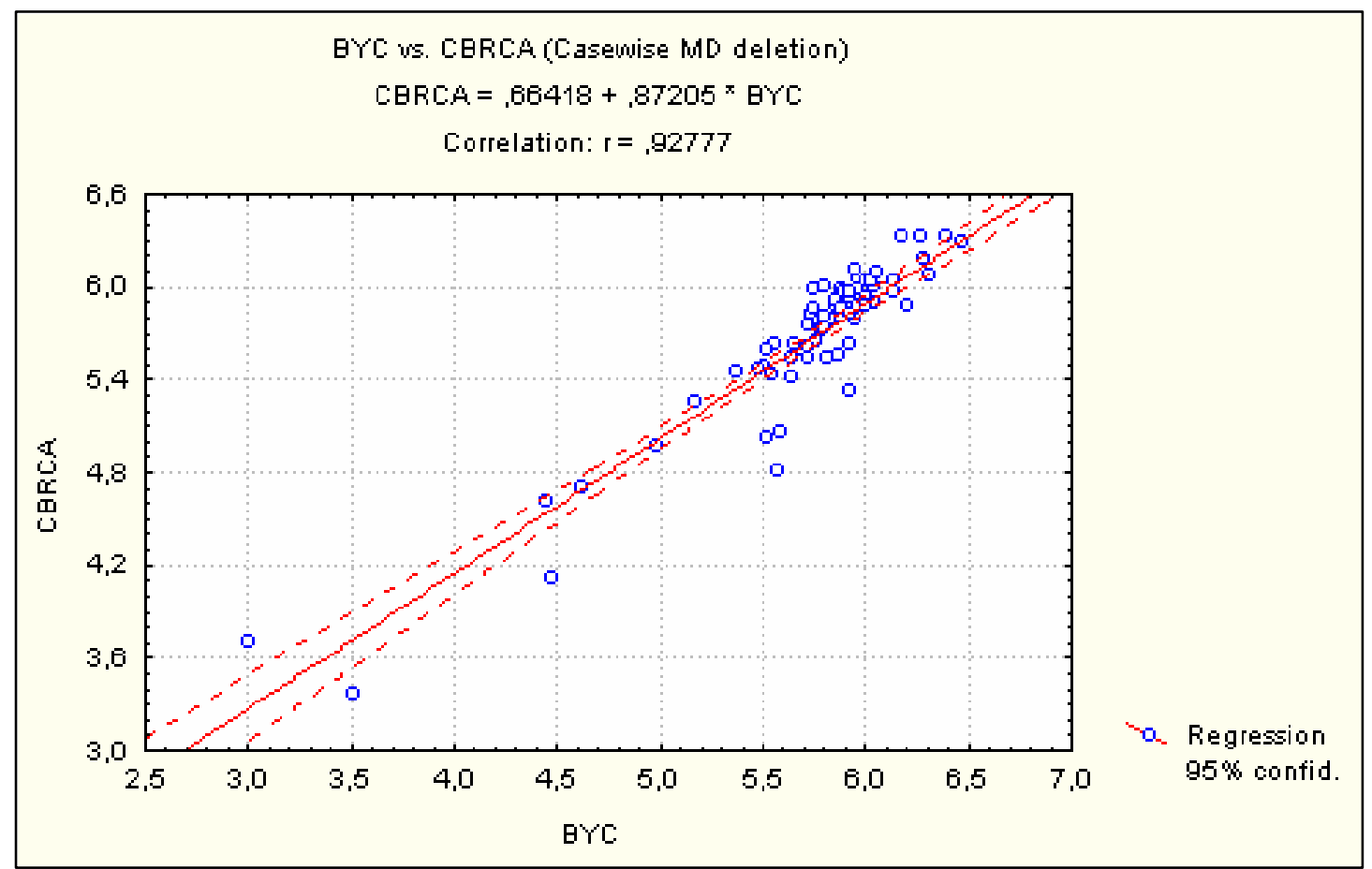

FIGURA 24 Neste gráfico, observamos uma correlação positiva $(r=0,93)$, $\mathrm{p}<0,001$ quando realizamos o teste de correlação para compararmos a eficácia dos meios BYC e CBRCA quando na realização da contagem das $\mathrm{UFC} / \mathrm{mL}$ de placa 


\section{DISCUSSÃO}

A presença de microrganismos na placa bacteriana é fundamental para o início e desenvolvimento das doenças

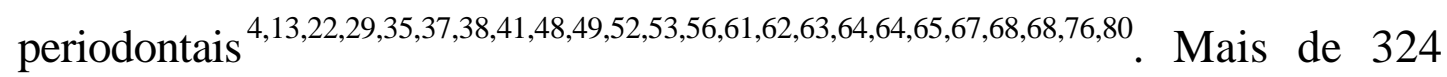
espécies bacterianas podem ser cultivadas de amostras obtidas do sulco gengival ou de bolsa periodontal ${ }^{54}$, sendo que algumas espécies bacterianas parecem estar mais freqüentemente associadas a certos tipos específicos de doença periodontal ${ }^{65}$.

Para KELSTRUP; THEILADE ${ }^{29}$, em 1974, toda doença periodontal seria iniciada com uma gengivite que eventualmente evolui para uma periodontite. De acordo com o conceito de placa específica, diferenças em sua composição poderiam explicar as variações no padrão de destruição do periodonto. Além disso, dscutia-se o fato de que se encontrava gengivite associada a grande quantidade de placa sem evoluir para periodontite, enquanto outros sítios com pouca quantidade de placa e inflamação clínica levavam a uma rápida perda de inserção ${ }^{67}$. Assim, o uso de técnicas de avaliação microbiológica mostrou diferenças na composição da placa bacteriana supra e subgengival, associando-as à saúde, à gengivite e à periodontite.

Determinadas espécies bacterianas parecem estar relacionadas à doença periodontal destrutiva, onde mais de um tipo de microrganismos pode iniciar a destruição periodontal ${ }^{64}$. Em áreas saudáveis tem-se predominância de cocos e bastonetes Gram positivos, enquanto nos locais com gengivite encontram-se principalmente cocos, bastonetes, 
filamentosos e fusiformes ${ }^{37,41}$ e na presença da doença avançada encontrase um grande número de espiroquetas ${ }^{37}$.

Não basta a presença de placa bacteriana em contato com o periodonto, mas é necessário a presença de bactérias periodontopatogênicas para causar a doença periodontal como o Actinobacillus actinomycetemcomitans ${ }^{13,2252,61,62,66,80}$, Porphyromonas gingivalis (Bacteroides gingivalis) 2,11,13,19,20,22,35,52,55,59,61,62,66,76,79,80, Prevotella intermedia (Bacteroides intermedius) ${ }^{2,13,19,22,52,55,59,62,66,80}$, Fusobacterium nucleatum ${ }^{2,13,55,59,66,79}$, Eikenella corrodens ${ }^{13,55,66,80}$, Bacteroides forsythus ${ }^{13,20,67}$, Peptostreptococus micros ${ }^{13,58,66}$, Campylobacter rectus ${ }^{13,66}$, Treponema denticola ${ }^{13,76}$, Treponema socranskii ${ }^{76}$, Pseudomonas, Selenomonas e Staphylococcus ${ }^{13}$. Entretanto, para GENCO et al. ${ }^{13}$, em 1998, somente a presença de uma ou mais espécies patogênicas não estaria necessariamente associada à progressão da doença, em parte devido à resposta do hospedeiro e em parte devido à interação entre os diferentes tipos de microrganismos, alguns dos quais poderiam promover o desenvolvimento de patógenos primários, enquanto outros poderiam inibir o seu crescimento.

Além da participação dos microrganismos na etiologia das doenças periodontais, a resposta do hospedeiro frente à agressão destes microrganismos deve ser levada em consideração, pois as bactérias associadas à doença periodontal produzem enzimas que podem destruir os tecidos ou interferir com a atividade de defesa do hospedeiro ${ }^{50}$. Substâncias tóxicas e metabólitos de baixo peso molecular são constantemente liberados dos biofilmes e vão promover efeitos deletérios diretamente sobre o epitélio, podendo penetrar no tecido conjuntivo, interagindo com pequenos vasos e células do hospedeiro, induzindo ao processo 
inflamatório $^{56}$. A inflamação pode promover a destruição tecidual devido à liberação de enzimas proteolíticas provenientes de células fagocitárias e outras células do hospedeiro ${ }^{50}$. Citocinas provenientes da inflamação como, IL-1 $\beta$, TNF- $\alpha$, IFN- $\gamma$, induzem e aumentam a produção de prostaglandinas, principalmente $\mathrm{PGE}_{2}$, que vão mediar a reabsorção do osso alveolar e enzimas conhecidas como matriz metaloproteases (MMPs) vão mediar a destruição dos componentes da matriz extracelular da gengiva e do ligamento periodontal, sendo os macrófagos e os fibrobastos a principal fonte de $\mathrm{PGE}_{2}$ e MMPs ${ }^{56}$. Além disso, substâncias citotóxicas bacterianas, linfocinas, provavelmente afetam a capacidade dos fibroblastos em manter a formação de fibras colágenas ${ }^{29}$.

A susceptibilidade do hospedeiro e condições ambientais locais associados a determinadas bactérias podem promover a perda de inserção progressiva $^{79}$.

Segundo RAMS; SLOTS ${ }^{58}$, em 1996, as doenças periodontais podem ser controladas pela supressão de algumas espécies de microrganismos da placa subgengival que são consideradas patogênicas e pela interferência na recolonização destes sítios por estas bactérias. Com o intuito de bloquear ou ao menos retardar a progressão da doença periodontal que resulta na destruição dos tecidos de suporte os procedimentos de raspagem e alisamento radicular são considerados a conduta principal no tratamento destas infecções ${ }^{28}$. No entanto, tem-se observado que o debridamento mecânico/cirúrgico usualmente não erradica microrganismos periodontopatogênicos devido ao seu potencial invasivo para as células epiteliais e tecido conjuntivo subepitelial. Além disso, a recolonização da microbiota subgengival após raspagem e alisamento radicular pode ocorrer após vários meses, particularmente quando 
associados ao controle da placa subgengival, sendo que algumas espécies bacterianas recolonizam bolsas periodontais profundas após 140 a 224 dias a despeito de múltiplas sessões de raspagem e alisamento radicular e controle de placa meticuloso ${ }^{47}$, presumivelmente devido a presença de placa bacteriana residual não removida pelo debridamento mecânico. Com o intuito de intensificar a ação da raspagem e alisamento radicular no tratamento das periodontites foi proposto o emprego de agentes antimicrobianos sistêmicos ${ }^{58}$ e tópicos como irigação do sulco gengival e a colocação de dispositivos de liberação lenta ${ }^{36,46,58}$.

Agentes antimicrobianos podem ganhar acesso à bolsa periodontal tanto através da administração sistêmica quanto local, entretanto quando sistemicamente empregados promovem uma exposição de todos os sítios periodontais ao medicamento e possibilitam um risco maior de reações adversas em outras áreas do corpo ${ }^{58}$. De acordo com GREENE $^{17}$, em 1997, vários fatores podem influenciar a eficácia de um antibiótico nas áreas periodontais como, susceptibilidade dos patógenos para a droga utilizada, ligação da droga aos tecidos, ligação ou consumo da droga pelos microrganismos considerados não alvos, que protegeriam os periodontopatógenos, capacidade de alguns microrganismos invadirem os tecidos periodontais, conferindo inacessibilidade aos antibióticos colocados subgengivalmente, o total de bactérias na bolsa periodontal poderia exceder a concentração máxima do antibiótico, sendo insuficiente para eliminar todas as bactérias presentes, alguns antibióticos são bacteriostáticos, mas não necessariamente erradicam os patógenos, os microrganismos patogênicos podem residir na mucosa bucal, língua, tonsilas ou a superfície da gengiva permanecendo inacessíveis aos antibióticos que são secretados no fluido gengival, algumas bactérias 
podem inativar o antibiótico por atividade enzimática, por exemplo, uma beta-lactamase que destrói a atividade do anel beta-lactâmico do antibiótico, a microbiota subgengival pode ser considerada como um biofilme e apresentar maior resistência à ação dos antibióticos. Também salientou que a antibioticoterapia sistêmica alcança baixa dosagem no fluido gengival, pode provocar efeitos colaterais adversos e promover uma superinfecção com outros microrganismos.

A irrigação subgengival apresenta as vantagens de ser de fácil aplicação pelo profissional e apresentar alta concentração, porém tem desvantagens como difícil aplicação pelo paciente, rápida eliminação e necessidade de repetidas aplicações ${ }^{46}$. Diferentes soluções têm sido utilizadas através de irrigações via bolsa periodontal tanto pelo profissional como pelo paciente como coadjuvante no tratamento de periodontites, como por exemplo, soluções de clorexidina, hipoclorito de sódio, bicarbonato de sódio, peróxido de hidrogênio, iodo-polvidine, fluoreto estanhoso e tetraciclina-HCL ${ }^{58}$. MACALPINE et al. ${ }^{43}$, em 1985, ao comparar 64 sítios irrigados com clorexidina $2 \%$, tetraciclina $50 \mathrm{mg} / \mathrm{ml}$, solução salina fisiológica após raspagem e alisamento radicular não verificaram diferenças estatisticamente significantes em relação à profundidade de sondagem, índice de sangramento, nível de inserção clínica e o número de espiroquetas.

Em outro estudo, irrigações com diferentes soluções de clorexidina $(0,12 \%, 0,04 \%$,$) e com água foram realizadas tanto pelo profissional como$ pelo paciente e comparados seus efeitos após três meses, verificou-se não existirem diferenças estatisticamente significantes entre os grupos que receberam irrigação, entretanto houve melhora clínica nestes grupos ${ }^{27}$. Já FINKELMAN; WILLIAMS ${ }^{12}$, em 1998, constataram que os bochechos 
com clorexidina foram efetivos no tratamento de gengivite, porém não para as periodontites, presumivelmente pela baixa penetração deste agente na bolsa periodontal. A dificuldade em manter uma concentração suficiente deste agente por um período adequado de tempo através de repetidas irrigações não favoreceu o seu emprego nas terapias periodontais.

Um adequado tempo de contato entre o agente antimicrobiano e os microrganismos deveria ser atingido para exercer os efeitos bacteriostáticos ou bactericidas $^{21}$. O volume total de fluido gengival em uma bolsa periodontal apresenta um "turnover" de aproximadamente 40 vezes em uma hora, o que é mais freqüente que a velocidade de "turnover" salivar na cavidade bucal que é de 28 vezes em 1 hora ${ }^{16,21}$. Dessa forma, o rápido desaparecimento do agente antimicrobiano da bolsa periodontal aplicado através de irrigações limita a sua eficácia, ou seja, a sua deficiência clínica é provavelmente resultante do curto período de tempo que a solução irrigadora permanece no ambiente periodontal.

Algumas características deveriam ser consideradas na escolha de um sistema de liberação local na terapia periodontal como: alcançar o sítio da doença (base da bolsa), atingir concentração adequada, ser mantido no local por um período adequado de tempo durante o tratamento, ser efetivo contra patógenos periodontais, ser clinicamente efetivo como terapia coadjuvante, seguro para os dentes e tecidos moles, ter efeitos colaterais adversos mínimos, não causar resistência bacteriana, ser de fácil aplicação e biodegradável ${ }^{5,26,33}$.

Os dispositivos de liberação lenta são considerados seguros e eficazes, e mantêm o princípio ativo em alta concentração e por tempo prolongado no local da infecção periodontal ${ }^{25,26,33,46}$, podendo se apresentarem sob a forma de tubos, géis, fibras, polímeros e pastilhas nos 
quais diferentes agentes antimicrobianos têm sido empregados como por exemplo, metronidazol, minociclina, tetraciclina, doxiciclina e clorexidina $^{5,12,17,33,34,45,58}$. Fibras ou fitas não degradáveis de tetraciclina (Actisite $®)$, géis de minociclina (Periocline $\left.{ }^{\circledR}\right)$ e metronidazol (Elyzol ${ }^{\circledR}$ ), sistema pó-líquido de doxiciclina (Atridox ${ }^{\circledR}$ ) e pastilhas de clorexidina (Periochip®) são alguns exemplos de sistemas de liberação lenta utilizados atualmente em periodontia ${ }^{5,12,33,34,46}$.

Os sistemas de liberação lenta também apresentam como vantagens aplicações menos freqüentes e maior aceitação pelo paciente e como desvantagem a sua aplicação ser realizada somente pelo profissional ${ }^{46}$. Para KILLOY; SAIKI ${ }^{34}$, em 1999, os sistemas de liberação lenta são métodos que quando associados aos procedimentos de raspagem e de alisamento radicular dão melhores resultados clínicos, pois, eliminam diretamente as bactérias presentes, prolongam o tempo para que ocorra a reinfecção, permitindo ao profissional tratar de modo mais eficiente a forma recorrente dessa doença, por atuar sobre os microrganismos que não sofreram a ação mecânica dos procedimentos básicos de periodontia, aumentando a probabilidade de sucesso deste tratamento, sem a necessidade de uma terapia cirúrgica.

A clorexidina é um antimicrobiano que tem sido usado como coadjuvante na terapia periodontal. Quando usada em baixas concentrações age como bacteriostático por causar o aumento da permeabilidade da membrana e o extravasamento de substâncias de baixo peso molecular, especificamente fósforo e potássio, e quando em altas concentrações atua como bactericida por induzir a precipitação do conteúdo citoplasmático bacteriano e morte celular ${ }^{15,18}$. Apresenta uma molécula catiônica o que lhe confere adsorção aos substratos aniônicos como hidroxiapatita, película de 
glicoproteínas salivares e membranas das células das mucosas, possibilitando uma maior retenção, lenta liberação e consequentemente um efeito mais prolongado ${ }^{18}$. Também apresenta amplo espectro atuando contra microrganismos Gram positivos e Gram negativos ${ }^{15,18}$, porém é considerada mais efetiva contra bactérias Gram positivas ${ }^{15}$ e não provoca resistência bacteriana ${ }^{15,17,18}$.

A ação da clorexidina "in vitro" testada em bactérias subgengivais de pacientes com periodontite crônica foi considerada efetiva contra espécies de Selenomonas sputigena, Bacteroides gingivalis e Bacteroides intermedius frente a diferentes diluições da solução de gluconato de clorexidina a 0,2\%, entretanto frente as cepas de Fusobacterium nucleatum, Streptococcus sanguis, Streptococcus mitior e Capnocytophaga apresentou relativa eficácia ${ }^{78}$. Como em nosso estudo não identificamos os microrganismos, não pudemos avaliar a ação da clorexidina frente aos periodontopatógenos específicos.

Nesta pesquisa avaliamos a utilização de um dispositivo de liberação lenta contendo clorexidina como coadjuvante aos procedimentos de raspagem e alisamento radicular em pacientes com periodontite crônica. Este dispositivo (PerioChip ${ }^{\circledR}$ ) contem 2,5mg de gluconato de clorexidina em uma matriz de gelatina biodegradavel, apresentando a forma retangular, de cor laranja escuro, arredondado em um dos lados e medindo aproximadamente $4 \times 5 \times 0,35 \mathrm{~mm}^{5,26,31,32,33,34}$. Os indivíduos selecionados para este estudo apresentavam periodontite crônica com bolsas periodontais com profundidade de sondagem inicial entre $5 \mathrm{~mm}$ e $6 \mathrm{~mm}$, portanto dentro dos padrões recomendados para a colocação da pastilha de clorexidina, ou seja bolsas com profundidade de sondagem $\geq$ $5 \mathrm{~mm}^{5,31,32,33,34}$. Além disso, não havendo necessidade de uma nova visita 
para sua remoção os paciente foram instruídos a não usar escova ou fio dental nas áreas tratadas para evitar o deslocamento da pastilha conforme recomendação de vários estudos ${ }^{5,6,31,32,33}$.

Após a inserção do PerioChip ${ }^{\circledR}$ na bolsa periodontal o pico de concentração da clorexidina liberada no interior da bolsa nas primeiras horas é de $2000 \mu \mathrm{g} / \mathrm{mL}$, diminuindo progressivamente, entretanto os níveis variam de 1300 a $1900 \mu \mathrm{g} / \mathrm{mL}$ após quatro dias e permanecem acima de $125 \mu \mathrm{g} / \mathrm{mL}$ por mais de oito dias ${ }^{71}$. Essa concentração é considerada inibitória para espiroquetas e microrganismos móveis conforme o estudo realizado por STANLEY; WILSON; NEWMAN ${ }^{75}$, em 1989, no qual foram avaliadas 50 culturas puras de bactérias e 25 amostras de placa subgengival de pacientes com periodontite crônica observando-se que a concentração inibitória mínima (MIC) da clorexidina para culturas puras variou de 8 a $500 \mu \mathrm{g} / \mathrm{ml}$ com valor médio de $62 \mu \mathrm{g} / \mathrm{ml}$ tendo inibido $64 \%$ das cepas . Em relação às amostras da placa subgengival verificou-se que a MIC variou de 31 a $250 \mu \mathrm{g} / \mathrm{ml}$, com o valor médio de $125 \mu \mathrm{g} / \mathrm{ml}$ de clorexidina que foi capaz de inibir 99\% da microbiota subgengival. Assim, a pastilha de clorexidina libera uma concentração efetiva por um período de oito dias, ao contrário do uso de irrigações que não mantém o agente antimicrobiano por tempo adequado dentro da bolsa.

O PerioChip ${ }^{\circledR}$ possui muitas características de um agente coadjuvante ideal ao tratamento periodontal por ser de fácil uso, podendo ser colocado na bolsa periodontal aproximadamente em 20 segundos, não sendo necessário sua remoção por ser biodegradável e sua recolocação é recomendada a cada três meses ${ }^{25,26,39}$. Este dispositivo promoveria uma liberação lenta de clorexidina, entretanto, não deveria ser recomendado a 
sua inserção em sítios com abscesso periodontal, pois a pastilha se expande e bloqueia a via de drenagem do abscesso o que poderia resultar em aumento do desconforto do paciente durante as primeiras 24 horas ${ }^{6}$.

JEFFCOAT et al. ${ }^{25}$, em 1998, relataram em um estudo multicentro com 447 pacientes, que reações adversas leves e moderadas poderiam ser observadas, entretanto em nossa pesquisa, ao realizarmos a anamnese, nenhum dos dez pacientes relatou desconforto ou alguma reação adversa. Podemos afirmar que o colocação do PerioChip ${ }^{\circledR}$ é uma manobra clínica simples e fácil, confirmando os resultados obtidos por MACNEIL et al. ${ }^{45}$, em 1998, através de um questionário, o qual foi respondido por estudantes, técnicos em higiene dentária e dentistas e higienistas com experiência profissional que participaram da colocação deste dispositivo em 52 pacientes com periodontite do adulto.

Vários estudos que utilizaram o PerioChip ${ }^{\circledR}$ como coadjuvante aos procedimentos de raspagem e alisamento radicular em pacientes com periodontite do adulto com bolsas periodontais entre 5 e $8 \mathrm{~mm}$, demonstraram haver mudanças mais favoráveis no índice gengival, profundidade de sondagem e nível de inserção clínica do que nos pacientes em que somente foram realizados os procedimento de raspagem e alisamento radicular $^{24,25,26,39,71,73}$ ou que receberam uma pastilha placebo $^{25,26}$. Ao contrário, em nosso trabalho, os parâmetros clínicos adotados mostraram que houve redução na média do índice de placa, do índice gengival, profundidade de sondagem e nível de inserção, mas estes resultados favoráveis foram encontrados tanto nos sítios-teste como nos sítios controle. Para a comparação dos parâmetros clínicos entre os grupos, no inicio e após 70 dias utilizou-se o teste de Wilcoxon o qual não revelou diferença estatisticamente significante (p>0,05) (Tabela 2 e Figura 21). O 
mesmo teste foi utilizado para a comparação dos parâmetros clínicos para cada grupo individualmente no início e após 70 dias, revelando diferença estatisticamente significante $(\mathrm{p}<0,05)$ conforme os dados apresentados na Tabela 3 e Figura 21.

Em nosso estudo, somente o paciente 3 não mostrou redução na profundidade de sondagem, nível de inserção e no índice de placa e houve manutenção do sangramento à sondagem em ambos os sítios comparados. O paciente 2 apresentou redução no índice de placa, índice gengival, profundidade de sondagem e nível de inserção no sítio-controle. Embora a quantidade de placa tenha diminuído, o sítio-teste permaneceu com sangramento a sondagem, não sofreu redução na profundidade de sondagem, mas verificou-se melhora no nível de inserção clínica. Apesar de não termos realizado a identificação dos microrganismos isolados dos sítios teste e controle, MOMBELLI et al. ${ }^{52}$, em 2000, verificaram que nos sítios com sangramento havia a presença de Prevotella intermedia/nigrescens, enquanto em bolsas profundas Porphyromonas gingivalis foi detectada, conforme observação feita por HAMLET et al. ${ }^{22}$, em 2001. Outra possível explicação para a presença de sangramento poderia estar associado com a capacidade dos periodontopatógenos invadir as células epiteliais e tecido conjuntivo subepitelial, pois a raspagem subgengival não erradicou $A$. actinomycetemcomitans, $P$. gingivalis, $P$. intermedia, B. forsythus e P. micros, conforme o descrito por RAMS; SLOTS $^{58}$, em 1996. O paciente 5, embora não tenha sofrido alteração nos índice de placa e índice gengival nos sítios teste e controle, apresentou redução na profundidade de sondagem e nível de inserção. Os pacientes 6 e 8 mostraram redução dos quatro parâmetros clínicos avaliados, em ambos os sítios, exceto o índice de placa do sítio teste do paciente 6 e o 
índice de placa do sítio controle do paciente $8(\mathrm{IPl}=1)$ que não sofreram alteração. O paciente 9 mostrou redução no índice de placa, índice gengival, profundidade de sondagem em ambos os sítios avaliados, entretanto somente houve melhora no nível de inserção do sítio teste. Todos os demais pacientes mostraram redução nos quatro parâmetros clínicos de ambos os sítios avaliados (Tabela 1). Assim, ambos os tratamentos proporcionaram melhora nos parâmetros clínicos avaliados, porém não houve diferença significante.

Em relação à avaliação radiográfica, JEFFCOAT et al. ${ }^{26}$, em 2000, constataram que a pastilha de clorexidina associado aos procedimentos de raspagem e alisamento radicular foi mais efetivo em manter osso alveolar após um período de nove meses. O mesmo resultado foi confirmado por PALCANIS et al. ${ }^{57}$, em 1997.

No entanto, CRUZ et al. ${ }^{7}$, em 2001, constataram que pacientes submetidos à terapia periodontal inicial e cirurgia com retalho mucoperiostal e que receberam a pastilha de clorexidina durante o procedimento cirúrgico mostraram eficiência clínica para a resolução do processo inflamatório, contudo sua utilização não representou benefício adicional quando comparado com a terapia convencional após um período de avaliação de três meses, fato que foi também observado em nosso estudo, onde foi feito o acompanhamento por 70 dias. Alguns trabalhos realizaram avaliações dos parâmetros clínicos após diferentes períodos, entretanto diferenças apresentam-se estatisticamente significantes entre os grupos avaliados e os resultados tornam-se mais evidentes após três e seis meses $^{21,39,68}$, sendo que alguns recomendam nove meses ${ }^{25,26,39,74}$.

Para a contagem das unidades formadoras de colônias $/ \mathrm{mL}$ de placa foram utilizados dois meios de cultura, BYC e CBRCA. Os valores médios 
e desvio padrão da contagem das UFC/mL de plac a entre os grupos teste e controle quando se utilizou o meio de cultura BYC (Tabela 5 e Figura 22) e o meio de cultura CBRCA (Tabela 9 e Figura 23) nos quatro períodos avaliados, mostraram que, após dez dias, houve redução em ambos os grupos quando comparados aos valores iniciais, porém o grupo controle mostrou maior redução. Após 40 e 70, dias observou-se que o grupo controle mostrou um aumento na contagem das UFC/mL de placa quando comparado ao valor observado após dez dias, entretanto esses valores permaneceram menores que o valor inicial. Quando se utilizou o meio BYC, o grupo teste mostrou redução após 40 dias em relação ao valor observado após dez dias, no entanto, verificou-se que após 70 dias a média da contagem do número de $\mathrm{UFC} / \mathrm{mL}$ de placa apresentou valor superior aos valores observados após dez e 40 dias e continuou inferior ao valor inicial. Quando se utilizou o meio CRBCA, o valor do grupo teste aumentou após 40 e 70 dias em relação ao valor observado após dez dias, mas verificou-se que esses valores permaneceram inferiores ao valor inicial.

Foi observado que somente em dois sítios-controle (pacientes 2 e 5) houve aumento na contagem das UFC/mL de placa após 40 e 70 dias da contagem inicial e que somente em um sítio-teste (paciente 5) houve aumento após 70 dias da contagem inicial quando se utilizou o meio BYC (Tabela 4). Os parâmetros clínicos avaliados do paciente 2 no sítio-controle mostraram melhora 70 dias após o início do estudo, assim o aumento da contagem das $\mathrm{UFC} / \mathrm{mL} 70$ dias após a contagem inicial provavelmente deve-se a recolonização de bactérias não periodontopatogênicas. $\mathrm{O}$ aumento de $\mathrm{UFC} / \mathrm{mL}$ de ambos os sítios do paciente 5 após 70 dias da contagem inicial parece estar relacionado com a manutenção de bactérias periodontopatogênicas, uma vez que ambos os sítios permaneceram com 
sangramento à sondagem 70 dias após a avaliação inicial, confirmando os dados obtidos por RAMS; SLOT ${ }^{58}$, em 1996.

Quando se utilizou o meio CBRCA, observou-se que somente um sítio-controle (paciente 5) mostrou aumento em relação a contagem inicial e que somente em dois sítios-teste (pacientes 3 e 5) verificou-se aumento da contagem das UFC/mL após 70 dias da contagem inicial (Tabela 8) . O aumento da contagem das UFC/mL dos sítios-teste dos pacientes 3 e 5, provavelmente foi decorrente da permanência ou aumento de bactérias periodontopatogênicas, visto que o índice gengival não sofreu redução. MAGNUSSON et al. ${ }^{47}$, em 1984, afirmaram que a recolonização da microbiota subgengival após raspagem e alisamento radicular pode ocorrer lentamente após vários meses, sendo que algumas espécies bacterianas recolonizam bolsas periodontais profundas após 140 a 224 dias, presumivelmente devido à presença de placa bacteriana residual não removida pelo debridamento mecânico. No presente trabalho, foi verificado que após 70 dias estava evidente a recolonização de microrganismos nos sítios, independente do tipo de tratamento empregado, porém apesar de não termos realizado a identificação destes microrganismos, podemos sugerir que naqueles sítios nos quais ocorreu melhora no índice gengival os microrganismos presentes foram provavelmente não periodontopatogênicos e nos sítios que continuaram com sangramento à sondagem provavelmente ocorreu a recolonização por periodontopatógenos.

A Porphyromonas gingivalis foi considerada como um periodontopatógeno por diversos autores ${ }^{2,9,11,13,19,20,22,35,52,55,59,61,62,66,76,79,80} \mathrm{e}$ KOJIMA; YASUI; ISHIKAWA ${ }^{35}$, em 1993, ao avaliarem o papel deste microrganismo na patogenia da doença periodontal, verificaram que sua 
detecção foi extremamente baixa em bolsas com profundidade de sondagem menor que $3 \mathrm{~mm}$, mas quando a profundidade de sondagem foi maior que $4 \mathrm{~mm}$ ou com sangramento à sondagem houve um aumento de 80\% na concentração dessas espécies bacterianas . Entretanto essa bactéria foi também detectada em sítios clinicamente saudáveis e não foi detectada em sítios doentes em alguns pacientes, indicando que sua presença é importante, mas não é o único responsável pela periodontite crônica. Essas observações foram confirmadas por ELLWOOD et $\mathrm{al}^{11}$, em 1997, que associaram a presença da $P$. gingivalis com a presença de cálculo subgengival, sangramento à sondagem e com profundidade de sondagem maior que $3 \mathrm{~mm}$. Dessa forma, é provável que esta bactéria associada a outros patógenos estivesse presente na maioria dos sítios avaliados em nossa pesquisa e que sua recolonização ocorreu naqueles sítios que continuaram com sangramento à sondagem 70 dias após a realização de ambos os tratamentos. Outras bactérias que também poderiam estar presentes nos sítios avaliados seria a Prevotella intermedia e o Fusobacterium nucleatum uma vez que ALPAGOT et al. ${ }^{2}$, em 1996, observaram que estes microrganismos estavam associados com a profundidade de sondagem. Além da presença dos fatores bacterianos, devemos levar em consideração a susceptibilidade do hospedeiro e as condições ambientais locais que aumentam a susceptibilidade, conforme salientado por WOLFF; DAHLÈN; AEPPLI ${ }^{79}$, em 1994.

Além da $P$. gingivalis, $P$. intermedia, e $F$. nucleatum, GENCO et al. ${ }^{13}$, em 1998, ressaltaram a participação de outros microrganismos na etiologia da doença periodontal, como A. actinomycetemcomitans, $B$. forsythus, Campylobacter rectus, Eubacterium nodatum, Peptostreptococcus micros, Treponema denticola, Eikenella corrodens, 
Pseudomonas, Selenomonas e Staphylococcus. A progressão da doença periodontal se deve em parte à resposta do hospedeiro e em parte à interação entre os membros da microbiota bucal, conforme o que foi descrito por GREENE ${ }^{17}$, em 1997; PAGE ${ }^{56}$, em 1998; SOCRANSKY et al. ${ }^{69}$, em 1999. A presença de microrganismos como Treponema socranskii, Treponema denticola e Porphyromonas gingivalis com a destruição periodontal, estando associados respectivamente a 89,2\%, 93,8\% e 95,3\% das amostras de placa subgengival de pacientes com periodontite crônica também foi enfatizada por TAKEUCHI et al. ${ }^{76}$, em 2001.

O efeito dos tratamentos comparados neste estudo (raspagem e alisamento radicular associados à colocação da pastilha de clorexidina ou somente raspagem e alisamento radicular) ao longo do tempo e nos diferentes sítios foi avaliado utilizando análise de variância a dois critérios (ANOVA) . Para o meio BYC (Tabela 6) houve diferença estatisticamente significante quanto ao tempo $(\mathrm{F}=14,20 ; \mathrm{p}<0,0001)$, porém não houve diferença estatisticamente significante quanto aos sítios teste e controle $(\mathrm{F}=$ $1,30 ; \mathrm{p}=0,28)$ e nem quanto a interação entre os dois sítios $(\mathrm{F}=2,05$; $\mathrm{p}=0,13)$.

Também quando utilizamos o meio CBRCA (Tabela 10) não verificou -se diferença estatisticamente sign ificante quanto aos sítios teste e controle $(\mathrm{F}=0,77 ; \mathrm{p}=0,40)$ e nem quanto à interação entre os dois critérios $(\mathrm{F}=2,13 ; \mathrm{p}=0,12)$, mas observamos diferença estatisticamente significante em relação ao tempo de observação $(\mathrm{F}=11,93 ; \mathrm{p}<0,0001)$. Dessa forma, verificamos não haver diferenças estatisticamente significante quando comparamos as duas modalidades de tratamento (grupo teste e grupo controle). Estes resultados estão condizentes com os resultados 
encontrados por DANESHMAND et al. ${ }^{8}$, em 2000, que não encontraram diferenças estatisticamente significantes na comparação dos sítios que receberam o PerioChip ${ }^{\circledR}$ após a raspagem e alisamento radicular e aqueles que receberam somente raspagem e alisamento radicular. Dessa forma, ficou evidente em nosso estudo que a raspagem e alisamento radicular constituem a principal forma de tratamento para as doenças periodontais, estando em consenso com a afirmação de KALDAHL; KALKWARF; PATIL $^{28}$, em 1993, segundo a qual os efeitos clínicos da terapia mecânica indicam haver redução do índice gengival, profundidade de sondagem e melhora nos níveis de inserção.

Os quatro períodos de análise microbiológica foram comparados através do teste de Tukey para o meio BYC (Tabela 7) e observou-se diferenças estatisticamente significantes entre o exame inicial e aos dez dias e 40 dias e entre os exames aos dez e 70 dias, mas não houveram diferenças estatisticamente significantes quando se compararam os exames iniciais e aos 70 dias, aos dez dias e 40 dias e aos 40 e 70 dias.

Resultados semelhantes foram observados quando se utilizou o meio CBRCA, exceto por ter mostrado diferença estatisticamente significante quando se compararam início e 70 dias (Tabela 11). Observouse que, após 70 dias, a contagem UFC/mL de placa encontrava-se inferior, porém ocorreu um aumento do número de $\mathrm{UFC} / \mathrm{mL}$ de placa em relação aos valores da contagem inicial, indicando que, provavelmente, tenha ocorrido uma substituição dos tipos de microrganismos periodontopatogênicos por uma microbiota menos patogênica, uma vez que os parâmetros clínicos avaliados foram mais favoráveis à saúde dos tecidos periodontais quando comparados ao início do estudo. Verificamos uma melhora no nível de inserção em ambos os grupos analisados, o que vem 
de encontro ao estudo realizado por MAC FARLANE et al. ${ }^{44}$, em 1988, que verificaram que a mudança no nível de inserção não foi dependente da porcentagem inicial de microrganismos como espiroquetas e bacteróides.

Além disso, SBORDONE et al. ${ }^{59}$, em 1990, ao avaliarem o padrão de recolonização da microbiota subgengival em oito pacientes com periodontite do adulto submetidos a uma sessão de raspagem e alisamento radicular e não realização de instrução de higiene bucal, verificaram que, após 60 dias não ocorreram mudanças marcantes em relação ao índice de placa, índice gengival e profundidade de sondagem, bem como observaram que bactérias anaeróbias como Fusobacterium nucleatum, Porphyromonas gingivalis e Provotella intermedia foram prevalentes antes e após os procedimentos de raspagem e alisamento radicular, portanto uma sessão de raspagem e alisamento radicular e não realização de instrução de higiene bucal foram insuficientes para manter a microbiota subgengival compatível com a saúde periodontal. Todos os pacientes que participaram de nosso estudo receberam instrução de higiene bucal, visto que o controle de placa supragengival é de fundamental importância para evitar a recolonização da microbiota subgengival. $O$ fato de nenhum paciente ser fumante também pode ter colaborado na obtenção de resultados favoráveis, conforme verificaram PALCANIS et al. ${ }^{57}$, em 1997, em que dos indivíduos que apresentaram perda óssea, 39\% eram fumantes.

Ao compararmos os dois meios utilizados no presente estudo, BYC e CBRCA, através do teste de correlação, observamos uma correlação $(\mathrm{r}=0,93)$ positiva o que significa que ambos os meios foram adequados para a contagem das UFC/mL de placa (Figura 24).

Os resultados deste estudo sugerem que o emprego da pastilha de clorexidina associada aos procedimentos de raspagem e alisamento 
radicular não promove benefícios clínicos e microbiológicos adicionais quando comparado somente à terapia mecânica periodontal, entretanto estes resultados devem ser entendidos com cautela, pois a amostra foi somente de dez pacientes e o período de acompanhamento foi de apenas 70 dias. 


\section{CONCLUSÕES}

Os resultados obtidos a partir das avaliações clínica e microbiológica de pacientes com periodontite crônica nos quais foram comparados a raspagem e alisamento radicular (grupo controle) e raspagem e alisamento radicular associados à colocação da pastilha de clorexidina (grupo teste), permitiram concluir:

1- O tratamento de bolsa periodontais de 5 a $8 \mathrm{~mm}$ através de raspagem e alisamento radicular acompanhado ou não pela inserção das pastilhas contendo clorexidina é efetivo na redução dos parâmetros clínicos da doença periodontal, índice de placa, índice gengival, profundidade de sondagem e nível de inserção clínica;

2- A utilização da pastilha de clorexidina associada à instrumentação mecânica não representa benefício adicional quando comparado à terapia mecânica isolada;

3- A correlação dos resultados clínicos com os microbiológicos sugere uma recolonização da microbiota subgengival após 70 dias por microrganismos predominantemente não periodontopatogênicos; 
4- Os meios de cultura, BYC e CBRCA, foram adequados para a contagem das UFC/mL de placa, não existindo diferenças na utilização para essa finalidade. 
ANEXO A - Carta de informação ao paciente sobre os procedimentos da pesquisa

\author{
UNIVERSIDADE DE SÃO PAULO \\ FACULDADE DE ODONTOLOGIA DE BAURU \\ COMITÊ DE ÉTICA EM PESQUISA
}

CARTA DE INFORMAÇÃO AO PACIENTE

\title{
Prezado Sr.(a)
}

A pesquisa Avaliação do periochip na microbiota subgengival de pacientes portadores de periodontite de adulto constitui o trabalho de dissertação de mestrado do C.D. Fábio Luis Moura Lima, sob orientação do Prof. Dr. Sérgio Aparecido Torres e será desenvolvida nas dependências físicas da Disciplina de Periodontia FOB-USP.

Há evidências de que algumas bactérias causam a doença periodontal em seres humanos. Esses microrganismos usam as estruturas de proteção e sustentação dos dentes como fatores alimentares e o metabolismo bacteriano resulta na formação de subprodutos que potencializam a destruição dos tecidos gengivais. Os dentes parecem mais suscetíveis à infecção por essas bactérias quando as medidas de higiene bucal permitem o acúmulo de placa na superfícies dos dentes, propiciando o desenvolvimento destes microrganismos patogênicos. Pesquisas demonstraram que as medidas de higiene bucal realizadas pelo paciente, quando associadas com o tratamento odontológico regular e preventivo de raspagem e alisamento radicular, houve uma demora ou o impediu a progressão e difusão dessa infecção das gengivas.

Gostaríamos de avaliar se o emprego de um dispositivo que libera lentamente o antisséptico - clorexidina no interior dos sítios que apresentam a 
doença periodontal, irá reduzir a presença das principais associadas com o aparecimento dessa infecção e se essa observação pode ser repetida, conforme outros dados obtidos em pesquisa clínicas. Em particular, desejamos verificar se a colocação deste dispositivo reduzirá a presença destas bactérias e avaliar a aceitação e cooperação dos pacientes quando da indicação deste procedimento, uma vez que o mesmo pode evitar a terapia cirúrgica. Teremos que colher placa subgengival dos pacientes incluídos na pesquisa. Este procedimento não traz desconforto, e será realizado pelo pesquisador responsável .

Todos os participantes irão receber informações sobre as técnicas de escovação e do uso do fio dental, todo tratamento odontológico necessário para remover a placa dentária subgengival presente em seus dentes. Esse tratamento será gratuito e executado no departamento de Periodontia da Faculdade de Odontologia de Bauru - USP. A assistência e acompanhamento estará sob a responsabilidade da pesquisador.

Somos de opinião que o que vamos realizar (raspagem e alisamento radicular para a limpeza dos dentes) é seguro e benéfico para os participantes. Se, em qualquer momento achar que o tratamento está tendo um efeito contrário (ruim ou desfavorável), o mesmo será suspenso.

$\mathrm{Na}$ eventualidade de ocorrência de danos decorrentes da pesquisa, os pesquisadores são responsáveis pela assistência integral necessária à promoção do reparo de tais danos.

Se nosso tratamento tiver êxito, os participantes poderão esperar menos problemas periodontais do que normalmente teriam. Se desejar participar deste estudo, queira por favor ler os parágrafos seguintes e assinar em baixo. 
ANEXO B - Termo de consentimento livre e esclarecido para participar da pesquisa

\author{
UNIVERSIDADE DE SÃO PAULO \\ FACULDADE DE ODONTOLOGIA DE BAURU \\ COMITÊ DE ÉTICA EM PESQUISA
}

\title{
TERMO DE CONSENTIMENTO LIVRE E ESCLARECIDO
}

Pelo presente instrumento que atende às exigências legais, o (a) senhor (a). portador (a)

da cédula de identidade de $\mathrm{n}^{\mathrm{o}}$. SSP/SP, após leitura minuciosa da CARTA DE INFORMAÇÃO AO PACIENTE, devidamente explicada pelo (s) profissional em seus mínimos detalhes, ciente dos serviços e procedimentos aos quais será submetido (a), não restando quaisquer dúvidas a respeito do lido e do explicado, firma seu CONSENTIMETO LIVRE E ESCLARECIDO em concordância em participar da pesquisa proposta no que lhe é cabível, conforme a CARTA DE INFORMAÇÃO AO PACIENTE.

Fica claro que o paciente ou seu representante legal, podem a qualquer momento retirar seu CONSENTIMENTO LIVRE E ESCLARECIDO e deixar de participar do estudo alvo da pesquisa e ciente que todo trabalho realizado torna-se informação confidencial guardada por força do sigilo profissional (Art. $9^{\circ}$ do Código de Ética Odontológica).

Por estarem entendidos e conformados, assinam o presente termo.

Bauru - SP,

Paciente 
ANEXO C - Relatório de aprovação pelo Comitê de Ética em Pesquisa

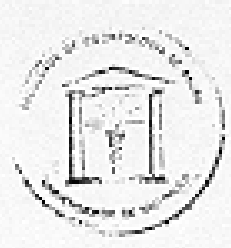

\author{
Universidade de São Paulo \\ Faculdade de Odontologia de Bauru
}

Al. Dr. Octívio Pinleeiro Brisolla, 9-75 - Bauru-SP - CEP 17012-901 - C.P. 73

PABX (0XX14)235-8000 - FAX (0XX14)223-4679

Comile de Érice em Pesquise

Of. $n^{\circ}$ CEPJOSOZFOB

Bauru, 15 de agosto de 2002

Senhor Professor,

O projelo de pesquisa encaminhado a este Comitè de Ética em Pesquisa em Seres Humanos, denominado "Avaliaçäo do Periochip na microbiota subgengival de pacientes portadores de periodontite do adulto", de autoria do C.D. Fábio Luis Moura Lima, desenvolvido sob a sua crientaçăo, foi envado ao relator para avaliação.

aprovando o preuniáo de 29 de junho de 2000 o parecer do relator, éticas pendentes

Informamos que apos o envio do trabalho concluido, este Comitè enviarà o parecer final, que será utilizado para publicaçāo do trabalho.

Atenciosamente,

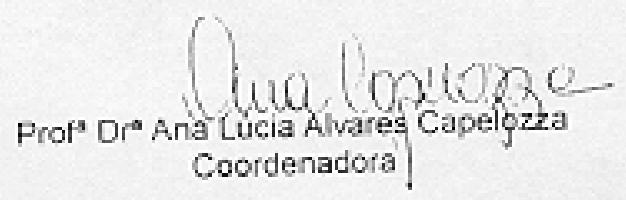

$\| m^{\circ}$ Sr. Prof. Dr. Sérgio Aparecido Torres

DD. Docente do Departamento de Ciências Biológicas (Microbiologia) 
ANEXO D - Modelo da ficha clínica para registro dos parâmetros periodontais

\section{EXAME PERIODONTAL}

Responsivel pels exank:

DATA:

VESTIBULAR LINGUAL INDICI: IND.GENGIVAL

DENTE
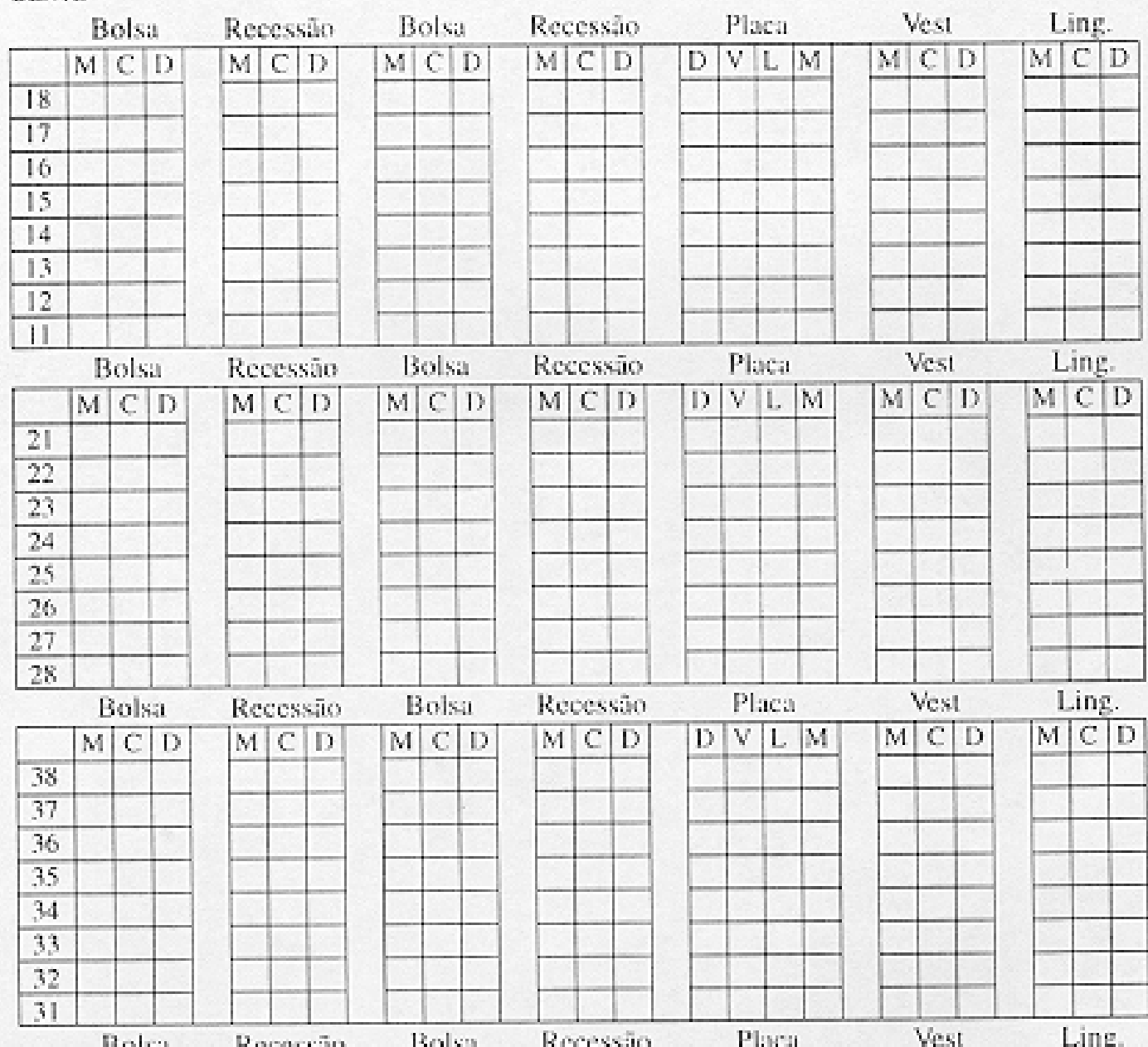

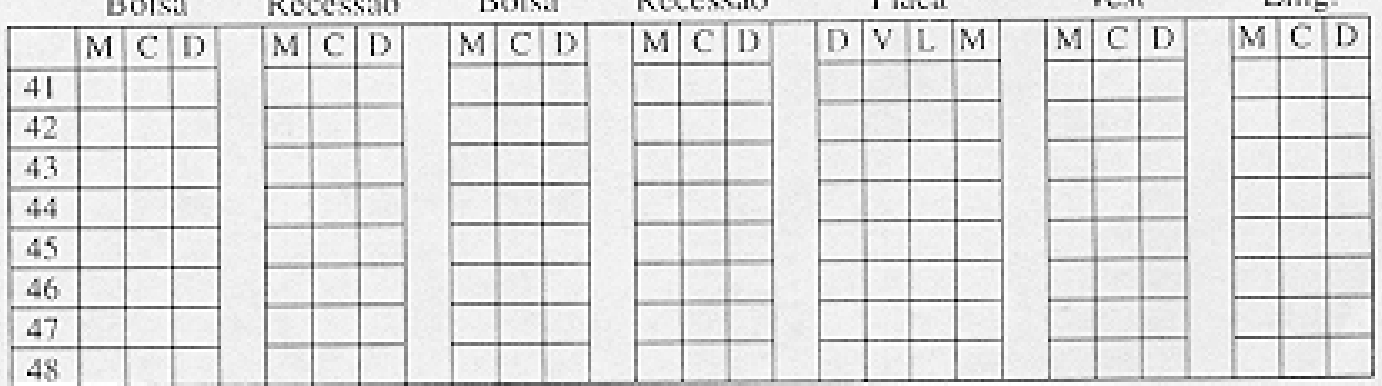




\section{REFERÊNCIAS BIBLIOGRÁFICAS *}

$1-\mathrm{ADDY}, \mathrm{M}$ et al. Use of antimicrobial containing acrylic strips in the treatment of chronic periodontal disease: a three month follow-up study. J. Periodont.,v.59, n.9, p.557-64, Sept. 1988.

2 - ALPAGOT, T. et al. Risk indicators for periodontal disease in a racially diverse urban population. J. clin. Periodont.,v.23, n.11, p.982-8, Nov. 1996.

3 - ARMITAGE, G. C. Development of a classification system for periodontal diseases and conditions. Annals Periodont., v.4, n.1, p.1-5, Dec. 1999.

4 - BAHN, A. N. Microbial potential in the etiology of periodontal disease. J. Periodont., v.41, n.11, p.603-10, Nov. 1970.

5 - CIANCIO, S.G. Site specific delivery of antimicrobial agents for periodontal disease. Gen. Dent., v.47, n.2, p. 172-8, Mar./Apr. 1999.

6-CIANCIO, S.G. Local delivery of chlorhexidine. Comp. Continuing Educ. Dent., v.20, n.5, p.427-32, May 1999.

7 - CRUZ, G. A. de. et al. Utilização de dispositivo de liberação lenta de clorexidina em pacientes com periodontite crônica. J. bras. Endo/Perio, v.2, n.5, p. 171-5, apr./jun 2001.

8 -DANESHMAND, $\mathrm{N}$. et al. Effect of periochip treatment on the subgingival microbiota. J. Periodont.,v.71, n.11, p.1806-7, Nov. 2000 .

\footnotetext{
* Normas recomendadas para uso no âmbito da Universidade de São Paulo, com base no documento:"Referências Bibliográficas: exemplos" emanado do Conselho Supervisor do Sistema Integrado de Bibliotecas da USP, em reunião de 20 de setembro de 1990.
} 
9 - DEVEAUX, E. et al. Survival of Prevotella intermedia (Bacteroides intermedius) in transport media. J. Biol. Buccale, v.19, n.3, p.241-6, Sept. 1991.

10 - EBERSOLE, J. L. ; TAUBMAN, M. A. The protective nature of host responses in periodontal diseases. Periodontology 2000, v.5, p.11241, 1994.

11 - ELLWOOD, R. Prevalence of suspected periodontal pathogens indentified using ELISA in adolescents of differing ethnic origins. $\mathbf{J}$. clin. Periodont., v.24, n.3, p.141-5, Mar. 1997.

12- FINKELMAN, R.D.; WILLIAMS, R.C. Local delivery of chemotherapeutic agentes in periodontal therapy: has its time arrived? J. clin. Periodont., v.25, n.11, p.943-6, Nov. 1998.

13-GENCO, R. et al. Periodontal diseases: pathogenesis and microbial factors. J. Amer. dent. Ass., v. 129, p. 58-62, Sept. 1998. Supplement.

14-GERSDORF, H. et al. Identification of Bacteroides forsythus in subgingival plaque from patients with advanced periodontitis. J. clin. Microbiol., v.31, n. 4, p.941-6, Apr. 1993.

15- GJERMO, P. Chlorhexidine and related compounds. J. dent. Res., v.68, p.1602-8, Nov. 1989. Special Issue.

16- GOODSON, J. M. Pharmacokinetic principles controlling efficacy of oral therapy. J. dent. Res., v.68, p.1625-32, Nov. 1989. Special Issue.

17- GREENE, P. R. Locally delivered antimicrobials in periodontal theraphy. Dent. Update, v.24, p.204-7, June 1997.

18- GREENSTEIN, G.; BERMAN, C.; JAFFIN, R. Chlorhexidine: an adjunct to periodontal therapy. J. Periodont., v.57, n.6, p.370-7, June 1986.

19- GROSSI, S. G. et al. Assessment of Risk for periodontal disease: I. risk indicators for attachment loss. J. Periodont., v. 65, n.3, p.260-7, Mar. 1994. 
20- GROSSI, S. G. et al. Assessment of Risk for periodontal disease: II.risk indicators for alveolar bone loss. J. Periodont. v. 66, n.1, p.23-9, Jan. 1995.

21-GOODSON, J. M. Pharmacokinetic principles controlling eficacy of oral therapy. J. dent. Res., v.68, p.1625-32, 1989 apud RAMS,T.E.; SLOTS, J. Local delivery of antimicrobial agents in the periodontal pocket. Periodontology 2000, v.10, p.139-59, Feb.1996.

22-HAMLET, S. M. et al. Distribution of Actinobacillus actinomycetemcomitans, Porphyromonas gingivalis and Prevotella intermedia in an Australian population. J. clin. Periodont., v.28, n.12, p.1163-71, Dec. 2001.

23-HEASMAN, P. A. et al. Local delivery of chlorhexidine gluconate (PerioChip $^{\mathrm{TM}}$ ) in periodontal maintenance patients. J. clin. Periodont. v.28, n.1, p.90-5, Jan. 2001.

24- JEFFCOAT, M. K. et al. Multicenter evaluation of a biodegradable chlorhexidine/gelatin chip for the treatment of adult periodontitis. J. dent. Res., v. 76, p. 152, 1997. /abstract n.1110/

25- JEFFCOAT, M.K. et al. Adjunctive use of a subgingival controlledrelease chlorhexidine chip reduces probing pocket depth and improves attachment level compared with scaling and root planning alone. J. Periodont., v.69, n.9 , p.989-97, Sept. 1998.

26- JEFFCOAT, M. K. et al. Use of a biodegradable chlorhexidine chip in the treatment of adult periodontitis: clinical and radiographic findings. $\mathbf{J}$. Periodont., v.71, n.2, p.256-62, Feb. 2000.

27-JOLKOVSKY, D. L. et al. Clinical and microbiological effects of subgingival and gingival marginal irrigation with chlorhexidine gluconate. J. Periodont. v. 61, n.11, p. 663-9, Sept. 1990.

28- KALDAHL, W. B.; KALKWARF, K. L.; PATIL, K. D. A review of longitudinal studies that compared periodontal therapies. J. Periodont. v.64, n., p.243-53, Apr. 1993. 
29- KELSTRUP, J. ; THEILADE, E. Microbes and periodontal disease. J. clin. Periodont., v.1, n.1, p.15-35, 1974.

30- KILLOY, W.J. Chemical treatment of periodontitis: local delivery of antimicrobials. Int. dent. J., v.48, n.3, p.305-15, June 1998. Supplement 1.

31- KILLOY, W.J. The use of local-delivered chlorhexidine in the treatment of periodontitis: clinical results. J. clin. Periodont., v.25, n.11, p.9538, Nov. 1998.

32- KILLOY, W.J. Assessing the effectiveness of locally delivered chlorhexidine in the treatment of periodontitis. J. Amer. dent. Ass., v.130, n.4, p.567-70, Apr. 1999.

33-KILlOY, W.J.; POLSON, A.M. Controlled local delivery of antimicrobials in the treatment of periodontitis. Dent. Clin. N. Amer., v.42, n.2, p.263-83, Apr. 1998.

34- KILLOY, W.J.; SAIKI,S.M. A new horizon for the dental hygienist: controlled local delivery of antimicrobial. J. dent. Hyg., v.73, n.2, p.84-92, Spring 1999.

35- KOJIMA, T.; YASUI, S.; ISHIKAWA, I. Distribution of Porphyromonas gingivalis in adult periodontitis patients. J. Periodont., v.64, n.12, p.1231-7, Dec. 1993.

36- KORNMAN, K.S. Agentes antimicrobianos tópicos: princípios gerais e sistemas de fornecimento. In: NEWMAN, M.; KORNMAN, K. O uso de antibióticos e antimicrobianos na prática odontológica. São Paulo, Quintessence, c1997. Cap.6, p.89-97.

37- LINDHE, J.; LILJENBERG, B; LISTGARTEN, M. Some microbiological and histopathological features of periodontal diseases in man. $\mathbf{J}$. Periodont., v.51, n.5, p. 264-9, May 1980.

38- LINDHE, J.; HAMP, S.E.; LÖE, H. Experimental periodontitis in the Beagle dog. J. Periodont. Res., v.8, n.1, p.1-10, 1973. 
39- LISSOVOY, G. et al. The cost-effectiveness of a new chlorhexidine delivery system in the treatment of adult periodontitis. J. Amer. dent. Ass., v.130, n.6, p.855-62, June 1999.

40- LÖE, $\mathrm{H}$. The gingival index, the plaque index and retention index systems.

J. Periodont., v.38, n.6, p.610-6, Nov./Dec. 1967. Supplement.

41- LÖE, H.; THEILADE, E.; JENSEN, S.B. Experimental gingivitis in man. J. Periodont., v.36, p.177-87, Sept. 1965.

42- LÖE, H. et al. Experimental gingivitis in man. III. The influence of antibiotics on gingival plaque development. J. Periodont. Res.,v.2, n.4, p.282-9, 1967.

43-MACALPINE, R. et al. Antimicrobial irrigation of deep pockets to supplement oral hygiene instruction and root debridement. J. clin. Periodont., v.12, p.568-72,1985.

44-MACFARLANE, T. W. et al. Longitudinal study of untreated periodontitis: (II). microbiological findings. J. clin. Periodont., v.15, n.5, p.331-7, 1988 .

45-MACNEILL, S.R. et al. The time and ease of placement of the chlorhexidine chip local delivery system. Comp. Continuing Educ. Dent., v.19, n.11, p.1158-67, Nov. 1998.

46- MAGNUSSON, I. Local delivery of antimicrobial agents for the treatment of periodontitis. Comp. Continuing Educ. Dent., v.19, n.10, p.953-6, Oct. 1998.

47-MAGNUSSON, I. et al. Recolonization of a subgingival microbiota following scaling in deep pockets. J. clin. Periodont., v.11, n..3, p.193-207, Mar 1984.

48- MAIDEN, M. F. J. et al. Detection of high-risk groups and individuals for periodontal diseases: laboratory markers based on the microbiological analysis of subgingival plaque. J. clin. Periodont., v.17, n.1, p.1-13, Jan. 1990.

49- MARSH, P. D. The significance of maintaining the stability of the natural microflora of the mouth. Brit. dent. J, v.171, n.21, Sept. 1991. 
50- MARSH, P. D. Microbiological aspects of the chemical control of plaque and gingivitis. J. dent. Res., v.71, n.71, p.1431-8, July 1992.

51- MARSH, P.D.; BRADSHAW, D.J. Dental plaque as a biofilm. J. Indust. Microbiol., v.15, n.3, p.169-75, Sept.1995.

52- MOMBELLI, A. et al. Persistence patterns of Porphyromonas gingivalis, Prevotella intermedia/nigrescens and Actinobacillus actinomycetemcomitans after mechanical therapy of periodontal disease. J. Periodont., v.71, n.3, p.403-9, Mar. 2000.

53- MOORE, W.E. Microbiology of periodontal disease. J. Periodont. Res., v.22, n.5, p.335-53, Sept.1987.

54- MOORE, L.V.H. et al. Bateriology of human gengivitis. J. dent. Res., v.66, n.5, p.989-95, 1987.

55- PAGE, R. C. Current understanding of the aetiology and progression of periodontal disease. Int. dent. J., v. 36, n.3, p. 153-61, Sept. 1986.

56- PAGE, R. C. Periodontal diseases: a new paradigm. J. dent. Educ., v.62, n.10, p.812-21, Oct. 1998.

57- PALCANIS, K. et al. A biodegradable chlorhexidine/gelatin chip for the treatment of adult periodontitis: effect on alveolar bone. J. dent. Res., v.76, p.152, 1997. / abstract n.1111/

58-RAMS,T.E.; SLOTS, J. Local delivery of antimicrobial agents in the periodontal pocket. Periodontology 2000, v.10, p.139-59, Feb.1996.

59-SBORDONE, L. et al. Recolonization of the subgingival microflora after scaling and root planning in human periodontitis. J. Periodont., v.61, n.9, p.579-84, Sept. 1990.

60- SILNESS, J; LÖE, H;. Periodontal disease in pregnancy. II. Correlation between oral hygiene and periodontal condition. Acta odont. scand., v.22, p.121-35, 1964. 
61-SLOTS, J.; DAHLÉ, G. Subgingival microorganisms and bacterial virulence factors in periodontitis. Scand. J. dent. Res., v.93, n.2, p. 119-27, Apr. 1985.

62-SLOTS, J.; GENCO, R. J. Microbial patogenicity. Black pigmented bacteroides species, capnocytophaga species and Actinobacillus actinomycetemcomitans in human periodontal disease: virulence factors in colonization, survival,and tissue destrution. J. dent. Res., v.63, n.3, p. 412-21, Mar. 1984.

63-SNYDERMAN, R. Role for endotoxin and complement in periodontal tissue destruction. J. dent. Res.,v.51, n.2, p.356-61, Apr. 1972.

64-SOCRANSKY, S. S. Relationship of bacteria to the etiology of periodontal disease. J. dent. Res., v.49, n.2, p. 203-22, Mar./Apr. 1970. Supplement.

65- SOCRANSKY, S. S. Microbiology of periodontal disease - present status and future considerations. J. Periodont.,v.48, n.9, p.497-504, Sept. 1977.

66-SOCRANSKY, S. S.; HAFFAJEE, A. D. The bacterial etiology of destructive periodontal disease: current concepts. J. Periodont., v.63, n.4, p.322-31, Apr. 1992. Supplement.

67- SOCRANSKY, S. S.; HAFFAJEE, A. D. Evidence of bacterial etiology: a historical perspective. Periodontology 2000, v.5, p.7-25, 1994.

68-SOCRANSKY, S.S.; HAFFAJEE, A.D. Microbiologia da doença periodontal. In: 34-LINDHE, J. Tratado de periodontia clínica e implantodontia oral. 3.ed. Rio de Janeiro, Guanabara Koogan, c1999. Cap.4, p.92-126.

69-SOCRANSKY, S. S. et al. Ecological considerations in the treatment of Actinobacillus actinomycetemcomitans and Porphyromonas gingivalis periodontal infections. Periodontology 2000, v.20, p.341-62, 1999.

70- SOSKOLNE, W.A. et al. Sustained local delivery of chlorhexidine in the treatment of periodontitis: a multi-center study. J. Periodont., v.68, n.1, p.32-38, Jan. 1997. 
71-SOSKOLNE, W.A. et al. An in vivo study of the chlorhexidine release profile of the periochip ${ }^{\mathrm{TM}}$ in the gingival crevicular fluid, plasma and urine. J. clin. Periodont., v.25, n.12, p.1017-21, Dec. 1998.

72- SORENSEN, E. Ergebn. Physiol., v.12, n.393, 1912. apud SOBER, H.A. Handbook of biochemistry: selected data for molecular biology. Cleveland, The Chemical Rubber, co 1968. p.J195-J198.

73-STABHOLZ, A.; SELA, M. N.; FRIEDMAN, M. Clinical and microbiological effects of sustained release chlorhexidine in periodontal pockets. J. clin. Periodont., v.13, n.8,p.783-8. Sept.1986.

74-STABHOLZ, A. et al. Using the Periochip in the treating adult periodontitis: an interim report. Comp. Continuing Educ. Dent., v. 21, n.4, p. 325-34, Apr. 2000.

75- STANLEY, A.; WILSON, M.; NEWMAN, H. N. The in vitro effects of chlorhexidine on subgingival plaque bacteria. J. clin. Periodont., v.16, n.4, p.259-64, Apr. 1989.

76- TAKEUCHI, Y. et al. Treponema socranskii, Treponema denticola, and Porphyromonas gingivalis are associated with severity of periodontal tissue destruction. J. Periodont., v.72, n.10, p.1354-63, Oct. 2001.

77- VAN PALENSTEIN HELDERMAN, W.H; WINKLER, K. C. Elective medium for the direct count of vibrio (campylobacter) fusobacteria, bacteroides, selenomonas and veillonella in the gingival crevice flora. J. Periodont. Res., v.10, n.4, p. 230-41, Oct. 1975.

78- WADE, W. G.; ADDY, M. In vitro activity of a chlorhexidine-containing mouthwash against subgingival bacteria. J. Periodont., v. 60, n.9 , p.521-5, Sept. 1989.

79-WOLFF, L.; DAHLÈN, G.; AEPPLI, D. Bacteria as risk markers for periodontitis. J. Periodont., v.65, n.5, p.498-510, May 1994. Supplement.

80- WOLFF, L. F. et al. Natural distribution of 5 bacteria associated with periodontal disease. J. clin. Periodont., v.20, n.10, p.699-706, Nov. 1993. 


\section{ABSTRACT \\ CLINICAL AND MICROBIOLOGICAL EVALUATION OF A SUBGINGIVAL CONTROLLED-RELEASE CHLORHEXIDINE IN PATIENTS WITH CHRONIC PERIODONTITIS}

Chronic periodontitis is a result of an infection in which specific pathogenic microorganisms are involved in its ethiology. Its is known that subgingival microflora, associated with some other local environmental factors and host response play a role in periodontal disease ethiology. The changes in the pathogens or their removal are essential to control the disease, as well as antimicrobial agents usage as a coadjutant to the mechanical therapy in the chronic periodontal disease, such as chlorhexidine. The efficacy of a controlled local delivery of chlorhexidine $(2.5 \mathrm{mg}$ ) as a coadjuvant therapy to scaling and root planing in the chronic periodontal disease treatment has been evaluated by this study. Ten subjects with bilateral periodontal pockets with probing depths 5 to $8 \mathrm{~mm}$ have been selected. Microbiological analyses were performed at the baseline point, 10, 40 and 70 days after the mechanical periodontal therapy (control site), and after the same treatment plus a chlorhexidine chip placement (test site). Clinical evaluation, assessed by plaque index, gingival index, gingival recession, probing depths and clinical attachment level, was done at the baseline point and after 70 days of treatment. No significant statistical differences among the sites have been observed. These results suggest that the chlorhexidine chip with mechanical therapy did not show any significant improvement when compared to gingival biofilm removal only. 